\title{
Experiences of people with Parkinson's disease and their views on physical activity interventions: a qualitative systematic review
}

\author{
Heather Hunter ${ }^{1,3} \cdot$ Christopher Lovegrove $^{2} \cdot$ Bernhard Haas $^{1} \cdot$ Jennifer Freeman ${ }^{1,3} \cdot$ Hilary Gunn ${ }^{1}$ \\ ${ }^{1}$ School of Health Professions, Plymouth University, Plymouth, United Kingdom, ${ }^{2}$ Royal Devon and Exeter NHS Trust, Exeter, United \\ Kingdom, and ${ }^{3}$ The University of Plymouth Centre for Innovations in Health and Social Care: a Joanna Briggs Institute Centre of Excellence
}

\section{A B S T R A C T}

Objective: The objective of the review was to synthesize the best available qualitative evidence on the experiences and preferences of people with Parkinson's disease for physical activity, their perceived motivators and barriers to engagement, as well as their views on support mechanisms and behavior change interventions designed to sustain participation.

Introduction: National and international guidelines recommend regular physical activity to improve health and wellbeing and to prevent disease. Research on Parkinson's disease indicates that physical activity programs can be beneficial in addressing both physical symptoms and overall wellbeing. However, despite recommendations, sustained engagement in regular physical activity among people with Parkinson's disease is limited. To promote physical activity it is important to understand their perspectives on this topic.

Inclusion criteria: This review considered studies that included a qualitative evaluation of the experiences and views of people with Parkinson's disease regarding physical activity and interventions designed to sustain participation.

Methods: The databases MEDLINE, Embase, CINAHL, AMED, Scopus and Web of Science, and unpublished studies in sources of grey literature (Google, OpenGrey, MedNar, Conference Paper Index, PQDT) were searched. Language limiters were restricted to English and dates ranged from the inception of the database to June 30, 2017. Two reviewers assessed studies that met the inclusion criteria independently, using the criteria of the Joanna Briggs Institute (JBI) Critical Appraisal Checklist for Qualitative Research. One reviewer completed data extraction using the standardized qualitative data extraction tool. This was checked for accuracy by a second reviewer. The qualitative research findings were pooled using JBI methodology. The JBI process of meta-aggregation was used to identify categories and synthesized findings.

Results: Nineteen studies were included in this review following assessment of the methodological quality of each study. Two studies were excluded after the methodological review as the findings were not supported by illustrations of the participant voice. Subsequently, 105 findings were extracted and aggregated into 20 categories and eight synthesized findings. Methodological quality was variable and overall confidence in the findings was determined to be low.

Conclusion: This review revealed that people with Parkinson's disease viewed physical activity as an enjoyable and positive experience, which aided with control of their symptoms and enhanced their wellbeing and quality of life. Aligned with evidence from older adults and those with long-term conditions, this review identified disease presentation, intrapersonal characteristics, program design, external support and the social and physical environment as contributory factors which influenced the ability of people with Parkinson's disease to sustain engagement in physical activity. The unique contribution and weighting of these factors will affect an individual's participation in physical activity. This review provides important insights into the challenges of undertaking physical activity while living with a progressive and fluctuating disease. These qualitative findings give healthcare providers an insight into

Correspondence: Heather Hunter, heather.hunter@plymouth.ac.uk

There is no conflict of interest in this project.

DOI: 10.11124/JBISRIR-2017-003901

JBI Database of Systematic Reviews and Implementation Reports

(C) 2019 THE JOANNA BRIGGS INSTITUTE 
the views and experiences of people with Parkinson's disease and are useful, alongside quantitative evidence of effectiveness, for the design of physical activity programs that are meaningful for this population. However, a limitation of this review is that it does not address the views and experiences of people with Parkinson's disease who are inactive.

Keywords Experiences; Parkinson's disease; participation; physical activity; qualitative

JBI Database System Rev Implement Rep 2019; 17(4):548-613.

\section{Summary of Findings}

$T$ he ConQual approach ${ }^{1}$ was used to assess and report confidence in the results of this qualitative systematic review. The 19 papers included in this review were all qualitative studies and were assessed for dependability based upon the number of 'yes' answers on the dependability score, with high grade awarded to studies that had four to five yes scores, moderate grade to those with two to three 'yes' scores and a low grade for a zero to one 'yes' score. See Appendix I for Dependability score for each qualitative research paper. Credibility of the findings was graded at three levels: those that could not be challenged were graded unequivocal (U), those that could be challenged were graded credible $(\mathrm{C})$ and those that were not supported (NS). Only those findings graded as unequivocal or credible were extracted for data synthesis. See Appendix II for development of ConQual Score. The level of credibility of each finding was based on consensus between two reviewers.

\begin{tabular}{|c|c|c|c|c|c|}
\hline \multicolumn{6}{|c|}{ Experiences of people with Parkinson's disease and their views on physical activity interventions: a qualitative systematic review } \\
\hline \multicolumn{6}{|c|}{$\begin{array}{l}\text { Hunter H, Lovegrove C, Haas B, Freeman J, Gunn H. Experiences of people with Parkinson's disease and their views on physical activity interventions: a } \\
\text { qualitative systematic review. JBI Database System Rev Implement Rep 2019;17(4):548-613. }\end{array}$} \\
\hline Synthesized finding & $\begin{array}{l}\text { Type of } \\
\text { research }\end{array}$ & Dependability & Credibility & $\begin{array}{l}\text { Final ConQual } \\
\text { score }\end{array}$ & Comments \\
\hline $\begin{array}{l}\text { 1. Participating in physical activity is seen as positive; } \\
\text { participants report improvements in physical and psy- } \\
\text { chological function and symptom control. Participating } \\
\text { in physical activity leads to holistic changes, including a } \\
\text { sense of achievement, improved confidence and wellbe- } \\
\text { ing. }\end{array}$ & Qualitative & $\begin{array}{l}\text { Downgraded } 1 \\
\text { level }\end{array}$ & $\begin{array}{l}\text { Downgraded } \\
1 \text { level }\end{array}$ & Low & $\begin{array}{l}\text { Downgraded } 2 \text { levels due to } \\
\text { moderate dependability and } \\
\text { moderate credibility }\end{array}$ \\
\hline $\begin{array}{l}\text { 2. Parkinson's disease is perceived to impact on all } \\
\text { aspects of physical activity, with temporal fluctuation } \\
\text { in symptoms presenting both emotional and physical } \\
\text { challenges. Changes to the level and type of physical } \\
\text { activity and individual strategies are used to maximize } \\
\text { participation. }\end{array}$ & Qualitative & $\begin{array}{l}\text { Downgraded } 1 \\
\text { level }\end{array}$ & $\begin{array}{l}\text { Downgraded } \\
1 \text { level }\end{array}$ & Low & $\begin{array}{l}\text { Downgraded } 2 \text { levels due to } \\
\text { moderate dependability and } \\
\text { moderate credibility }\end{array}$ \\
\hline $\begin{array}{l}\text { 3. Participation in physical activity is highly individual, } \\
\text { with participants valuing activities which are perceived } \\
\text { as personally relevant and tailored to their needs and } \\
\text { preferences. Participant perceptions of physical activity } \\
\text { are affected by expectations and self-evaluation of } \\
\text { progress. }\end{array}$ & Qualitative & $\begin{array}{l}\text { Downgraded } 1 \\
\text { level }\end{array}$ & $\begin{array}{l}\text { Downgraded } \\
1 \text { level }\end{array}$ & Low & $\begin{array}{l}\text { Downgraded } 2 \text { levels due to } \\
\text { moderate dependability and } \\
\text { moderate credibility }\end{array}$ \\
\hline $\begin{array}{l}\text { 4. External factors can affect participants' experience of } \\
\text { physical activity. Involvement of family members/ } \\
\text { friends and use of music make sessions enjoyable and } \\
\text { increase wellbeing. Support from instructors to ensure } \\
\text { physical activity programs are structured and simple to } \\
\text { undertake, to explain the relevance of activities and to } \\
\text { support progression gives participants confidence and } \\
\text { enhances their participation. }\end{array}$ & Qualitative & $\begin{array}{l}\text { Downgraded } 1 \\
\text { level }\end{array}$ & $\begin{array}{l}\text { Downgraded } \\
1 \text { level }\end{array}$ & Low & $\begin{array}{l}\text { Downgraded } 2 \text { levels due to } \\
\text { moderate dependability and } \\
\text { moderate credibility }\end{array}$ \\
\hline $\begin{array}{l}\text { 5. A personal desire to maintain independence and a } \\
\text { belief that physical activity can slow deterioration are } \\
\text { driving forces for participation. Motivation is enhanced } \\
\text { by perceived improvement in symptoms and feelings of } \\
\text { accountability to oneself or others. }\end{array}$ & Qualitative & $\begin{array}{l}\text { Downgraded } 1 \\
\text { level }\end{array}$ & $\begin{array}{l}\text { Downgraded } \\
1 \text { level }\end{array}$ & Low & $\begin{array}{l}\text { Downgraded } 2 \text { levels due to } \\
\text { moderate dependability and } \\
\text { moderate credibility }\end{array}$ \\
\hline
\end{tabular}




\section{(Continued)}

Experiences of people with Parkinson's disease and their views on physical activity interventions: a qualitative systematic review

Hunter H, Lovegrove C, Haas B, Freeman J, Gunn H. Experiences of people with Parkinson's disease and their views on physical activity interventions: a qualitative systematic review. JBI Database System Rev Implement Rep 2019;17(4):548-613.

\begin{tabular}{|c|c|c|c|c|c|}
\hline Synthesized finding & $\begin{array}{l}\text { Type of } \\
\text { research }\end{array}$ & Dependability & Credibility & $\begin{array}{l}\text { Final ConQual } \\
\text { score }\end{array}$ & Comments \\
\hline $\begin{array}{l}\text { 6. Participants report that personal characteristics such } \\
\text { as exercise habit, information seeking, resilience, prob- } \\
\text { lem solving and interest in the activity are motivators } \\
\text { for engagement. However, lack of time, low outcome } \\
\text { expectations and cultural challenges are seen as bar- } \\
\text { riers. Comparisons with others can be a motivator or } \\
\text { barrier to engagement. }\end{array}$ & Qualitative & $\begin{array}{l}\text { Downgraded } 1 \\
\text { level }\end{array}$ & $\begin{array}{l}\text { Downgraded } \\
1 \text { level }\end{array}$ & Low & $\begin{array}{l}\text { Downgraded } 2 \text { levels due to } \\
\text { moderate dependability and } \\
\text { moderate credibility }\end{array}$ \\
\hline $\begin{array}{l}\text { 7. Difficulty obtaining an initial diagnosis, accessibility } \\
\text { of services, disease symptoms (both physical and psy- } \\
\text { chological) and severity all impact on the ability and } \\
\text { desire to undertake physical activity in people with } \\
\text { Parkinson's disease. }\end{array}$ & Qualitative & $\begin{array}{l}\text { Downgraded } 1 \\
\text { level }\end{array}$ & $\begin{array}{l}\text { Downgraded } \\
1 \text { level }\end{array}$ & Low & $\begin{array}{l}\text { Downgraded } 2 \text { levels due to } \\
\text { moderate dependability and } \\
\text { moderate credibility }\end{array}$ \\
\hline $\begin{array}{l}\text { 8. Participants report that group members, family, } \\
\text { friends and co-workers provide support for them to } \\
\text { initiate and sustain physical activity. }\end{array}$ & Qualitative & $\begin{array}{l}\text { Downgraded } 1 \\
\text { level }\end{array}$ & $\begin{array}{l}\text { Downgraded } \\
1 \text { level }\end{array}$ & Low & $\begin{array}{l}\text { Downgraded } 2 \text { levels due to } \\
\text { moderate dependability and } \\
\text { moderate credibility }\end{array}$ \\
\hline
\end{tabular}

\section{Introduction}

Parkinson's disease (PD) is the second most common neurodegenerative disease after Alzheimer's, ${ }^{2}$ with incidence increasing with age, affecting $1 \%$ of the population over 60 years and $4 \%$ over 80 years in industrialized countries. ${ }^{3}$ Parkinson's disease is associated with abnormal neuronal activity in the basal ganglia due to the loss of dopaminergic neurons in the substantia nigra. ${ }^{4}$ This produces the cardinal features of PD: difficulty in initiating movements (akinesia) as well as slowness and difficulty maintaining movement (bradykinesia), tremor and rigidity. ${ }^{5}$ At the onset, symptoms are normally unilateral but as the disease progresses bilateral symptoms present with significant disability. Non-motor symptoms include fatigue, ${ }^{6}$ anxiety and depression. ${ }^{7}$ Despite optimal medical management, the progressive nature of the disease often results in people with Parkinson's disease (pwPD) experiencing reduced function and mobility. ${ }^{8}$ Consequently, pwPD tend to adopt a sedentary lifestyle and demonstrate lower levels of physical activity (PA) than healthy peers., ${ }^{9,10}$ For example, a large study which compared the PA data of pwPD $(n=699)$ to controls $(n=1959)$ found that pwPD were on average $29 \%$ less active compared to age matched controls. ${ }^{9}$ Furthermore, Lana et al. found increased age, disease severity and inability to perform activities of daily living to be predictors of physical inactivity in pwPD. ${ }^{11}$
Physical activity is defined as "any bodily movement produced by skeletal muscles that results in the expenditure of energy". ${ }^{12(p .127)}$ This is an umbrella term for the sum of all activity undertaken throughout the day and can subdivided into:

- Leisure time physical activity (e.g. walking and swimming).

- Non-leisure physical activity (occupational and household).

- Exercise (e.g. aerobic, strengthening, flexibility) which is structured and repetitive and is specifically aimed at improving or maintaining physical fitness. ${ }^{12}$

There is substantial evidence to support the benefits of a range of interventions designed to reverse the sequelae of physical inactivity in pwPD. ${ }^{13-18}$ To date, programs have tended to be supervised exercise programs in institutional settings and have reported improvements in quality of life, improved ambulation, balance, strength, flexibility and cardiovascular fitness compared with those who did not exercise. ${ }^{13,14,16} \mathrm{~A}$ criticism of much of this research is that the interventions are time limited and highly supervised with follow-up limited to short term (three to six months). Therefore, it is difficult to determine if PA is sustained long term following an intervention. Results from research across a variety of populations ${ }^{19-21}$ suggests that a return to physical inactivity upon cessation of such interventions is a 
reality. This is likely to be the case for pwPD, unless strategies for the maintenance of long-term participation are developed.

More recently, an alternative approach to encourage sustained participation in PA is the use of "leisure-based" activities such as Tai Chi and dance, both of which have demonstrated improvements in balance and mobility. ${ }^{22-24}$ In a study which compared Tai Chi to a progressive resistance training program, at follow-up (three months later) pwPD who undertook Tai Chi had improved perceptions of health related benefits and showed greater probability of continued exercise behavior than the resistance-training group. ${ }^{25}$ "Dance for Parkinson's" groups view dance as being an alternative form of PA with an emphasis on the creative, social and artistic practice that may also help alleviate symptoms and improve quality of life. ${ }^{26}$ However, longterm studies that measure sustained participation are lacking, and the cost of attending dance classes have been identified as a barrier. ${ }^{27}$

Because PA activity is a complex and dynamic process involving an intricate series of behaviors, identification of the variables affecting uptake and sustained participation is difficult. ${ }^{28}$ Therefore, the views of pwPD concerning their preferences as well as motivators and barriers to PA would be helpful to ensure that programs meet the needs of the intended audience. Personal characteristics of pwPD have been shown to influence motivation to undertake PA. Research in pwPD has identified the importance of self-efficacy, education and age as significant factors associated with increased PA. ${ }^{29}$ Enabling factors which have been identified in the PD literature include provision of peer and/or family support via instrumental, (e.g., provision of transport and mutual participation), emotional (e.g., provision of encouragement through a variety of face-to-face and remote means), and informational mechanisms, (e.g., type of exercise that would be beneficial to their condition by health professional or fitness instructor). ${ }^{30}$

Changing health behavior in terms of moving from a sedentary lifestyle to one that is physically active is both a complex and challenging process, particularly as the success of many rehabilitation programs requires both attendance at structured sessions and adherence to unsupervised home-based exercises. ${ }^{31}$ Simply informing people about the benefits of PA has been shown to be inadequate in sustaining behavioral change, ${ }^{31,32}$ leading to the development of behavioral change interventions in a number of long-term conditions. Studies evaluating their effectiveness have shown mixed results, ${ }^{20,33,34}$ highlighting the need to develop an understanding of service users' experiences and perceptions of these interventions in order to inform which specific aspects should be incorporated into PD specific programs.

In the context of this systematic review, behavior change interventions were defined as any psychology-based interventions (used alone or in combination with other interventions, such as exercise therapy) aimed directly or indirectly at behavior change with regard to level of PA participation or change in perceived physical function. Such interventions include goal setting, cognitive re-structuring and motivational interviewing. ${ }^{31}$

In order to facilitate behavioral change in pwPD, disease-specific coaching and counseling may be needed. ${ }^{35}$ The effect of the addition of behavior change interventions (goal setting, coaching and use of activity monitor to provide feedback) was studied in a multi-faceted PA program in pwPD over a two-year period. ${ }^{36}$ Results identified increased PA in almost all sub groups of pwPD (grouped by gender, activity level and disease severity), ${ }^{36}$ however, the overall time spent on physical activities (primary outcome measure) did not change, ${ }^{37}$ thereby illustrating the challenges of facilitating behavior change in pwPD. The effect of a daily interaction with a virtual exercise coach (five minutes a day) to encourage an increase in walking (measured by a pedometer) was studied in pwPD. Coaching included discussing progress with shortand long-term goals and positive reinforcement with joint problem solving to overcome barriers. Results after one month demonstrated an excellent retention rate in the walking program and improvements in objective measures of gait. ${ }^{38}$ However, the main limitation was that the trial only lasted for one month and it is unknown whether pwPD would maintain their walking program long-term and whether behavior change had occurred. The mixed results illustrate the challenges for changing health behavior in pwPD.

In summary, this systematic review considered pwPD experiences and preferences for PA, their perceived motivators and barriers to engagement, as well as pwPD views on support mechanisms and 
behavioral change interventions designed to sustain participation.

The JBI Database of Systematic Reviews and Implementation Reports, the Cochrane Library, PROSPERO, CINAHL and MEDLINE were searched to identify if a systematic review on this theme has previously been conducted or was in progress. None was found.

\section{Review objectives}

The purpose of this qualitative systematic review was to synthesize the best available evidence on pwPD's experiences of and preferences for PA, their perceived enablers and barriers to engagement, as well as pwPD views on support mechanism and behavior change interventions designed to sustain participation.

Specifically the objectives were to:

- Explore pwPD's experiences of and preference(s) for PA.

- Explore pwPD's perceptions of barriers and enablers to PA.

- Identify, from the perspective of pwPD, the impact of support mechanisms and behavior change interventions in maintaining participation in PA.

\section{Inclusion criteria \\ Participants}

The review considered studies that included pwPD with a confirmed diagnosis.

\section{Phenomena of interest}

The review considered studies that explored experiences, preferences, barriers and enablers to PA in pwPD, including the use of behavioral interventions and support strategies.

\section{Context}

The context was any community setting where pwPD live.

\section{Types of studies}

Studies considered for this review were those in which qualitative data had been obtained and analyzed on the proposed phenomena of interest. Studies of interest included methodologies and approaches such as qualitative design, phenomenology, grounded theory, ethnography, action research and the qualitative aspect of mixed methods. There was no age limit applied to the studies considered for inclusion.

\section{Methods}

This qualitative systematic review utilized metaaggregation to synthesize the best available evidence following the published a priori protocol $^{39}$ registered with PROSPERO (CRD42017084025).

\section{Search strategy}

A three-step search strategy was utilized to find published and unpublished studies. Firstly, an initial limited search of MEDLINE was undertaken using preliminary keywords. Analysis of the text words contained in the title and abstract, and index terms used to describe the article were utilized to identify keywords that were more relevant. Based on this, the search strategy was developed and refined through discussion with the research team and an information specialist (see Appendix III for search strategies).

Subsequently, the final search strategy was applied to the following databases: MEDLINE (via OVID), Embase (via OVID), CINAHL (via EBSCO), AMED (via EBSCO), Scopus and Web of Science. The latter two include both published and unpublished studies. For some databases such as Scopus and Web of Science, the search strategy had to be modified. Each electronic database was searched from the inception of the database to June 30, 2017 to provide the most comprehensive synthesis possible. Only studies published in English were considered for inclusion. The search for unpublished studies included: PQDT, Conference Paper Index, OpenGrey, MedNar and Google. The CRO database was not searched (a deviation from the published a priori protocol) as it could no longer be accessed.

Lastly, a hand search of the reference list of included studies was undertaken to determine if there were any other studies for inclusion.

\section{Study selection}

Records of references were collated with the use of EndNote VX8 (Clarivate Analytics, PA, USA) and duplicates removed prior to screening. Two reviewers scanned all titles and abstracts to exclude papers that clearly did not align with the inclusion criteria, for example, not Parkinson's disease or not 
relating to PA. Full text articles were obtained for papers that met the inclusion criteria or where there was uncertainty; these were then independently assessed against the inclusion criteria by two reviewers. Any disagreements were resolved via discussion, and where needed, a third reviewer was consulted. The eligible studies selected through this process were then imported into the Joanna Briggs Institute System for the Unified Management, Assessment and Review of Information (JBI SUMARI; Joanna Briggs Institute, Adelaide, Australia).

\section{Assessment of methodological quality}

Eligible studies were appraised for methodological quality using the JBI Critical Appraisal Checklist for Qualitative Research. ${ }^{40}$ The checklist consists of 10 criteria concerning the methodology, methods and findings of qualitative studies. Three members of the review team participated in this step, and each paper was appraised independently by two of them. Discrepancies that arose between the reviewers were resolved through discussion. No studies were excluded based on methodological quality.

\section{Data extraction}

Qualitative data were extracted using the JBI Qualitative Data Extraction Tool. ${ }^{40}$ The primary reviewer initially performed data extraction for each study independently, which was subsequently checked for accuracy by a second reviewer. Firstly, following repeated reading of the studies, the findings and their accompanying illustrations were extracted. A finding is defined by the JBI as "a verbatim extract of the authors' analytic interpretation accompanied by either a participant voice, or fieldwork observations or other data". ${ }^{40(\mathrm{p} .40)}$ Findings were extracted based on themes or sub themes, depending on whether they were accompanied by an illustrative quotation directly attributed to a pwPD, and whether they related to the objectives of the review. During data extraction, a decision was taken to exclude two studies ${ }^{41,42}$ from extraction and further analyses as the findings of these studies were unsupported by any illustrations of the participant voice. Therefore, only 19 studies were selected for the synthesis.

The data extracted included specific details about methodology, method, phenomena of interest, setting, geographical location, cultural context, participants, data analysis and the study author's conclusions and reviewer's notes.

\section{Data synthesis}

The qualitative research findings from the included studies were synthesized following the JBI metaaggregative approach. ${ }^{40}$ Firstly, the primary reviewer and secondary reviewer rated each extracted finding independently according to the three levels of credibility, (unequivocal, credible or unsupported): ${ }^{1}$

- Unequivocal - findings with illustrations beyond reasonable doubt and thus not open to challenge.

- Credible - findings with illustration that are plausible and inferred from the date, but open to challenge.

- Unsupported - findings not supported by the data. $^{1}$

Consensus was agreed via discussion and where there was more than one quotation for a finding, the highest level of credibility among the quotations was assigned. Findings considered unsupported (i.e. no participant quote provided) were eliminated from further analysis.

Subsequently, the findings deemed unequivocal or credible were grouped into categories by the primary reviewer based on similarity of meaning and then discussed with the secondary reviewer until agreement was reached. The categories were then examined by the primary reviewer, and those with commonality were aggregated into synthesized statements which represented conclusions based on the findings from the included studies and which could form the basis for recommendations for practice and policy. The synthesized findings were reviewed and refined by all reviewers to ensure consensus.

\section{Assessing certainty in the findings}

A ConQual score was generated for each synthesized finding to provide a level of confidence in the evidence. ${ }^{1}$ The level of confidence for each synthesized finding is scored as high, moderate, low or very low based on the dependability of the primary studies and the credibility of their research findings. ConQual scores are downgraded in consecutive order, from a starting point of high, on the basis of summing the scores applied to dependability and credibility ratings.

Dependability was derived from answers to the five criteria on the JBI Critical Appraisal Checklist for Qualitative Research. The dependability score was then applied to the research findings from that study whereby a level of high was given to those 
studies which met four or more of the criteria, medium to those that met two or more of the criteria, and low to those studies that only satisfied one or more of the criteria. Subsequently, the dependability of the synthesized finding was derived from the balance of the aggregated level of dependability scores across the included studies. Findings that had more than $50 \%$ of included studies rated either high or moderate were assigned a moderate level of dependability.

Credibility of each research finding was established by determining the congruency between the study author's interpretation and the illustration (participant voice), and could be either unequivocal or credible. ${ }^{1}$ The credibility of the synthesized finding was determined by the balance of unequivocal and credible findings: if the finding only included unequivocal findings it was graded as high, a mixture of unequivocal and credible as moderate, and inclusion of only credible as low. See Appendices I and II for details of dependability and credibility scoring.

\section{Results \\ Study inclusion}

The search produced a total of 3592 results, which reduced to 3118 after de-duplication. Screening identified 63 studies deemed relevant to the objectives of the systematic review, based on the assessment of the titles and abstracts. The full texts of these papers were retrieved for review, following which 42 papers were excluded, based on their not meeting the inclusion criteria. See Figure 1 for the search results via the PRISMA flow diagram. ${ }^{43}$ See Appendix IV for the excluded studies, with reasons for their exclusion. The remaining 21 papers were examined for methodological quality. No studies were excluded due to methodological quality. However, during data extraction, two studies ${ }^{41,42}$ were excluded from further data synthesis, as their findings were not supported by an illustrative quote. The exclusion of unsupported findings from the synthesis would enhance the credibility score of the findings. Characteristics of the 19 included studies are presented in Appendix V.

\section{Methodological quality}

The methodological assessment of the studies is presented in Table 1. Methodological quality varied among the 21 studies, ranging from high to low. Sixteen studies achieved appraisal scores of $70 \%$ or more, indicating that at least seven or more of the 10 assessment criteria were met. Three studies achieved appraisal scores of over $50 \%$ indicating that five or more assessment criteria were met and one study achieved an appraisal score of $30 \%$ indicating criteria were met for only three out of 10 assessment criteria. ${ }^{40}$ With the exception of three studies, ${ }^{44-46}$ none of the included studies identified the philosophical perspective underpinning the research design. However there was congruity between the research methodology and the research question or objectives, and appropriate methods such as interviews and/or focus groups were utilized to collect data for all studies with the exception of one, ${ }^{47}$ in which the research methodology was not well detailed. Six of the 21 studies ${ }^{41,42,44,45,48,49}$ identified the beliefs and/or values of the authors from a cultural or theoretical perspective in relation to the research, and a statement identifying the influence of the researcher on the research and vice-versa was addressed in six studies. ${ }^{5,41,44,45,48,50}$ However, all included studies were scrutinized and ethically approved by an appropriate body.

\section{Characteristics of included studies}

The 19 included studies provided data on the views of pwPD in relation to their experiences and preferences for PA, their perceived enablers and barriers to engagement, and views on support mechanisms to promote engagement and sustained participation in PA. Qualitative data from the included studies were analyzed using grounded theory, ${ }^{44-46,51}$ phenomenology, ${ }^{30,49}$ and the qualitative aspect of mixed methods design. ${ }^{47,52-55}$ Several of the included studies $^{5,50,56-59}$ did not state the specific qualitative method used. Sample sizes ranged from one to 53 participants with a mix of genders. Where stated, the Hoehn and Yahr stages of participants ranged from stages one to three (mild to moderate disease severity), with the exception of three studies ${ }^{48,55,57}$ that included participants up to stages four (able to walk but dependent for all activities of daily living [ADL]) and five, respectively (wheelchair dependent). ${ }^{60}$ The studies were carried out in United Kingdom $(n=5)$, United States of America $(n=4)$, New Zealand $(\mathrm{n}=1)$, Canada $(\mathrm{n}=3)$, Sweden $(\mathrm{n}=2)$, Australia $(n=2)$ and Jordan $(n=2)$. Nine of the included studies explored the experiences of pwPD who undertook a variety of physical activities including walking, ${ }^{48,50,52}$ dance, ${ }^{47,54,55,59}$ and exercise 


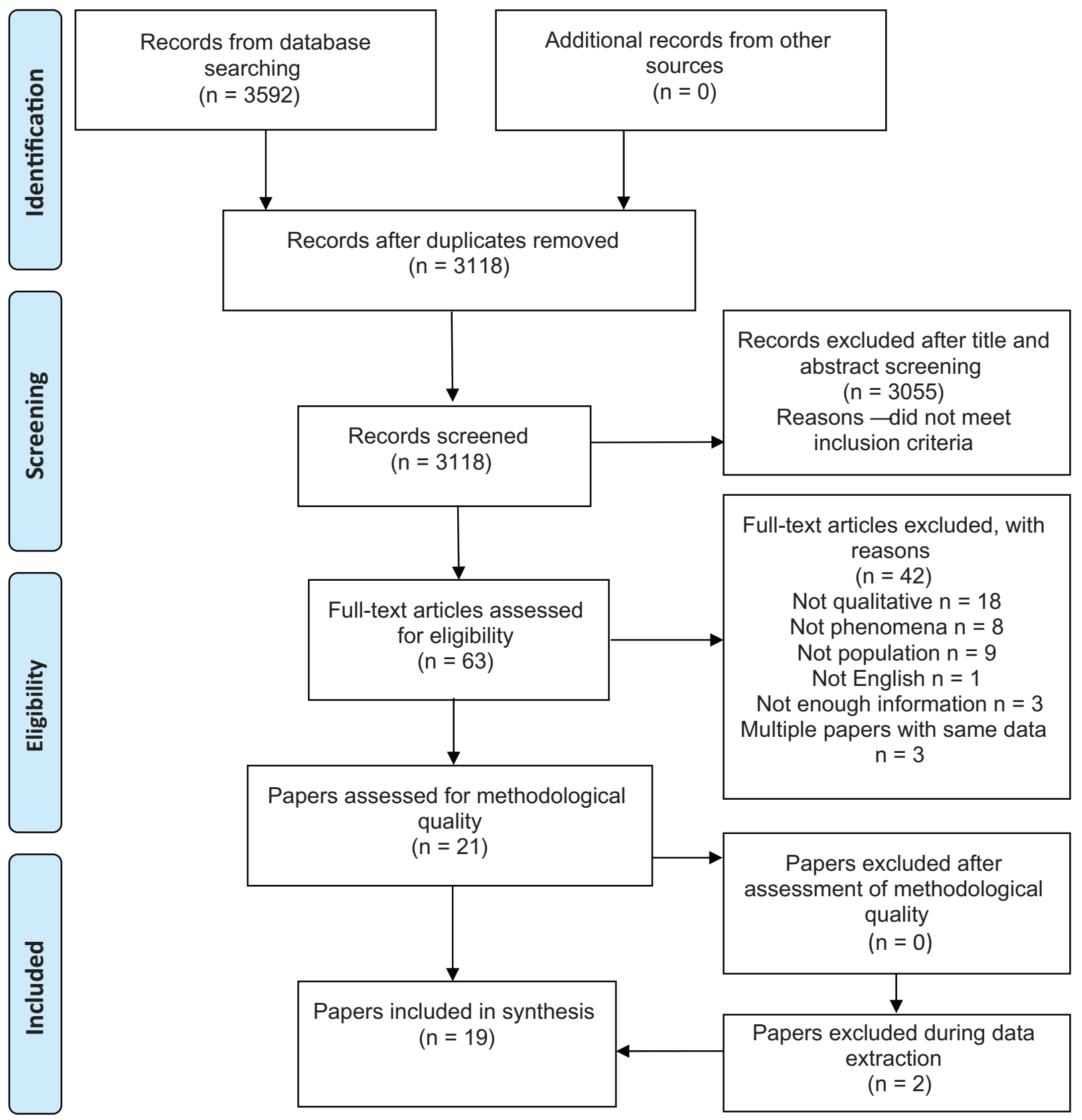

\section{Figure 1: Flowchart of study selection process ${ }^{43}$}

programs. ${ }^{44,46}$ One study explored the meaning of exercise and factors that influenced exercise behavior. ${ }^{45}$ One study explored the feasibility and cultural challenges of undertaking a home exercise program in Jordan. ${ }^{61}$ Six studies ${ }^{5,46,51,53,56,57}$ explored pwPD perceptions of motivators and barriers to PA. Only one study specifically explored how social support influenced PA participation. ${ }^{30}$ No studies explored the experiences or views of pwPD towards behavioral interventions designed to aid PA participation. Findings are presented as synthesized findings with a sample of illustrative quotes. See Appendix VI for a complete list of study findings, synthesized findings and illustrations. 
Table 1: Methodological quality of studies

\begin{tabular}{|c|c|c|c|c|c|c|c|c|c|c|c|}
\hline \multirow[b]{2}{*}{ Citation } & \multicolumn{11}{|c|}{ Question } \\
\hline & 1 & 2 & 3 & 4 & 5 & 6 & 7 & 8 & 9 & 10 & $/ 10$ \\
\hline Bassett et al. $(2012)^{52}$ & $\mathrm{~N}$ & $\mathrm{Y}$ & Y & $\mathrm{Y}$ & $\mathrm{Y}$ & $\mathrm{N}$ & $\mathrm{N}$ & $\mathrm{Y}$ & $\mathrm{Y}$ & $\mathrm{Y}$ & $7 / 10$ \\
\hline Bognar et al. $(2017)^{59}$ & $\mathrm{~N}$ & $Y$ & $\mathrm{Y}$ & $\mathrm{Y}$ & $\mathrm{Y}$ & $\mathrm{N}$ & $\mathrm{N}$ & $\mathrm{Y}$ & $\mathrm{Y}$ & $\mathrm{Y}$ & $7 / 10$ \\
\hline Crizzle et al. $(2012)^{5}$ & $\mathrm{~N}$ & Y & $\mathrm{Y}$ & $\mathrm{Y}$ & Y & $\mathrm{N}$ & $\mathrm{Y}$ & $\mathrm{Y}$ & $\mathrm{Y}$ & $\mathrm{Y}$ & $8 / 10$ \\
\hline Davis et al. $(2003)^{58}$ & $\mathrm{~N}$ & Y & Y & $\mathrm{Y}$ & $\mathrm{Y}$ & $\mathrm{N}$ & $\mathrm{N}$ & $\mathrm{Y}$ & $\mathrm{N}$ & $\mathrm{Y}$ & $6 / 10$ \\
\hline Elsworth et al. $(2009)^{42}$ & $\mathrm{~N}$ & Y & Y & Y & $\mathrm{Y}$ & $\mathrm{N}$ & $\mathrm{N}$ & Y & Y & $\mathrm{Y}$ & $7 / 10$ \\
\hline Erikson et al. $(2013)^{44}$ & $\mathrm{Y}$ & Y & $\mathrm{Y}$ & $\mathrm{Y}$ & $\mathrm{Y}$ & $\mathrm{Y}$ & $\mathrm{Y}$ & $\mathrm{Y}$ & $\mathrm{Y}$ & $\mathrm{Y}$ & $10 / 10$ \\
\hline Hammarlund et al. $(2014)^{48}$ & $\mathrm{~N}$ & $\mathrm{Y}$ & $\mathrm{Y}$ & $\mathrm{Y}$ & $\mathrm{Y}$ & $\mathrm{N}$ & $\mathrm{Y}$ & $\mathrm{Y}$ & $\mathrm{Y}$ & $\mathrm{Y}$ & $8 / 10$ \\
\hline Hislop et al. $(2015)^{53}$ & $\mathrm{~N}$ & $\mathrm{Y}$ & $\mathrm{Y}$ & $\mathrm{U}$ & $\mathrm{U}$ & $\mathrm{N}$ & $\mathrm{N}$ & $\mathrm{N}$ & $\mathrm{Y}$ & $\mathrm{U}$ & $3 / 10$ \\
\hline Houston et al. $(2015)^{47}$ & $\mathrm{~N}$ & $\mathrm{~N}$ & $\mathrm{Y}$ & $\mathrm{U}$ & $\mathrm{Y}$ & $\mathrm{N}$ & $\mathrm{N}$ & $\mathrm{Y}$ & $\mathrm{Y}$ & $\mathrm{Y}$ & $5 / 10$ \\
\hline Jones et al. $(2008)^{50}$ & $\mathrm{~N}$ & Y & $\mathrm{Y}$ & $\mathrm{Y}$ & $\mathrm{Y}$ & Y & $\mathrm{Y}$ & $\mathrm{Y}$ & $\mathrm{Y}$ & $\mathrm{Y}$ & $9 / 10$ \\
\hline Khalil et al. $(2017)^{61}$ & $\mathrm{~N}$ & $\mathrm{Y}$ & Y & Y & Y & $\mathrm{N}$ & $\mathrm{N}$ & $\mathrm{Y}$ & Y & Y & $7 / 10$ \\
\hline Khalil et al. (2016) & $\mathrm{N}$ & $\mathrm{Y}$ & Y & $\mathrm{Y}$ & $\mathrm{Y}$ & $\mathrm{N}$ & $\mathrm{N}$ & Y & $\mathrm{Y}$ & Y & $7 / 10$ \\
\hline Kunkel et al. $(2017)^{54}$ & $\mathrm{~N}$ & $\mathrm{Y}$ & Y & Y & $\mathrm{Y}$ & $\mathrm{Y}$ & $\mathrm{N}$ & $\mathrm{Y}$ & $\mathrm{Y}$ & $\mathrm{Y}$ & $8 / 10$ \\
\hline O’Brien et al. $(2016)^{45}$ & $\mathrm{Y}$ & $\mathrm{Y}$ & $\mathrm{Y}$ & $\mathrm{Y}$ & $\mathrm{Y}$ & $\mathrm{N}$ & $\mathrm{Y}$ & $\mathrm{Y}$ & $\mathrm{Y}$ & $\mathrm{Y}$ & $9 / 10$ \\
\hline O’Brien et al. $(2008)^{46}$ & $\mathrm{Y}$ & Y & $\mathrm{Y}$ & $\mathrm{Y}$ & $\mathrm{Y}$ & $Y$ & $\mathrm{~N}$ & $\mathrm{Y}$ & Y & $\mathrm{Y}$ & $9 / 10$ \\
\hline Pretzer-Aboff et al. (2009) & $\mathrm{N}$ & Y & $\mathrm{Y}$ & $\mathrm{Y}$ & $\mathrm{Y}$ & $\mathrm{N}$ & $\mathrm{N}$ & $\mathrm{Y}$ & $\mathrm{Y}$ & $\mathrm{Y}$ & $7 / 10$ \\
\hline Quinn et al. ${ }^{56}(2010)^{56}$ & $\mathrm{~N}$ & Y & $\mathrm{Y}$ & $\mathrm{Y}$ & $\mathrm{Y}$ & $\mathrm{N}$ & $\mathrm{N}$ & $\mathrm{Y}$ & $\mathrm{Y}$ & $\mathrm{Y}$ & $7 / 10$ \\
\hline Ramasamy $(2015)^{41}$ & $\mathrm{~N}$ & Y & $\mathrm{Y}$ & $\mathrm{U}$ & $\mathrm{Y}$ & Y & $\mathrm{Y}$ & $\mathrm{N}$ & $\mathrm{Y}$ & $\mathrm{U}$ & $6 / 10$ \\
\hline Ravenek et al. $(2009)^{30}$ & $\mathrm{~N}$ & $\mathrm{Y}$ & $\mathrm{Y}$ & $\mathrm{Y}$ & $\mathrm{Y}$ & $\mathrm{N}$ & $\mathrm{N}$ & $\mathrm{Y}$ & $\mathrm{Y}$ & $\mathrm{Y}$ & $7 / 10$ \\
\hline Sheehy $(2014)^{49}$ & $\mathrm{~N}$ & Y & $\mathrm{Y}$ & $\mathrm{Y}$ & Y & $\mathrm{Y}$ & $\mathrm{N}$ & $\mathrm{Y}$ & Y & $\mathrm{Y}$ & $8 / 10$ \\
\hline Westheimer et al. $(2015)^{55}$ & $\mathrm{~N}$ & $\mathrm{Y}$ & $\mathrm{Y}$ & $\mathrm{N}$ & $\mathrm{Y}$ & $\mathrm{N}$ & $\mathrm{N}$ & $\mathrm{N}$ & $\mathrm{Y}$ & $\mathrm{Y}$ & $5 / 10$ \\
\hline
\end{tabular}

$\mathrm{Y}$, yes; $\mathrm{N}$, no; $\mathrm{U}$, unclear.

Questions:

1. Is there congruity between the stated philosophical perspective and the research methodology?

2. Is there congruity between the research methodology and the research question or objectives?

3. Is there congruity between the research methodology and the methods used to collect data?

4. Is there congruity between the research methodology and the representation and analysis of the data?

5 . Is there congruity between the research methodology and the interpretation of the results?

6 . Is there a statement locating the researcher culturally or theoretically?

7. Is the influence of the researcher on the research, and vice-versa, addressed?

8 . Are participants, and their voices, adequately represented?

9. Is the research ethical, according to current criteria, or for recent studies, and is there evidence of ethical approval by an appropriate body?

10. Do the conclusions drawn in the research report flow from the analysis, or interpretation, of the data?

\section{Review findings}

Eight synthesized findings were identified: they consisted of 20 categories and 105 findings from 19 papers.

Findings are organized into synthesized findings representing the three objectives of the study.
Objective 1: Explore pwPD's experiences of and preference(s) for $P A$

\section{Synthesized finding 1}

Participating in PA is seen as positive; participants report improvements in physical and psychological function and symptom control. Participating in PA 
leads to holistic changes, including a sense of achievement, improved confidence and wellbeing.

This synthesized finding was derived from 13 findings and two categories:

Category 1.1: Activities improve symptoms, have a positive impact on wellbeing and quality of life, and increase confidence.

Physical activity was perceived to improve both physical and psychological symptoms of Parkinson's disease, with both aspects deemed important for wellbeing. Improved physical and/or psychological symptoms enhanced participants' view on their quality of life, and regular engagement in PA increased their ability to undertake functional tasks. Regular engagement enhanced confidence in their ability to partake in activities and opened up their world to new possibilities.

"I find it so much easier to reach for items in shelves that I had difficulty getting to before. I can also cut my meat and vegetables better. I feel like I can put more pressure on the knife. Such little things, but these play a big part of my daily living. I can't believe these things can be improved just by exercising." $59(\mathrm{p} 180)$

"[It] just gives you an all over good feeling that you can, you can do it and, uh, I would never have thought, before I had the Parkinson's, that I could do anything like this". ${ }^{49(\mathrm{p} 35)}$

"The [Nordic walking] poles opened up my world again. I am not so overwhelmed on social occasions. I used to hesitate going where I knew there was going to be a crowd-especially if there was a possibility that there would not be seats provided. Now I just take my poles and use them as supports and that helps. ...",52(p120)

Category 1.2: Regular achievement of physical activity programs.

People with Parkinson's disease expressed a sense of achievement from attending and participating in a regular PA programs. The achievement was bolstered by the emotional and social benefits of undertaking PA in a group setting.

".. I thinks it's very good with that hour that... at least once a week gets... the muscles there and there ... and do something.... I feel satisfaction by being able to participate... that is the primary thing, I think. And ... also to feel that the body manages, because... I sometimes think when we're exercising, that we are incredibly capable considering our capacity. And sometime you're not capable at all, but ... then when you experience that "Oh god, I can do this" then you get a kick." 44(p2242)

\section{Synthesized finding 2}

Parkinson's disease is perceived to impact on all aspects of $P A$, with temporal fluctuation in symptoms presenting both emotional and physical challenges. Changes to the level and type of PA and individual strategies are used to maximize participation.

This synthesized finding was derived from 20 findings grouped into two categories:

Category 2.1: The impact of Parkinson's disease is individual and unpredictable, and presents challenges with functional activities and a loss of identity as an active individual; these can be a source of tension.

People with Parkinson's disease identified difficulties with a wide range of PAs and tasks, and these difficulties varied depending on the individual and from day to day. Being unable to undertake a task could be a source of tension. Participants expressed a range of emotional reactions, including frustration and anger as well as sadness at the loss of activities that they were previously able to do. This often resulted in pwPD having to change their lifestyle, with some withdrawing from society.

Person with Parkinson's: She irritated me to the extent that I said "Look I'm supposed to be leading [here!]" and she said "Yes, but you're not doing it right!" [laughing] ${ }^{54(p 5)}$

“.... It's draining your energy and it saddens me. You become angry with yourself when it's hard and things don't work as you want them to. When you do something, things that you've done a hundred times before with ease, take forever to do today ${ }^{, 48(p 659)}$

Category 2.2: Coping strategies are individual to the person.

Participants described a number of different strategies (which often involved cognitive effort) that 
they employed in order to walk and participate in physical activities, including use of equipment, and planning and timing of medication, with avoidance of activities not deemed important. Maintaining a positive outlook was considered a key aspect of managing the disease as well as trying to maintain a sense of normalcy.

"If I know that I am doing something special then I have to adjust my medication accordingly. And you have to constantly think, think ahead, plan a little more of your activities in relation to the medication and so.... It has clearly changed my life, it really has..." 58(p659)

"I think when I go off and I remember to walk so tall, and keep my head up, and swing my arms, just to do movement, and if I think I go dancing and sit up straight, and shoulders back, head up, it's a great image to hold on to.",47(p22)

"Every once in a while I think, 'bey, I'm lucky I have Parkinson's', I have friends who have had lung problems, who have had heart attacks, total loss of vision and are buried. We are alive, $58(p 41)$

\section{Synthesized finding 3}

Participation in PA is highly individual, with participants valuing activities which are perceived as personally relevant and tailored to their needs and preferences. Participant perceptions of PA are affected by expectations and self-evaluation of progress.

This synthesized finding was derived from nine findings grouped into two categories:

Category 3.1: Participation in physical activity is affected by disease presentation and is highly individual.

People with Parkinson's highlighted that the highly individualized nature of the disease led to them undertaking PA that was specific to their unique circumstances. Participants noted that their participation in PA was influenced by their personality traits: resilience, need for independence, determination and sense of humor. Equally, while the nature of the disease was individualized, so were the coping strategies for that individual.
"With this disease you have similarities, you know they are just similar and at other times it's like your disease is custom made to you,. $58(p 40)$

Category 3.2: Participants report individual preferences for the settings for physical activity. Tailored goals and self-evaluation of progress are important considerations for their engagement.

The location was considered important for the participants, with some preferring the home and others a hospital or community setting. Whatever the setting, participants were eager that goals were tailored to their needs. Participants' expectations and self-evaluation of the PA program were often different from their instructor's viewpoint.

"The commitment to the program will be better if it is at the hospital and under the supervision of a therapist. At home, you may get busy with other stuff; defer the exercises and end-up not doing them." $57(p 514)$

"I tend to exercise at home rather than going to the gym because it fits in with my lifestyle really. At the weekend I have my granddanghter and also I am working three times a week." ${ }^{, 56(p 922)}$

'I believe that at my stage of Parkinson's progress that I have to be concerned about power and balance." $45(p 6)$

\section{Synthesized finding 4}

External factors can affect participants' experience of PA. Involvement of family members/friends and use of music make sessions enjoyable and increase wellbeing. Support from instructors to ensure PA programs are structured and simple to undertake, to explain the relevance of activities and to facilitate progression gives participants confidence and enhances their participation.

This finding was comprised of 11 findings and three categories:

Category 4.1: Reassurance and support from group members, instructor, partner or family are important for participation in PA, while the use of music enhances enjoyment.

People with Parkinson's disease felt that an important aspect of group PA programs was the 
humor and optimism from all members of the group, and that a qualified instructor knowledgeable about the disease was a source of support and reassurance. Music as part of the program helped with movement and enjoyment.

"The dance made me feel more graceful, moving and flowing with the music, it made me feel that I had to move when the music started.",47(p19)

'I wouldn't have liked, I wouldn't have gone if [husband] hadn't have been my partner I don't think. I liked that very much, I liked it a lot." ${ }^{, 54(p 3)}$

"A few people started off better than me... and that bothered me. But the instructor told me not to worry about it and that I should work at my own pace. I didn't think I could do it. I nearly gave up. But the leader always insisted that I could do it, so I had to prove myself and then I could." $5(p 180)$

Category 4.2: Supervision from an instructor who can provide education on the benefits of exercise as well as prescribe and progress exercises enhances participation.

Participants felt that an important influence on their participation was supervision while undertaking the exercise program as well as the education given by the instructor on the relevance and usefulness of the exercises. Furthermore, it was important that the exercise program was both challenging and progressive.

"For the first time ever I felt that someone was truly taking care of me that was the best piece of the intervention. It made me feel in turn that I should take care of myself by committing to the exercise program. The therapist was an excellent motivator." ${ }^{61(p 25)}$

"I think it should be clear how the exercises fit into the program. That's helpful. If I feel that the exercises make a difference, then I can do them more. Also having the general idea of the benefits of doing the exercise. I think the exercise is good for me and by doing the exercise I appreciate that there is a difference." 56 (p923)
Category 4.3: Simplicity of exercise programs.

Participants felt that having a simple exercise program enhanced participation both in class and also when they were undertaking exercises at home. A perceived lack of clarity or relevance of the exercise program was considered to inhibit participation.

"The DVD was simple and easy to follow its use at home was a strong motivator to continue doing the exercises." $" 61(p 25)$

"Sessions with physiotherapy actually taking me through with the exercises; that is good I think. They gave me exercises to do at home but I have not continued using them because of a couple of things actually. For back exercises there was no standard to do them. So, you do a lot and a lot of exercises like the hand behind the shoulder or the hand in front but actually you do not know what for the exercises are and the differences are tricky.... I think exercises should be simple and clear how they fit into the program. That's belpful." ${ }^{56(p 923)}$

Table 2 provides a summary of the results of the meta-synthesis of the research findings under Objective 1.

\section{Objective 2: Explore pwPD's perceptions of} barriers and enablers to $P A$

\section{Synthesized finding $\mathbf{5}$}

A personal desire to maintain independence and a belief that PA can slow deterioration are driving forces for participation. Motivation is enhanced by perceived improvement in symptoms and feelings of accountability to oneself or others.

This synthesized finding was derived from 12 findings and three categories.

Category 5.1: Perceived improvement in wellbeing and physical ability aids motivation to participate in PA.

Participants identified that if they perceived an improvement in their performance, whether this was physical or psychological, this aided their desire to continue to participate in the PA program.

"The exercise program has affected me both mentally and physically before I got to know you and was introduced to this program I used to lock myself away at home. Fear of falling was 
Table 2: Findings, illustrations, categories and synthesized finding (Objective 1: explore the experiences of and preferences for physical activity for people with Parkinson's disease)

\begin{tabular}{|c|c|c|c|c|}
\hline Author (date) & Findings & Illustration & Categories & Synthesized findings \\
\hline $\begin{array}{l}\text { Bassett et al. } \\
(2012)\end{array}$ & $\begin{array}{l}\text { Physical and psychological wellbe- } \\
\text { ing: When using the poles, the } \\
\text { participant found she could over- } \\
\text { come some of her physical and } \\
\text { psychological limitations [U] }\end{array}$ & $\begin{array}{l}\text { "The poles opened up my world } \\
\text { again. I am not so overwhelmed on } \\
\text { social occasions. I used to hesitate } \\
\text { going where I knew there was going } \\
\text { to be a crowd - especially if there } \\
\text { was a possibility that there would } \\
\text { not be seats provided. Now I just } \\
\text { take my poles and use them as } \\
\text { supports and that helps...". Partici- } \\
\text { pant pg } 120[\mathrm{U}]\end{array}$ & \multirow[t]{9}{*}{$\begin{array}{l}\text { 1.1 Activities improve symptoms, have a } \\
\text { positive impact on wellbeing and quality } \\
\text { of life, and increase confidence. }\end{array}$} & \multirow[t]{9}{*}{$\begin{array}{l}\text { 1. Participating in PA is seen as } \\
\text { positive; participants report } \\
\text { improvements in physical and psy } \\
\text { chological function and symptom } \\
\text { control. Participating in PA leads } \\
\text { to holistic changes, including a } \\
\text { sense of achievement, improved } \\
\text { confidence and wellbeing. }\end{array}$} \\
\hline $\begin{array}{l}\text { Bassett et al. } \\
(2012)\end{array}$ & $\begin{array}{l}\text { General health: Participant noted } \\
\text { that over the Nordic walking } \\
\text { phase, changes occurred in her } \\
\text { general wellbeing especially with } \\
\text { her appetite, sleep and energy } \\
\text { levels. [U] }\end{array}$ & $\begin{array}{l}\text { "After a couple of weeks of Nordic } \\
\text { walking I actually felt hungry } \\
\text { again!... I hadn't realized that I had } \\
\text { not felt that for a while. I had been } \\
\text { worried about having to use seda- } \\
\text { tives to sleep. A few weeks into the } \\
\text { programme... I cut my dose and } \\
\text { found I was able to get back to } \\
\text { sleep after waking in the night." } \\
\text { p120 [U] }\end{array}$ & & \\
\hline $\begin{array}{l}\text { Bognar et al. } \\
(2016)\end{array}$ & $\begin{array}{l}\text { Dance and the mind: Participants } \\
\text { reported that the class provided } \\
\text { opportunities to coordinate their } \\
\text { body in new ways and promoted } \\
\text { use of different areas of the brain. } \\
{[\mathrm{U}]}\end{array}$ & $\begin{array}{l}\text { "[The brain] gets exercise at Danc- } \\
\text { ing with Parkinson's because most } \\
\text { dances are more than one step... } \\
\text { when they give me the second thing } \\
\text { to do at the same time... I notice it } \\
\text { immediately." [P9] pg4 [U] }\end{array}$ & & \\
\hline $\begin{array}{l}\text { Bognar et al. } \\
(2016)\end{array}$ & $\begin{array}{l}\text { The emotional experience: partici- } \\
\text { pants agreed that attending the } \\
\text { dance class improved their mood. } \\
{[\mathrm{U}]}\end{array}$ & $\begin{array}{l}\text { “.... you grab a partner and go } \\
\text { around, and she smiles, but can't } \\
\text { speak and she's happy. Emotionally } \\
\text { it affects me as well because it's my } \\
\text { benefit to make her happy" [P8] } \\
\text { pg4 [U] }\end{array}$ & & \\
\hline $\begin{array}{l}\text { Crizzle et al. } \\
(2012)\end{array}$ & $\begin{array}{l}\text { Improved psychological well-being } \\
\text { from perceived physical benefits: } \\
\text { Participants noted improvement in } \\
\text { their normal everyday activities. } \\
{[\mathrm{U}]}\end{array}$ & $\begin{array}{l}\text { Participant } 1 \text { "I find it so much } \\
\text { easier to reach for items in shelves } \\
\text { that I had difficulty getting to } \\
\text { before. I can also cut my meat and } \\
\text { vegetables better. I feel like I can } \\
\text { put more pressure on the knife. Such } \\
\text { little things, but these play a big } \\
\text { part of my daily living. I can't' } \\
\text { believe these things can be improved } \\
\text { just by exercising". P1 pg } 180 \text { [U] }\end{array}$ & & \\
\hline $\begin{array}{l}\text { Hammarlund } \\
\text { et al. (2014) }\end{array}$ & $\begin{array}{l}\text { Independence and Integrity: Partici- } \\
\text { pants felt that the ability to walk } \\
\text { was important in managing their } \\
\text { daily activities and work and was } \\
\text { central to participation in life like } \\
\text { everyone else. [U] }\end{array}$ & $\begin{array}{l}\text { "Being mobile, to be able to partici- } \\
\text { pate in life normally, to be able to } \\
\text { move around, take the train, drive } \\
\text { the car... to be able to walk to } \\
\text { different things without any trou- } \\
\text { ble." Participant pg } 660 \text { [U] }\end{array}$ & & \\
\hline $\begin{array}{l}\text { Houston } \\
\text { et al. (2015) }\end{array}$ & $\begin{array}{l}\text { Balance and stability: Participants } \\
\text { have mentioned an improved sense } \\
\text { of body awareness both inside and } \\
\text { outside of the dance studio with } \\
\text { participants also noting a lack of } \\
\text { freezing. [U] }\end{array}$ & $\begin{array}{l}\text { "I get a bit of freezing in movement, } \\
\text { but I feel I'm less freezing when I } \\
\text { come to class. I don't freeze here } \\
\text { and when I go back home I don't } \\
\text { freeze as often that day." P pg } 22 \\
\text { [U] }\end{array}$ & & \\
\hline $\begin{array}{l}\text { Houston } \\
\text { et al. (2015) }\end{array}$ & $\begin{array}{l}\text { Progression of Parkinson's: Partici- } \\
\text { pants noted that the physical } \\
\text { changes may not be as obvious or } \\
\text { distinctive as the mental benefits. } \\
{[\mathrm{U}]}\end{array}$ & $\begin{array}{l}\text { "It's not just I'm in the mood, but } \\
\text { physically I feel different. I don't } \\
\text { think about it all the time, but } \\
\text { suddenly I realise how much better I } \\
\text { feel. More movement, more energy, } \\
\text { certainly more energised... I want } \\
\text { to stay positive and not think about } \\
\text { Parkinson's." Participant pg } 24 \text { [U] }\end{array}$ & & \\
\hline $\begin{array}{l}\text { O'Brien et al. } \\
\text { (2008) }\end{array}$ & $\begin{array}{l}\text { The outcomes were broader than } \\
\text { just physical outcomes: participants } \\
\text { said that there were no significant } \\
\text { physical gains, yet they commented } \\
\text { favourably about their experiences. } \\
\text { [U] }\end{array}$ & $\begin{array}{l}\text { Participant } 8 \text { said: "I haven't } \\
\text { noticed anything physically; maybe } \\
\text { just a marginal improvement in the } \\
\text { strength of my arms. With regard to } \\
\text { my legs, I don't think there has been } \\
\text { much change at all, but mentally I } \\
\text { think, oh I don't know, I think just } \\
\text { being involved with other people } \\
\text { sort of, even at this level, helps me a } \\
\text { bit." Pg } 1354 \text { [U] }\end{array}$ & & \\
\hline
\end{tabular}


Table 2: (Continued)

\begin{tabular}{|c|c|c|c|c|}
\hline Author (date) & Findings & Illustration & Categories & Synthesized findings \\
\hline $\begin{array}{l}\text { Sheehey } \\
\text { (2014) }\end{array}$ & $\begin{array}{l}\text { Psychological outcomes: being in } \\
\text { the programme and improving } \\
\text { physical competence allowed parti- } \\
\text { cipants to express surprise at their } \\
\text { ability and a new-found confidence } \\
\text { and realization that they have new } \\
\text { possibilities. [U] }\end{array}$ & $\begin{array}{l}\text { "It just gives you an all-over good } \\
\text { feeling that you can, you can do it } \\
\text { and, uh, I would never have } \\
\text { thought, before I had the Parkin- } \\
\text { son's, that I could do anything like } \\
\text { this." (Silvia) pg } 35 \text { [U] }\end{array}$ & & \\
\hline $\begin{array}{l}\text { Westheimer } \\
\text { et al. (2015) }\end{array}$ & $\begin{array}{l}\text { The participants reported benefits } \\
\text { related to QOL and wellbeing that } \\
\text { were not reflected in changes on } \\
\text { quantitative measures. [C] }\end{array}$ & $\begin{array}{l}\text { Less helpless; "doing something to } \\
\text { help myself" Table } 5 \text { pg1628 [C] }\end{array}$ & & \\
\hline $\begin{array}{l}\text { Erikson et al. } \\
\text { (2013) }\end{array}$ & $\begin{array}{l}\text { Having feelings of coherence: The } \\
\text { achievement of attending an exer- } \\
\text { cise program and having support } \\
\text { by the regularity and the promot- } \\
\text { ing of the programme were impor- } \\
\text { tant facilitating factors for those } \\
\text { participants. [U] }\end{array}$ & $\begin{array}{l}\text { “... I thinks it's very good with that } \\
\text { hour that... at least once a week } \\
\text { gets... the muscles there and there } \\
\ldots \text { and do something. ... I feel } \\
\text { satisfaction by being able to } \\
\text { participate... that is the primary } \\
\text { thing, I think. And ... also to feel } \\
\text { that the body manages, because... I } \\
\text { somethings think when we're } \\
\text { exercising, that we are incredibly } \\
\text { capable considering our capacity. } \\
\text { And sometimes you're not capable } \\
\text { at all, but ... then when you experi- } \\
\text { ence that "Oh god, I can do this" } \\
\text { then you get a kick..." participant } \\
\text { pg } 2242[\mathrm{U}]\end{array}$ & $\begin{array}{l}1.2 \text { Regular achievement of physical } \\
\text { activity programs. }\end{array}$ & \\
\hline $\begin{array}{l}\text { Erikson et al. } \\
\text { (2013) }\end{array}$ & $\begin{array}{l}\text { Experience well-being through } \\
\text { accomplishing: focused on an } \\
\text { aspect of well-being that derived } \\
\text { from the satisfaction of the } \\
\text { achievements in itself [U] }\end{array}$ & $\begin{array}{l}\text { “... the body feels good, he say } \\
\text { "oh, it's so good that you've done } \\
\text { this" and so on and ... it's difficult } \\
\text { to say what it is but... I think I feel } \\
\text { very good when I've achieved some- } \\
\text { thing." Participant pg } 2242[\mathrm{U}]\end{array}$ & & \\
\hline $\begin{array}{l}\text { Davis et al. } \\
\text { (2003) }\end{array}$ & $\begin{array}{l}\text { Functional mobility: Participants } \\
\text { identified additional areas that } \\
\text { were problematic; decreased mobil- } \\
\text { ity in bed; transfers from sit to } \\
\text { stand as well as solutions. [U] }\end{array}$ & $\begin{array}{l}\text { "Moving around in bed is almost an } \\
\text { impossibility. There seems to be so } \\
\text { much resistance between the sheets } \\
\text { and it just seems impossible" partic- } \\
\text { ipant pg40 [U] }\end{array}$ & \multirow[t]{6}{*}{$\begin{array}{l}2.1 \text { The impact of PD is individual and } \\
\text { unpredictable, and presents challenges } \\
\text { with functional activities and a loss of } \\
\text { identity as an active individual; these can } \\
\text { be a source of tension. }\end{array}$} & \multirow{6}{*}{$\begin{array}{l}\text { 2. PD is perceived to impact on all } \\
\text { aspects of PA, with temporal fluc- } \\
\text { tuation in symptoms presenting } \\
\text { both emotional and physical chal- } \\
\text { lenges. Changes to the level and } \\
\text { type of PA and individual strategies } \\
\text { are used to maximize participation. }\end{array}$} \\
\hline $\begin{array}{l}\text { Davis et al. } \\
\text { (2003) }\end{array}$ & $\begin{array}{l}\text { Walking: Participants identified } 4 \\
\text { specific symptoms that affected } \\
\text { their ability to walk; difficulty initi- } \\
\text { ating movement, shuffling, festinat- } \\
\text { ing gait and freezing. [U] }\end{array}$ & $\begin{array}{l}\text { "It affects the first step I take, the } \\
\text { second and third steps are a lot } \\
\text { easier than the first step. So, if get } \\
\text { pointed in the right direction, and I } \\
\text { get moving, I can continue moving } \\
\text { but that first step can be a real } \\
\text { challenge sometimes." pg40 [U] }\end{array}$ & & \\
\hline $\begin{array}{l}\text { Davis et al. } \\
\text { (2003) }\end{array}$ & $\begin{array}{l}\text { Falls: Issues pertaining to falls } \\
\text { included their unique experience of } \\
\text { falling, how falls have impacted } \\
\text { their life and measure they have } \\
\text { taken to prevent future falls. [U] }\end{array}$ & $\begin{array}{l}\text { "I think balance is probably for me } \\
\text { the worst thing... I've had one fall, } \\
\text { but I'll remember that 'til they bury } \\
\text { me, that sudden realisation of what } \\
\text { happened. Fortunately, I was in my } \\
\text { bedroom and fell on the nice car- } \\
\text { peted floor, but it was a hell of a } \\
\text { sensation." participant pg } 40 \text { [U] }\end{array}$ & & \\
\hline $\begin{array}{l}\text { Davis et al. } \\
(2003)\end{array}$ & $\begin{array}{l}\text { Medication cycles were recognised } \\
\text { as a leading contributor to partici- } \\
\text { pants' physical limitations. [U] }\end{array}$ & $\begin{array}{l}\text { "I noticed my problems walking are } \\
\text { dependent on my medication... I } \\
\text { skip my medication, my balance gets } \\
\text { bad, I lose my stride, and I feel } \\
\text { uncomfortable walking." pg41 [U] }\end{array}$ & & \\
\hline $\begin{array}{l}\text { Hammarlund } \\
\text { et al. (2014) }\end{array}$ & $\begin{array}{l}\text { Emotional reactions: Walking diffi- } \\
\text { culties were perceived as aggravat- } \\
\text { ing and problematic, causing } \\
\text { feelings of sadness and hopeless- } \\
\text { ness. Struggling with activities } \\
\text { resulted in frustration and anger. } \\
{[\mathrm{U}]}\end{array}$ & $\begin{array}{l}\text { “.... It's draining your energy and it } \\
\text { saddens me. You become angry with } \\
\text { yourself when it's hard and things } \\
\text { don't work as you want them to. } \\
\text { When you do something, things that } \\
\text { you've done a hundred times before } \\
\text { with ease, take forever to do today." } \\
\text { participant pg } 659 \text { [U] }\end{array}$ & & \\
\hline $\begin{array}{l}\text { Hammarlund } \\
\text { et al. (2014) }\end{array}$ & $\begin{array}{l}\text { Social consequences: Walking diffi- } \\
\text { culties had an impact on the ability } \\
\text { to participate in social activities } \\
\text { within or outside the family. [U] }\end{array}$ & $\begin{array}{l}\text { “... it changes the whole lifestyle. } \\
\text { You don't want to be amongst } \\
\text { others. You back away from being } \\
\text { in a crowd ... and at various events } \\
\text { one feels like an outsider. I simply } \\
\text { can't keep up anymore, not like I } \\
\text { used to.” participant pg } 660 \text { [U] }\end{array}$ & & \\
\hline
\end{tabular}


Table 2: (Continued)

\begin{tabular}{|c|c|c|c|c|}
\hline Author (date) & Findings & Illustration & Categories & Synthesized findings \\
\hline $\begin{array}{l}\text { Hammarlund } \\
\text { et al. (2014) }\end{array}$ & $\begin{array}{l}\text { Changed walking ability: participants } \\
\text { described gait had become slower, } \\
\text { they were dragging their feet or steps } \\
\text { could be tripping and the feet could } \\
\text { get stuck to the ground. [U] }\end{array}$ & $\begin{array}{l}\text { "So .... I felt like I sort of walked } \\
\text { and dragged a little on ... a little } \\
\text { like an old man, sort of dragged my } \\
\text { feet." participant pg } 659[\mathrm{U}]\end{array}$ & & \\
\hline $\begin{array}{l}\text { Jones et al. } \\
(2008)\end{array}$ & $\begin{array}{l}\text { Walking "after" - walking follow- } \\
\text { ing another activity: Participants } \\
\text { noted an increased difficulty in } \\
\text { walking after an activity. [C] }\end{array}$ & $\begin{array}{l}\text { "Increasingly manoeuvring out of din- } \\
\text { ing chairs at a table; rolling to the edge } \\
\text { of the bed in order to get the legs over } \\
\text { the edge; exiting the bath; turning after } \\
\text { standing were reported as challenging, } \\
\text { especially in the 'off' state. Initial } \\
\text { walking after all these activities was } \\
\text { likely to be characterised by shuffling } \\
\text { steps, potentially stooped posture, } \\
\text { often accompanied by unsteadiness..." } \\
\text { (author pg 11) [C] }\end{array}$ & & \\
\hline $\begin{array}{l}\text { Jones et al. } \\
(2008)\end{array}$ & $\begin{array}{l}\text { Walking "in" - walking in differ- } \\
\text { ent environments: outdoors posed } \\
\text { unpredictable challenges and were } \\
\text { disliked. Indoors doorways and fur- } \\
\text { niture, the need to constantly } \\
\text { change direction and to change } \\
\text { positions caused the main chal- } \\
\text { lenges. [U] }\end{array}$ & $\begin{array}{l}\text { "Having to stop, start and change } \\
\text { direction; being jostled; coping with } \\
\text { distractions; feeling pressured and } \\
\text { self-conscious; and having to con- } \\
\text { centrate on yourself and others, } \\
\text { were all tiring and often frighten- } \\
\text { ing." (author pg 10) [U] }\end{array}$ & & \\
\hline $\begin{array}{l}\text { Jones et al. } \\
(2008)\end{array}$ & $\begin{array}{l}\text { Walking whilst- walking while } \\
\text { doing something else: participants } \\
\text { noted that undertaking dual tasks } \\
\text { could become challenging. [U] }\end{array}$ & $\begin{array}{l}\text { "Sometimes if I concentrate too } \\
\text { much on not spilling the tea I sort } \\
\text { of forget about going up the stairs } \\
\ldots \text { It's as if my nervous system is } \\
\text { overloaded. Can't unscramble the } \\
\text { two messages" (P17 pg 9) [U] }\end{array}$ & & \\
\hline $\begin{array}{l}\text { Kunkel et al. } \\
\text { (2017) }\end{array}$ & $\begin{array}{l}\text { Managing potential sources of ten- } \\
\text { sion or difficulty: It was potentially } \\
\text { problematic, both for novice and } \\
\text { experienced dancing couples, when } \\
\text { a male dancer with Parkinson's } \\
\text { found it difficult to fulfil the tradi- } \\
\text { tional role that was expected of } \\
\text { him. [U] }\end{array}$ & $\begin{array}{l}\text { Person with Parkinson's: She irritated } \\
\text { me to the extent that I said, "Look } \\
\text { I'm supposed to be leading here!" } \\
\text { and she said "Yes, but you're not } \\
\text { doing it right!" [laughing] Andrew } \\
\text { age } 73 \text { H\&Y3 block 1) pg } 5 \text { [U] }\end{array}$ & & \\
\hline $\begin{array}{l}\text { O'Brien et al. } \\
\text { (2013) }\end{array}$ & $\begin{array}{l}\text { Loss of ability and loss of identity } \\
\text { as active self: Participants identified } \\
\text { a variety of physical and mental } \\
\text { changes attributable to both PD } \\
\text { and ageing that caused reduced } \\
\text { ability to engage in physical activi- } \\
\text { ties and consequently led to adap- } \\
\text { tations in the way they participated } \\
\text { in them. [U] }\end{array}$ & $\begin{array}{l}\text { "It's just the limitations of not being } \\
\text { able to do things you used to be } \\
\text { able to do. You move into a stage } \\
\text { where you can't do things that you } \\
\text { used to be able to do and I miss } \\
\text { very much not having a license to } \\
\text { drive a car and so I'm sort of } \\
\text { housebound except for my wife, my } \\
\text { wife drives me places but it's hard } \\
\text { on her too, so it's a hard time." P7 } \\
\text { pg } 3[\mathrm{U}]\end{array}$ & & \\
\hline $\begin{array}{l}\text { Pretzer Aboff } \\
\text { et al. }(2009)\end{array}$ & $\begin{array}{l}\text { Communication Difficulties: Diffi- } \\
\text { culty writing and speaking because } \\
\text { of tremor, hypophonia, and freeze } \\
\text { episodes were described as hamper- } \\
\text { ing the ability to communicate with } \\
\text { others. [U] }\end{array}$ & $\begin{array}{l}\text { "I cannot write. There is a stack of } \\
\text { condolence letters here, from when } \\
\text { my wife died. I initially said I will } \\
\text { answer each of them myself. I had } \\
\text { all the intentions of doing so, but I } \\
\text { couldn't write. So, I decided that I } \\
\text { could do it all with a machine, on } \\
\text { the computer. But I couldn't do it } \\
\text { on the computer because I couldn't } \\
\text { type either. Now I can't hit the right } \\
\text { key for nothing." No pg no. [U] }\end{array}$ & & \\
\hline $\begin{array}{l}\text { Davis et al. } \\
\text { (2003) }\end{array}$ & $\begin{array}{l}\text { Altering performance of activity of } \\
\text { daily living: participants managed } \\
\text { ADLs by altering how they were } \\
\text { achieved including; increased time } \\
\text { and being organised [C] }\end{array}$ & $\begin{array}{l}\text { "Some participants acknowledged } \\
\text { organising and taking advantage of } \\
\text { the productive time when their med- } \\
\text { ication was 'on'. Example of prepa- } \\
\text { ration were writing out checks } \\
\text { before going to the store and orga- } \\
\text { nising commonly used areas into } \\
\text { workstations that were equipped } \\
\text { with frequently needed items." } \\
\text { (author page 41) [C] }\end{array}$ & $\begin{array}{l}2.2 \text { Coping strategies are individual to } \\
\text { the person. }\end{array}$ & \\
\hline $\begin{array}{l}\text { Davis et al. } \\
\text { (2003) }\end{array}$ & $\begin{array}{l}\text { Participants coped with the disease } \\
\text { by attempting to maintain a sense } \\
\text { of normalcy. [C] }\end{array}$ & $\begin{array}{l}\text { "One participant explained how she } \\
\text { hid her foot, which showed dyskine- } \\
\text { sia, under the desk, to prevent co-- } \\
\text { workers from discovering that she } \\
\text { had PD." (author pg 41) [C] }\end{array}$ & & \\
\hline
\end{tabular}


Table 2: (Continued)

\begin{tabular}{|c|c|c|c|c|}
\hline Author (date) & Findings & Illustration & Categories & Synthesized findings \\
\hline $\begin{array}{l}\text { Davis et al. } \\
\text { (2003) }\end{array}$ & $\begin{array}{l}\text { Participants identified coping with } \\
\text { the disease through maintaining a } \\
\text { positive outlook. }[\mathrm{U}]\end{array}$ & $\begin{array}{l}\text { 'Every once in a while, I think, } \\
\text { 'hey, I'm lucky I have Parkinson's', I } \\
\text { have friends who have had lung } \\
\text { problems, who have had heart } \\
\text { attacks, total loss of vision and are } \\
\text { buried. We are alive" P pg41 [U] }\end{array}$ & & \\
\hline $\begin{array}{l}\text { Hammarlund } \\
\text { et al. (2014) }\end{array}$ & $\begin{array}{l}\text { Strategies to manage the impact of } \\
\text { walking difficulties: They chose to } \\
\text { accept the new situation, to plan } \\
\text { their lives in both the long and } \\
\text { short term, using cognitive strate- } \\
\text { gies to overcome difficulties. [U] }\end{array}$ & $\begin{array}{l}\text { "if I know that I am doing something } \\
\text { special then I have to adjust my } \\
\text { medication accordingly. And you } \\
\text { have to constantly think, think ahead, } \\
\text { plan a little more of your activities in } \\
\text { relation to the medication and so.... } \\
\text { It has clearly changed my life, it } \\
\text { really has..." participant pg } 659 \text { [U] }\end{array}$ & & \\
\hline $\begin{array}{l}\text { Houston } \\
\text { et al. (2015) }\end{array}$ & $\begin{array}{l}\text { Posture: Participants note the chal- } \\
\text { lenge in maintaining posture in } \\
\text { relation to dance and the difficul- } \\
\text { ties in maintaining posture outside } \\
\text { of the class in order to cause } \\
\text { permanent change [U] }\end{array}$ & $\begin{array}{l}\text { "I think when I go off and I remember } \\
\text { to walk so tall, and keep my head up, } \\
\text { and swing my arms, just to do move- } \\
\text { ment, and if I think I go dancing and } \\
\text { sit up straight, and shoulders back, } \\
\text { head up, it's a great image to hold on } \\
\text { to." Participant pg } 22 \text { [U] }\end{array}$ & & \\
\hline $\begin{array}{l}\text { Jones et al. } \\
\text { (2008) }\end{array}$ & $\begin{array}{l}\text { Monitoring: walking using concen- } \\
\text { tration: Participants needed to } \\
\text { monitor walking quality and con- } \\
\text { sciously correct deficits. [U] }\end{array}$ & $\begin{array}{l}\text { "... but I'm always watching, } \\
\text { thinking, terrified of falling over but } \\
\text { there's that feeling always that you } \\
\text { must watch where you are going." } \\
(05) . \text { Pg12 [U] }\end{array}$ & & \\
\hline $\begin{array}{l}\text { Jones et al. } \\
\text { (2008) }\end{array}$ & $\begin{array}{l}\text { Correcting: Walking through gener- } \\
\text { ating rhythm and size of steps. } \\
\text { Imagined or actual visual input was } \\
\text { used to start and maintain stepping } \\
\text { and overcoming freezing. [U] }\end{array}$ & $\begin{array}{l}\text { "I had to rehearse mentally if I was } \\
\text { going to take a step and then take } \\
\text { the step." (20). Pg } 13[\mathrm{U}]\end{array}$ & & \\
\hline $\begin{array}{l}\text { Davis et al. } \\
(2003)\end{array}$ & $\begin{array}{l}\text { Physical limitations and compensa- } \\
\text { tory strategies: participants shared } \\
\text { similar physical limitation related } \\
\text { to PD, however, the way in which } \\
\text { these limitations affected each par- } \\
\text { ticipant was unique. [U] }\end{array}$ & $\begin{array}{l}\text { "With this disease you have similari- } \\
\text { ties, you know they are just similar } \\
\text { and at other times it's like your } \\
\text { disease is custom made to you." } \\
\text { Participant pg } 40[\mathrm{U}]\end{array}$ & $\begin{array}{l}\text { 3.1 Participation in physical activity is } \\
\text { affected by disease presentation and is } \\
\text { highly individual. }\end{array}$ & $\begin{array}{l}\text { 3. Participation in PA is highly } \\
\text { individual, with participants valu- } \\
\text { ing activities which are perceived } \\
\text { as personally relevant and tailored } \\
\text { to their needs and preferences. } \\
\text { Participant perceptions of PA are }\end{array}$ \\
\hline $\begin{array}{l}\text { Erikson et al. } \\
\text { (2013) }\end{array}$ & $\begin{array}{l}\text { Trusting own experiences: meant } \\
\text { being attentive to the signals from } \\
\text { one's body and acting in the best } \\
\text { way according to one's knowledge, } \\
\text { beliefs and experiences. [C] }\end{array}$ & $\begin{array}{l}\text { “... I keep myself a bit busy at } \\
\text { home... I have recorded a lot of } \\
\text { tunes ... and do certain exercise } \\
\text { there... and so on. So ... I rarely sit } \\
\text { still... if I put it that way.” Partici- } \\
\text { pant pg } 2240[C]\end{array}$ & & $\begin{array}{l}\text { affected by expectations and selt- } \\
\text { evaluation of progress. }\end{array}$ \\
\hline $\begin{array}{l}\text { O'Brien et al. } \\
(2008)\end{array}$ & $\begin{array}{l}\text { Indicators of success for partici- } \\
\text { pants varied: Participants said they } \\
\text { used several methods to judge } \\
\text { whether they were progressing in } \\
\text { the programme or not. [U] }\end{array}$ & $\begin{array}{l}\text { "I did feel that I was working as I } \\
\text { went through the bands, the stron- } \\
\text { ger bands, that, yeah, it did seem to } \\
\text { get easier as I went along, particu- } \\
\text { larly with the legs. Much easier." } \\
\text { (Participant 12), pg } 1354 \text { [U] }\end{array}$ & & \\
\hline $\begin{array}{l}\text { Pretzer Aboff } \\
\text { et al. }(2009)\end{array}$ & $\begin{array}{l}\text { Personality components: Partici- } \\
\text { pants spoke of personality traits } \\
\text { that promoted independence in } \\
\text { physical activities such as resil- } \\
\text { ience, determination, need for inde- } \\
\text { pendence, denial of need for } \\
\text { assistance, and humour. [U] }\end{array}$ & $\begin{array}{l}\text { "I don't ever call for help, really. I } \\
\text { try to stay independent." Participant } \\
\text { no pg no. }[\mathrm{U}]\end{array}$ & & \\
\hline $\begin{array}{l}\text { Houston } \\
\text { et al. (2015) }\end{array}$ & $\begin{array}{l}\text { Participant expressed what was } \\
\text { important to them personally in } \\
\text { maintaining a good quality of life } \\
\text { [C] }\end{array}$ & $\begin{array}{l}\text { "Having confidence to do things/ } \\
\text { having the ability to keep doing } \\
\text { interesting activities /having move- } \\
\text { ment capability and stability/being } \\
\text { around loved ones/having a religious } \\
\text { belief." Author pg } 25 \text { [C] }\end{array}$ & $\begin{array}{l}\text { 3.2 Participants report individual prefer- } \\
\text { ences for the setting for PA. Tailored } \\
\text { goals and self-evaluation of progress are } \\
\text { important considerations for their } \\
\text { engagement. }\end{array}$ & \\
\hline $\begin{array}{l}\text { Khalil et al. } \\
\text { (2016) }\end{array}$ & $\begin{array}{l}\text { Setting-related issues: location of } \\
\text { the exercise was considered impor- } \\
\text { tant for the participants to engage } \\
\text { in an exercise program with some } \\
\text { preferring home and others hospi- } \\
\text { tal [C] }\end{array}$ & $\begin{array}{l}\text { "The commitment to the program will } \\
\text { be better if it is at the hospital and } \\
\text { under the supervision of a therapist. At } \\
\text { home, you may get busy with other } \\
\text { stuff; defer the exercises and end- up } \\
\text { of not doing them." P1 pg } 514 \text { [C] }\end{array}$ & & \\
\hline $\begin{array}{l}\text { O'Brien et al. } \\
\text { (2016) }\end{array}$ & $\begin{array}{l}\text { Identifying goals: participants had } \\
\text { their own individual goals, therefore } \\
\text { each participant had different goals } \\
\text { and expectations from the program } \\
\text { and these were often different from } \\
\text { the physiotherapists' goals. [C] }\end{array}$ & $\begin{array}{l}\text { "I believe that at my stage of } \\
\text { Parkinson's progress that I have to } \\
\text { be concerned about power and bal- } \\
\text { ance.". P6 Pg } 6 \text { [C] }\end{array}$ & & \\
\hline
\end{tabular}


Table 2: (Continued)

\begin{tabular}{|c|c|c|c|c|}
\hline Author (date) & Findings & Illustration & Categories & Synthesized findings \\
\hline $\begin{array}{l}\text { O'Brien et al. } \\
\text { (2016) }\end{array}$ & $\begin{array}{l}\text { Evaluating if expectations are met: } \\
\text { and the outcome of this evaluation } \\
\text { was continually changing. [C] }\end{array}$ & $\begin{array}{l}\text { "You can get disappointed if you } \\
\text { can't do it. P1 The effort really } \\
\text { means a lot, but I just sort of glided } \\
\text { it through somehow to get it fin- } \\
\text { ished ... I didn't do it to my } \\
\text { satisfaction." P3 pg } 6 \text { [C] }\end{array}$ & & \\
\hline $\begin{array}{l}\text { Quinn et al. } \\
\text { (2010) }\end{array}$ & $\begin{array}{l}\text { Barrier: location of exercise Life- } \\
\text { style issues - some of the clients } \\
\text { preferred doing exercises at home } \\
\text { rather than going to the gym, } \\
\text { because it would fit better with } \\
\text { their lifestyle. [U] }\end{array}$ & $\begin{array}{l}\text { PD2: "I tend to exercise at home } \\
\text { rather than going to the gym } \\
\text { because it fits in with my lifestyle } \\
\text { really. At the weekend I have my } \\
\text { granddaughter and also I am work- } \\
\text { ing three times a week." Table III } \\
\text { pg } 922 \text { [U] }\end{array}$ & & \\
\hline $\begin{array}{l}\text { Crizzle et al. } \\
\text { (2012) }\end{array}$ & $\begin{array}{l}\text { Reassurance from instructor: was } \\
\text { an important motivator of exercise } \\
\text { adherence. }[\mathrm{U}]\end{array}$ & $\begin{array}{l}\text { P4 "A few people started off better } \\
\text { than me... and that bothered me. } \\
\text { But the instructor told me not to } \\
\text { worry about it and that I should } \\
\text { work at my own pace. I didn't think } \\
\text { I could do it. I nearly gave up. But } \\
\text { the leader always insisted that I } \\
\text { could do it, so I had to prove myself } \\
\text { and then I could." pg180 [U] }\end{array}$ & \multirow[t]{5}{*}{$\begin{array}{l}\text { 4.1 Reassurance and support from group } \\
\text { members, instructor, partner or family } \\
\text { are important for participation in PA, } \\
\text { while the use of music enhances enjoy- } \\
\text { ment. }\end{array}$} & \multirow{7}{*}{$\begin{array}{l}\text { 4. External factors can affect parti- } \\
\text { cipants' experience of PA. Involve- } \\
\text { ment of family members/friends } \\
\text { and use of music make sessions } \\
\text { enjoyable, and increases wellbeing. } \\
\text { Support from instructors to ensure } \\
\text { PA programs are structured and } \\
\text { simple to undertake, to explain the } \\
\text { relevance of activities and to sup- } \\
\text { port progression gives participants } \\
\text { confidence and enhances their par- } \\
\text { ticipation. }\end{array}$} \\
\hline $\begin{array}{l}\text { Houston } \\
\text { et al. (2015) }\end{array}$ & $\begin{array}{l}\text { Fluency of movement: participants } \\
\text { have a perception that music helps } \\
\text { people to move in a more fluid and } \\
\text { coordinated fashion. }[\mathrm{U}]\end{array}$ & $\begin{array}{l}\text { "The dance made me feel more } \\
\text { graceful, moving and flowing with } \\
\text { the music, it made me feel that I } \\
\text { had to move when the music } \\
\text { started." P pg } 19 \text { [U] }\end{array}$ & & \\
\hline $\begin{array}{l}\text { Kahil et al. } \\
\text { (2017) }\end{array}$ & $\begin{array}{l}\text { Continuous monitoring: Partici- } \\
\text { pants perceived the importance of } \\
\text { initial instructional sessions and the } \\
\text { weekly phone calls as important } \\
\text { elements for initial adoption of the } \\
\text { program and also for continuation; } \\
\text { they were perceived as important } \\
\text { aspects of the program to build } \\
\text { self-efficacy [C] }\end{array}$ & $\begin{array}{l}\text { "I really prefer doing the exercises } \\
\text { at home ... the sessions with thera- } \\
\text { pist were very important to know } \\
\text { what I am supposed to do and to } \\
\text { build confidence." (table } 4 \text { no page } \\
\text { no.) [C] }\end{array}$ & & \\
\hline $\begin{array}{l}\text { Kunkel et al. } \\
\text { (2017) }\end{array}$ & $\begin{array}{l}\text { Views on the experience on being } \\
\text { partnered with their spouse or vol- } \\
\text { unteer: participants who danced } \\
\text { with their spouse or somebody else } \\
\text { they knew well, appreciated not } \\
\text { only the practical convenience but } \\
\text { also the sense of "moral support" } \\
\text { and shared enjoyment that this } \\
\text { afforded them [U] }\end{array}$ & $\begin{array}{l}\text { Person with Parkinson's: “I } \\
\text { wouldn't have liked, I wouldn't } \\
\text { have gone if [husband] hadn't have } \\
\text { been my partner I don't think. I } \\
\text { liked that very much, I liked it a } \\
\text { lot." [Brenda: F, age } 81 \text {, BLOCK } 3 \\
\text { pg3 [U] }\end{array}$ & & \\
\hline $\begin{array}{l}\text { Pretzer Aboff } \\
\text { et al. (2009) }\end{array}$ & $\begin{array}{l}\text { Environmental Factors: including } \\
\text { the social support network, mem- } \\
\text { bers of the healthcare team, and } \\
\text { the physical environment were } \\
\text { identified as either facilitating or } \\
\text { challenging the person's day-to-day } \\
\text { ability to function [C] }\end{array}$ & $\begin{array}{l}\text { "Participants noticed that small } \\
\text { spaces, clutter, and stairs decreased } \\
\text { mobility." Author no page no. [C] }\end{array}$ & & \\
\hline $\begin{array}{l}\text { Bassett et al. } \\
\text { (2012) }\end{array}$ & $\begin{array}{l}\text { Experience of the Nordic Walking } \\
\text { programme: The progressive man- } \\
\text { ner in which the walking phases } \\
\text { were implemented gave the partici- } \\
\text { pant confidence with her walking: } \\
{[\mathrm{U}]}\end{array}$ & $\begin{array}{l}\text { "Starting on flat surfaces first, that } \\
\text { are not near road traffic - like at the } \\
\text { park and university grounds, meant/ } \\
\text { could concentrate on Nordic walk- } \\
\text { ing; I didn't need to think about } \\
\text { where I was going... That helped } \\
\text { with my confidence so that I was } \\
\text { not distracted by all the road noises } \\
\text { and people going past. After six } \\
\text { weeks, I became less conscious of } \\
\text { the poles; I did not need to think all } \\
\text { the time about how to walk with } \\
\text { them. The poles became an exten- } \\
\text { sion of my arms. Once I had mas- } \\
\text { tered all of what is involved, I found } \\
\text { I was self-correcting and walking } \\
\text { quite confidently." p120 [U] }\end{array}$ & \multirow[t]{2}{*}{$\begin{array}{l}\text { 4.2 Supervision from an instructor who } \\
\text { can provide education on the benefits of } \\
\text { exercise as well as prescribe and progress } \\
\text { exercises enhances participation. }\end{array}$} & \\
\hline $\begin{array}{l}\text { Houston } \\
\text { et al. }(2015)\end{array}$ & $\begin{array}{l}\text { Cognitive Functioning: Participants } \\
\text { find the dance classes to be quite } \\
\text { difficult with respect to remember- } \\
\text { ing the movement sequences and } \\
\text { being able to move different parts } \\
\text { of the body simultaneously. [C] }\end{array}$ & $\begin{array}{l}\text { "I do think it is good for you. The } \\
\text { whole mental activity is on a differ- } \\
\text { ent plane from physical activity." } \\
\text { Participant pg } 25 \text { [C] }\end{array}$ & & \\
\hline
\end{tabular}


Table 2: (Continued)

\begin{tabular}{|c|c|c|c|c|}
\hline Author (date) & Findings & Illustration & Categories & Synthesized findings \\
\hline $\begin{array}{l}\text { Khalil et al. } \\
\text { (2017) }\end{array}$ & $\begin{array}{l}\text { Social interaction and relation with } \\
\text { the therapist: was a strong motiva- } \\
\text { tor to adhere to the program. [U] }\end{array}$ & $\begin{array}{l}\text { "For the first time ever I felt that } \\
\text { someone was truly taking care of } \\
\text { me that was the best piece of the } \\
\text { intervention. It made me feel in turn } \\
\text { that I should take care of myself by } \\
\text { committing to the exercise program. } \\
\text { The therapist was an excellent moti- } \\
\text { vator." (table } 4 \text { no page no.) [U] }\end{array}$ & & \\
\hline $\begin{array}{l}\text { Quinn et al. } \\
\text { (2010) }\end{array}$ & $\begin{array}{l}\text { Setting targets and having knowl- } \\
\text { edge of benefits of exercise: Clients } \\
\text { felt that their understanding of the } \\
\text { relevance and usefulness of exer- } \\
\text { cises was most critical to determin- } \\
\text { ing whether or not they } \\
\text { participated. [U] }\end{array}$ & $\begin{array}{l}\text { PD5: "I think it should be clear how } \\
\text { the exercises fit into the program. } \\
\text { That's helpful. If I feel that the } \\
\text { exercises make a difference, then I } \\
\text { can do them more. Also having the } \\
\text { general idea of the benefits of doing } \\
\text { the exercise. I think the exercise is } \\
\text { good for me and by doing the } \\
\text { exercise I appreciate that there is a } \\
\text { difference." Table III pg } 923 \text { [U] }\end{array}$ & & \\
\hline $\begin{array}{l}\text { Khalil et al. } \\
\text { (2017) }\end{array}$ & $\begin{array}{l}\text { Enablers: Participants reported that } \\
\text { DVD was very clear, easy to follow } \\
\text { and provided an important tool to } \\
\text { continue performing the exercises } \\
\text { independently at home }[\mathrm{U}]\end{array}$ & $\begin{array}{l}\text { "The DVD was simple and easy to } \\
\text { follow its use at home was a strong } \\
\text { motivator to continue doing the } \\
\text { exercises." (table } 4 \text { no page no.) [U] }\end{array}$ & \multirow[t]{2}{*}{ 4.3 Simplicity of exercise programs. } & \\
\hline $\begin{array}{l}\text { Quinn et al. } \\
\text { (2010) }\end{array}$ & Simplicity of exercise program. $[\mathrm{U}]$ & $\begin{array}{l}\text { PD5: "Sessions with physiotherapist } \\
\text { actually taking me through with the } \\
\text { exercises; that is good I think. They } \\
\text { gave me exercises to do at home, } \\
\text { but I have not continued using them } \\
\text { because of a couple of things actu- } \\
\text { ally. For back exercises there was no } \\
\text { standard to do them. So, you do a } \\
\text { lot and a lot of exercises like the } \\
\text { hand behind the shoulder or the } \\
\text { hand in front but actually you do } \\
\text { not know what for the exercises are } \\
\text { and the differences are tricky.... I } \\
\text { think exercises should be simple and } \\
\text { clear how they fit into the program. } \\
\text { That's helpful.". Table III } 923 \text { [U] }\end{array}$ & & \\
\hline
\end{tabular}

$\mathrm{U}$, Unequivocal finding; C, credible finding; PD, Parkinson's disease; PA, physical activity; QOL, quality of life; ADL, activities of daily living.

a big issue. I was therefore not moving ... Now my mobility has improved dramatically ... I feel as if I have regained a big chunk of my life $e^{, 61(p 25)}$

"My health is my priority and if exercise could belp then I will exercise daily. I really would like to reach that level of doing things by my own and not relying on others; this is all what I want." $57(p 515)$

Category 5.2: Personal desire to maintain function and/or slow progression of symptoms is a key motivator for continued participation in PA.

Participants perceived that undertaking PA could slow down and/or control the progression of the disease as well as ameliorate the disease symptoms associated with it. Moreover, PA was viewed by participants as a way of maintaining their self-image as an active and independent person.
"And... then it's my goal to try to keep myself ...keep myself on the go as long as possible so that I ... yes, to be part of life. Not only to sit on a park-bench and... hear somebody talk ... but... to be active as well as I can."

"I have no other answers with this, with this disease... it's something I want to try and fight... and I don't know how to fight it [pause]. I don't want to be overmedicated. I'm hoping exercise can flat line it or slow down the progression or help me. I don't know. So it's mainly my decision to [participate in physical activity]. "30(p1933)

Category 5.3: Personal obligation to oneself and to supportive others ensures a commitment to exercise.

Participants expressed a view of personal accountability for maintaining their health and 
wellbeing. This was reinforced by education on the benefits of PA, which was provided by instructors. This obligation was enhanced further by commitment to undertake PA with a supportive other, such as an instructor.

"I think having a commitment to meet someone at a specific planned time was most important. Let's face it; what I really felt like doing some mornings was to stay in bed! It would have been easy to make excuses to myself if I did not know I had to meet you., $52(p 120)$

"One tried to do (exercise) as well as one can in everything and... doesn't try to waste time in any way but tries to do as well as possible... because the doctor said that. exercise is very important for everybody... for everybody who has Parkinson's disease... so I mustn't become an idler so...out and. . yes walk a lot with poles to keep up the agility in arms and shoulders.",44(p2241)

\section{Synthesized finding 6}

Participants report that personal characteristics such as exercise habit, information seeking, resilience, problem solving and interest in the activity are motivators for engagement. However, lack of time, low outcome expectations and cultural challenges are seen as barriers. Comparisons with others can be a motivator or barrier to engagement.

This synthesized finding was derived from 12 findings and three categories.

Category 6.1: Favorable or unfavorable comparison with others can be a motivator or barrier to engagement.

People with Parkinson's identified that they made comparisons with others in the group based on age, disease severity and concomitant ability. These comparisons could be both beneficial and detrimental. For some people, comparisons with others in the group aided the motivation to match the level of function of fellow group members. However where comparisons were less favorable with the group, in terms of age and disease severity, this could be a barrier to engagement.
"That was an incentive for me to put more into it because I could see that one guy in particular was benefitting from it.",45(p6)

"I went a couple times but they're all, I hate to say it, quite elderly and that for me personally is very depressing... They're all a lot worse because they've had it longer so they're very few young people.... So, we went to the social group but it's like being at a seniors' center... so I haven't gone after.... It is really depressing to see what you have to look forward to becoming., $30(p 1932)$

Category 6.2: Motivation for participation is influenced by personal characteristics.

Participants identified a number of personal traits or characteristics that promoted engagement in PA. These included previous positive experience of PA, ability to problem solve, resilience and self-advocacy. Participants were eager to maintain their roles in life and to be viewed as a valuable member of society.

"...one was out running and doing aerobics and... such things. I used to participate in those gymnastic displays we had at that time... and that was fun...of course that was a driving force... (...) and there the habit too... (to exercise).,"44(p2240)

"Unless you are lucky enough to have a nurse practitioner like - - or you find a good physical therapist, you have to be an advocate, you have to say 'I want physical therapy, what can you write me a prescription for? I want to go and be evaluated about how to use a car or I want to learn about how to get my oxygen better'... so I feel that you have to gather information, you have to be an advocate and tell them what you want and hope that you have a good circle of family and friends." 58(p42)

"It is typically a matter of identifying the right exercises on each occasion to alleviate the various neuro-muscular afflictions. For my shoulder I noted during the classes that the "lasso, arrow and sword' provided some temporary relief - so, I used a similar routine at home to improve mobility and it seems to work better than 
anything else I have tried (e.g. stretching and strengthening).,"47(p26)

Category 6.3: Barriers to participation in PA include lack of outcome expectation, lack of time and cultural challenges.

Participants identified a number of personal factors that influenced participation in PA, such as lack of time due to work and/or family commitments, and a belief by some individuals that they were active enough. As reflected in the second quote, participants living in Jordan reported specific cultural challenges in that older people are not expected to be physically active in Arabic countries.

"I feel I am physically better than other people... and the nature of my work requires a lot of movements. I work as a plumber; hence I move all the time."

"At home [Jordan] I have the fear that my sons will comment on this. I am trying to avoid this. I did though all the sessions with the therapist in the clinic but did not do the sessions at bome.",61(p25)

\section{Synthesized finding 7}

Difficulty obtaining an initial diagnosis, accessibility of services, disease symptoms (both physical and psychological) and severity all impact on pwPD's ability and desire to undertake PA.

This synthesized finding was derived from 15 findings and two categories.

Category 7.1: Both mental and physical disease specific symptoms are barriers to participation in PA.

Participants with Parkinson's disease identified disease specific barriers, such as stiffness, bradykinesia, fatigue and depression which influenced their motivation and ability to participate in regular exercise programs.

"Having the disease does influence my ability to exercise, because I think it is hard to concentrate. So focusing is difficult and also the tiredness and fatigue is another problem." $56($ (p922)

"Since I've been diagnosed with PD and I felt low... I became less motivated to do anything in life ... even when you invited me to do the exercises I felt apathetic ${ }^{\text {,61(p26) }}$

"You've got to battle with willpower all the time.",45(p5)

Category 7.2: Participants identify difficulty gaining a diagnosis as well as lack of referrals to physiotherapy, lack of information about the benefits of exercise which are compounded by a lack of services, and problems with access as barriers to participation.

Participants identified that gaining a diagnosis of Parkinson's disease took a significant amount of time and was not always straightforward due to the insidious nature of the disease symptoms. Those in the early stages of Parkinson's disease were not eager to embrace the diagnosis of a neurological disease. Participants noted that information on the benefits of PA was not generally discussed by the neurologist, nor were they referred to physiotherapists for advice and management of their condition. Participants reported a number of challenges with regard to access and availability of facilities that were suitable for their needs. These ranged from financial issues to physically getting to the facility and the accessibility of the environment once there.

"I started to feel symptoms 6 years ago but I have only been diagnosed 2 years later. I was complaining of general slowness of movement and fatigue; simple things would become difficult. The GP excluded PD as it did not fit with my age category, However I doubted it was PD, as the symptoms were similar to my father's, who is also a PD patient. When other symptoms started to appear like tremor, the GP decided to refer me to a specialized neurologist.

“[My] GP really didn't say much. Actually, neither doctor really encouraged [physical activity]. They didn't discourage it, but they didn't really come out and say, 'You should join this,' or 'You should do that.' There's probably a little bit more work that could be done there to keep people active.",30(pg 1931)

"I had not any advice as to exercises. We picked up some leaflets at one time in the doctor's surgery, from the PD society, but I don't think there was anything in there that referred to 
specific exercises or something that was relevant to me". 56(pg922)

"As you know I come from a distance and my participation would have been impossible without covering the transportation costs that was really important aspect." $61(p 25$.

Table 3 provides a summary of the results of the metasynthesis of the research findings under Objective 2 .
Objective 3: Identify, from the perspective of pWPD, the impact of support mechanisms and behavior change interventions in maintaining participation in PA

\section{Synthesized finding 8}

Participants report that group members, family, friends and co-workers provide support for them to initiate and sustain PA.

This synthesized finding was derived from 13 findings and three categories.

Table 3: Findings, illustrations, categories and synthesized finding (Objective 2: explore barriers and enablers to physical activity for people with Parkinson's disease)

\begin{tabular}{|c|c|c|c|c|}
\hline $\begin{array}{l}\text { Author } \\
\text { (date) }\end{array}$ & Findings & Illustration & Categories & Synthesized finding \\
\hline $\begin{array}{l}\text { Khalil et al. } \\
\text { (2017) }\end{array}$ & $\begin{array}{l}\text { Perceived improvement: whether in } \\
\text { physical or mental status was a key to } \\
\text { motivate them to adhere to the exer- } \\
\text { cise program [C] }\end{array}$ & $\begin{array}{l}\text { "The exercise program has affected me } \\
\text { both mentally and physically before I } \\
\text { got to know you and was introduced } \\
\text { to this program I used to lock myself } \\
\text { away at home fear of falling was a big } \\
\text { issue. I was therefore not moving ... } \\
\text { Now my mobility has improved dra- } \\
\text { matically ... I feel as If I have regained } \\
\text { big chunk of my life." (table 4) [C] }\end{array}$ & \multirow[t]{4}{*}{$\begin{array}{l}\text { 5.1 Perceived improvement in } \\
\text { wellbeing and physical activity } \\
\text { aids motivation to participate } \\
\text { in PA. }\end{array}$} & \multirow[t]{8}{*}{$\begin{array}{l}\text { 5. A personal desire to maintain } \\
\text { independence and a belief that } \\
\text { physical activity can slow deterio- } \\
\text { ration are driving forces for par- } \\
\text { ticipation. Motivation is enhanced } \\
\text { by perceived improvement in } \\
\text { symptoms and feelings of account- } \\
\text { ability to oneself or others. }\end{array}$} \\
\hline $\begin{array}{l}\text { Khalil et al. } \\
\text { (2016) }\end{array}$ & $\begin{array}{l}\text { Outcome expectations: positively } \\
\text { affect the participant's decision about } \\
\text { getting engaged in a future exercise } \\
\text { program [U] }\end{array}$ & $\begin{array}{l}\text { "My health is my priority and if exer- } \\
\text { cise would help then I will exercise } \\
\text { daily. I really would like to reach that } \\
\text { level of doing things by my own and } \\
\text { not relying on others; this is all what I } \\
\text { want." P4 pg } 515 \text { [U] }\end{array}$ & & \\
\hline $\begin{array}{l}\text { Sheehy et al. } \\
\text { (2014) }\end{array}$ & $\begin{array}{l}\text { Physical ability: participants identified } \\
\text { improvements in physical competence } \\
\text { post programme [C] }\end{array}$ & $\begin{array}{l}\text { "I wanted to do everything I could to } \\
\text { delay, I think, keep active and delay if, } \\
\text { if possible any progression" (Fiona) } \\
\text { participant page } 32[\mathrm{C}]\end{array}$ & & \\
\hline $\begin{array}{l}\text { Quinn et al. } \\
\text { (2010) }\end{array}$ & Benefits of group exercise. [U] & $\begin{array}{l}\text { PD4: "I think if you want to do the } \\
\text { exercise by yourself, it will be very } \\
\text { difficult to motivate yourself. If you } \\
\text { were in a class which is not necessarily } \\
\text { a class of Parkinson's but a class of } \\
\text { people in the same fitness range as you } \\
\text { and it is organized in a daily or weekly } \\
\text { basis, you can along with it. There is } \\
\text { the social aspect as well." table III pg } \\
922 \text { [U] }\end{array}$ & & \\
\hline $\begin{array}{l}\text { Bognar et al. } \\
(2016)\end{array}$ & $\begin{array}{l}\text { Dance and the body: participants } \\
\text { reported a desire to maintain their } \\
\text { current functional status and to slow } \\
\text { physical deterioration as motivation } \\
\text { for continued participation [C] }\end{array}$ & $\begin{array}{l}\text { "It has led to some fluidity, which } \\
\text { might not have been there in the body } \\
\text { earlier." [P1] pg4 [C] }\end{array}$ & \multirow[t]{4}{*}{$\begin{array}{l}\text { 5.2 Personal desire to maintain } \\
\text { function and or slow progres- } \\
\text { sion of symptoms is a key } \\
\text { motivator for continued partic- } \\
\text { ipation in PA. }\end{array}$} & \\
\hline $\begin{array}{l}\text { Erikson et al. } \\
\text { (2013) }\end{array}$ & $\begin{array}{l}\text { Have to keep on moving: was a } \\
\text { driving force for exercise, emanating } \\
\text { from sustaining self-image, believing } \\
\text { in the benefits of keeping oneself } \\
\text { active was the underlying construct } \\
{[\mathrm{U}]}\end{array}$ & $\begin{array}{l}\text { "And... then it's my goal to try to } \\
\text { keep myself ... keep myself on the go as } \\
\text { long as possible so that I ... yes, to be } \\
\text { part of life. Not only to sit on a park- } \\
\text { bench and ...hear somebody talk ... but } \\
\text {... to be active as well as I can..." } \\
\text { participant pg } 2241 \text { [U] }\end{array}$ & & \\
\hline $\begin{array}{l}\text { O'Brien et al. } \\
\text { (2008) }\end{array}$ & $\begin{array}{l}\text { Motivators for participation were } \\
\text { broader than just physical outcomes: } \\
\text { they gave a number of reasons for } \\
\text { why they chose to take part in the } \\
\text { study [C] }\end{array}$ & $\begin{array}{l}\text { Participant } 1: \text { " }[I] \text { was keen to try and } \\
\text { assist the program as a participant for } \\
\text { the sake of future generations of PD } \\
\text { sufferers.". Pg } 1353[\mathrm{C}]\end{array}$ & & \\
\hline $\begin{array}{l}\text { O'Brien et al. } \\
\text { (2016) }\end{array}$ & $\begin{array}{l}\text { Focusing on not losing more: adapting } \\
\text { to loss of physical ability also involved } \\
\text { focusing on what participants could } \\
\text { do and trying to prevent further } \\
\text { losses. [U] }\end{array}$ & $\begin{array}{l}\text { "I'm just trying to hold on to what I } \\
\text { have. I mean I am quite old. I really } \\
\text { felt that I must not overburden the } \\
\text { body." P2 pg } 4[\mathrm{U}]\end{array}$ & & \\
\hline
\end{tabular}


Table 3: (Continued)

\begin{tabular}{|c|c|c|c|c|}
\hline $\begin{array}{l}\text { Author } \\
\text { (date) }\end{array}$ & Findings & Illustration & Categories & Synthesized finding \\
\hline $\begin{array}{l}\text { Ravenek } \\
\text { et al. (2009) }\end{array}$ & $\begin{array}{l}\text { Perceptions of control: participants } \\
\text { viewed physical activity as a means to } \\
\text { slow the progression of the disease, } \\
\text { and help maintain their independence } \\
{[\mathrm{U}]}\end{array}$ & $\begin{array}{l}\text { "I have no other answers with this, } \\
\text { with this disease. .. it's something I } \\
\text { want to try and fight. .. and I don't } \\
\text { know how to fight it [pause]. I don't } \\
\text { want to be overmedicated. I'm hoping } \\
\text { exercise can flatline it or slow down } \\
\text { the progression or help me. I don't } \\
\text { know. So, it's mainly my decision to } \\
\text { [participate in physical activity]." Par- } \\
\text { ticipant pg } 1933 \text { [U] }\end{array}$ & & \\
\hline $\begin{array}{l}\text { Bassett et al. } \\
(2012)\end{array}$ & $\begin{array}{l}\text { Experience of the Nordic Walking } \\
\text { programme: Walking with a desig- } \\
\text { nated person enhanced commitment } \\
{[\mathrm{U}]}\end{array}$ & $\begin{array}{l}\text { "I think having a commitment to meet } \\
\text { someone at a specific planned time was } \\
\text { most important. Let's face it; what I } \\
\text { really felt like doing some mornings } \\
\text { was to stay in bed! It would have been } \\
\text { easy to make excuses to myself if I did } \\
\text { not know I had to meet you." Partici- } \\
\text { pant pg } 120[\mathrm{U}]\end{array}$ & \multirow[t]{3}{*}{$\begin{array}{l}\text { 5.3 Personal obligation to one- } \\
\text { self and supportive others } \\
\text { ensures a commitment to exer- } \\
\text { cise. }\end{array}$} & \\
\hline $\begin{array}{l}\text { Erikson et al. } \\
\text { (2013) }\end{array}$ & $\begin{array}{l}\text { One should see to one's health: a } \\
\text { knowledge-driven obligation towards } \\
\text { oneself and toward supportive signifi- } \\
\text { cant others and health professional, } \\
\text { that exercise is necessary to good } \\
\text { health. [U] }\end{array}$ & $\begin{array}{l}\text { "One tried to do (exercise) as well as } \\
\text { one can in everything and ... doesn't } \\
\text { try to waste time in any way but tries } \\
\text { to do as well as possible. ... because } \\
\text { the doctor said that ... exercise is very } \\
\text { important for everybody ... for every- } \\
\text { body who has Parkinson's disease... so } \\
\text { I mustn't become an idler so ...out and } \\
\ldots \text {. yes walk a lot with poles to keep up } \\
\text { the agility in arms and shoulders." } \\
\text { Participant pg } 2241[\mathrm{U}]\end{array}$ & & \\
\hline $\begin{array}{l}\text { Erikson et al. } \\
\text { (2013) }\end{array}$ & $\begin{array}{l}\text { Taking responsibility for own health: } \\
\text { generated from the decision making } \\
\text { that preceded start to exercise and } \\
\text { included the decision to believe in the } \\
\text { good effect of exercise and the coun- } \\
\text { teracting effective of a passive lifestyle } \\
\text { [C] }\end{array}$ & $\begin{array}{l}\text { "... and then its only making the best of } \\
\text { the situation... one mustn't think nega- } \\
\text { tively, one has to try to avoid that... } \\
\text { think positively, try turning everything } \\
\text { into the best instead." Participant pg } \\
2241 \text { [C] }\end{array}$ & & \\
\hline $\begin{array}{l}\text { O'Brien et al. } \\
\text { (2016) }\end{array}$ & $\begin{array}{l}\text { Comparing oneself with others in the } \\
\text { exercise group: was another aspect of } \\
\text { exercising in a group of people with } \\
\text { PD.[U] }\end{array}$ & $\begin{array}{l}\text { "That was an incentive for me to put } \\
\text { more into it because I could see that } \\
\text { one guy in particular was benefitting } \\
\text { from it." P6 pg } 6[\mathrm{U}]\end{array}$ & \multirow[t]{3}{*}{$\begin{array}{l}\text { 6.1 Favourable or unfavour- } \\
\text { able comparison with others } \\
\text { can be a motivator or barrier } \\
\text { to engagement. }\end{array}$} & \multirow[t]{4}{*}{$\begin{array}{l}\text { 6. Participants report that per- } \\
\text { sonal characteristics such as exer- } \\
\text { cise habit, information seeking, } \\
\text { resilience, problem solving and } \\
\text { interest in the activity are motiva- } \\
\text { tors for engagement. However, } \\
\text { lack of time, low outcome expec- } \\
\text { tations and cultural challenges are } \\
\text { seen as barriers. Comparisons } \\
\text { with others can be a motivator or } \\
\text { barrier to engagement. }\end{array}$} \\
\hline $\begin{array}{l}\text { Ravenek } \\
\text { et al. (2009) }\end{array}$ & $\begin{array}{l}\text { Social support groups: An important } \\
\text { factor contributing to the perceived } \\
\text { suitability of these groups for partici- } \\
\text { pants was the variability in disease } \\
\text { progression of group members. When } \\
\text { participants were not able to relate to } \\
\text { other group members, the support } \\
\text { groups were seen as negative and this } \\
\text { led to attrition. When participants } \\
\text { were able to relate to other group } \\
\text { members, these groups offered a tre- } \\
\text { mendous amount of support. [U] }\end{array}$ & $\begin{array}{l}\text { "I went a couple times [to a support } \\
\text { group] but they're all, I hate to say it, } \\
\text { quite elderly and that for me personally } \\
\text { is very depressing. .. They're all a lot } \\
\text { worse because they've had it longer so } \\
\text { they're very few young people. ... So, } \\
\text { we went to the social group but it's } \\
\text { like being at a senior's centre... so I } \\
\text { haven't gone after... .. It is really } \\
\text { depressing to see what you have to } \\
\text { look forward to becoming." Participant } \\
\text { Pg } 1932 \text { [U] }\end{array}$ & & \\
\hline $\begin{array}{l}\text { Sheehy } \\
(2014)\end{array}$ & $\begin{array}{l}\text { Social comparison: made with others } \\
\text { varied based on disease and ability } \\
\text { and resulted in both positive and } \\
\text { negative emotions [U] }\end{array}$ & $\begin{array}{l}\text { "When you talk to other people then, } \\
\text { that have been doin' this, like, [Marty] } \\
\text { for thirteen years and she's in my class } \\
\text { and they're doin' better than me, much } \\
\text { better than me...I think, we'll see, you } \\
\text { know, there's a good possibility that } \\
\text { thirteen years from now I might be } \\
\text { where I am." (Belle) pg } 33 \text { [U] }\end{array}$ & & \\
\hline $\begin{array}{l}\text { Bognar et al. } \\
(2016)\end{array}$ & $\begin{array}{l}\text { Redefining the self: seeking knowledge } \\
\text { to become proficient in self-manage- } \\
\text { ment }[\mathrm{U}]\end{array}$ & $\begin{array}{l}\text { "Going to class you're not giving } \\
\text { in - you're getting back. You're } \\
\text { getting something to help yourself." } \\
{[\text { Participant } 2] \text { pg } 4[\mathrm{U}]}\end{array}$ & $\begin{array}{l}6.2 \text { Motivation for participa- } \\
\text { tion is influenced by personal } \\
\text { characteristics. }\end{array}$ & \\
\hline
\end{tabular}


Table 3: (Continued)

\begin{tabular}{|c|c|c|c|c|}
\hline $\begin{array}{l}\text { Author } \\
\text { (date) }\end{array}$ & Findings & Illustration & Categories & Synthesized finding \\
\hline $\begin{array}{l}\text { Davis et al. } \\
\text { (2003) }\end{array}$ & $\begin{array}{l}\text { Being a self-advocate was a method of } \\
\text { dealing with the disease. [U] }\end{array}$ & $\begin{array}{l}\text { "Unless you are lucky enough to have } \\
\text { a nurse practitioner like - - or you } \\
\text { find a good physical therapist, you } \\
\text { have to be an advocate, you have to } \\
\text { say 'I want physical therapy, what can } \\
\text { you write me a prescription for? I want } \\
\text { to go and be evaluated about how to } \\
\text { use a car or I want to learn about how } \\
\text { to get my oxygen better'... so I feel } \\
\text { that you have to gather information, } \\
\text { you have to be an advocate and tell } \\
\text { them what you want and hope that } \\
\text { you have a good circle of family and } \\
\text { friends". Participant Pg } 42 \text { [U] }\end{array}$ & & \\
\hline $\begin{array}{l}\text { Erikson et al. } \\
\text { (2013) }\end{array}$ & $\begin{array}{l}\text { Identifying oneself as physically active: } \\
\text { related to the participant definition of } \\
\text { themselves as a physical active person } \\
\text { both in the past and in the present [U] }\end{array}$ & $\begin{array}{l}\text { “...one was out running and doing } \\
\text { aerobics and ... such things. I used to } \\
\text { participate in those gymnastic displays } \\
\text { we had at that time... and that was } \\
\text { fun... of course that was a driving } \\
\text { force... () and there the habit too ... (to } \\
\text { exercise)." participant pg } 2240 \text { [U] }\end{array}$ & & \\
\hline $\begin{array}{l}\text { Erikson et al. } \\
\text { (2013) }\end{array}$ & $\begin{array}{l}\text { Being Part of life: participants } \\
\text { expressed an aim to continue to par- } \\
\text { ticipate in valuable areas of life even if } \\
\text { support was needed for managing to } \\
\text { do so. [C] }\end{array}$ & $\begin{array}{l}\text { "When you aren't disabled... you think } \\
\text { that it's the practical things which } \\
\text { are... the main thing, but it isn't. It's } \\
\text { how you feel inside... and then... then } \\
\text { it's not such a big defeat if you can't } \\
\text { get your shoes on. What I mean with } \\
\text { being part of life, it's probably to be } \\
\text { needed." Participant pg } 2240 \text { [C] }\end{array}$ & & \\
\hline $\begin{array}{l}\text { Houston } \\
\text { et al. }(2015)\end{array}$ & $\begin{array}{l}\text { Aid to daily life: Participants noted } \\
\text { how exercise from class help to allevi- } \\
\text { ate rigidity and pain and improve } \\
\text { mobility for everyday activities. [U] }\end{array}$ & $\begin{array}{l}\text { "It is typically a matter of identifying } \\
\text { the right exercises on each occasion to } \\
\text { alleviate the various neuro-muscular } \\
\text { afflictions. For my shoulder I noted } \\
\text { during the classes that the 'lasso, arrow } \\
\text { and sword' provided some temporary } \\
\text { relief - so, I used a similar routine at } \\
\text { home to improve mobility and it seems } \\
\text { to work better than anything else I } \\
\text { have tried (e.g. stretching and strength- } \\
\text { ening)." participant pg } 26 \text { [U] }\end{array}$ & & \\
\hline $\begin{array}{l}\text { Kahil et al. } \\
\text { (2017) }\end{array}$ & $\begin{array}{l}\text { Personal challenges: comorbidities } \\
\text { such as knee or hip osteoarthritis, } \\
\text { cervical or lumbar disk, limited but } \\
\text { did not prevent them from engaging in } \\
\text { the exercise program. [U] }\end{array}$ & $\begin{array}{l}\text { "I have a chronic problem in my knee } \\
\text { and some of the balance exercises were } \\
\text { causing me more pain ... this did not } \\
\text { stop me from doing the exercise ... the } \\
\text { therapist helped me in modifying the } \\
\text { exercise so that it became more tolera- } \\
\text { ble." (table } 4 \text { no page no.) [U] }\end{array}$ & & \\
\hline $\begin{array}{l}\text { Kahil et al. } \\
\text { (2017) }\end{array}$ & $\begin{array}{l}\text { Lack of outcome expectations: one } \\
\text { participant at early stage believed he } \\
\text { was not necessarily in need for exer- } \\
\text { cise as they were still physically fit. } \\
\text { [C] }\end{array}$ & $\begin{array}{l}\text { "I feel I am physically better than other } \\
\text { people... and the nature of my work } \\
\text { requires a lot of movements. I work as } \\
\text { a plumber; hence I move all the time." } \\
\text { (table } 4 \text { no page no.) [C] }\end{array}$ & $\begin{array}{l}\text { 6.3 Barriers to participation in } \\
\text { PA include lack of outcome } \\
\text { expectation, lack of time and } \\
\text { cultural challenges. }\end{array}$ & \\
\hline $\begin{array}{l}\text { Khalil et al. } \\
\text { (2017) }\end{array}$ & $\begin{array}{l}\text { Cultural challenges: being active is not } \\
\text { the norm particularly for old people. } \\
{[\mathrm{U}]}\end{array}$ & $\begin{array}{l}\text { "At home I have the fear that my sons } \\
\text { will comment on this I am trying to } \\
\text { avoid this. I did though all the sessions } \\
\text { with the therapist in the clinic but did } \\
\text { not do the sessions at home." (table } 4 \\
\text { no page no.) [U] }\end{array}$ & & \\
\hline $\begin{array}{l}\text { Kunkel et al. } \\
\text { (2017) }\end{array}$ & $\begin{array}{l}\text { Views on continuing with dance clas- } \\
\text { ses: all people with Parkinson's } \\
\text { expressed an interest in continuing to } \\
\text { dance but none had made firm } \\
\text { arrangements to do so. [U] }\end{array}$ & $\begin{array}{l}\text { Person with Parkinson's: "I think it, } \\
\text { because I can't walk that far, and I } \\
\text { can't walk that quickly, certainly regu- } \\
\text { lar dancing would take the place of } \\
\text { some of the walking that I can't do." } \\
\text { Elizabeth: age } 71, \text { H\&Y2, pg } 6 \text { [U] }\end{array}$ & & \\
\hline $\begin{array}{l}\text { Kahil et al. } \\
\text { (2017) }\end{array}$ & $\begin{array}{l}\text { Depression: affected motivation to do } \\
\text { anything including getting engaged in } \\
\text { the exercise program. [U] }\end{array}$ & $\begin{array}{l}\text { "Since I've been diagnosed with PD } \\
\text { and I felt low... .I became less motivated } \\
\text { to do anything in life ... even when } \\
\text { you invited me to do the exercises I felt } \\
\text { apathetic." (table } 4 \text { no page no.) [U] }\end{array}$ & $\begin{array}{l}7.1 \text { Both physical and mental } \\
\text { disease specific symptoms are } \\
\text { identified as barriers to partici- } \\
\text { pation in PA. }\end{array}$ & $\begin{array}{l}\text { 7. Difficulty obtaining an initial } \\
\text { diagnosis, accessibility of services, } \\
\text { disease symptoms (both physical } \\
\text { and psychological) and severity all } \\
\text { impact on pwPD's ability and } \\
\text { desire to undertake physical } \\
\text { activity. }\end{array}$ \\
\hline
\end{tabular}


Table 3: (Continued)

\begin{tabular}{|c|c|c|c|c|}
\hline $\begin{array}{l}\text { Author } \\
\text { (date) }\end{array}$ & Findings & Illustration & Categories & Synthesized finding \\
\hline $\begin{array}{l}\text { Kahil et al. } \\
\text { (2017) }\end{array}$ & $\begin{array}{l}\text { Participants perceived that Physical } \\
\text { fatigue would limit but not prevent } \\
\text { them from engaging in the exercise } \\
\text { program. [U] }\end{array}$ & $\begin{array}{l}\text { "I lacked the habit of past exercise. } \\
\text { This is the first time I have been in a } \\
\text { structured program. When I first } \\
\text { started, I used to feel tired even after } \\
\text { performing only a few movements. This } \\
\text { feeling, however, ceased off after few } \\
\text { weeks." Participant (table } 4 \text { no page } \\
\text { no.) [U] }\end{array}$ & & \\
\hline $\begin{array}{l}\text { Khalil et al. } \\
\text { (2016) }\end{array}$ & $\begin{array}{l}\text { Disease-specific issues: such as stiff- } \\
\text { ness and fatigue may limit their poten- } \\
\text { tial participation in future exercise } \\
\text { programs. }[\mathrm{C}]\end{array}$ & $\begin{array}{l}\text { "All the participants reported } \\
\text { experiencing the "wearing off" phe- } \\
\text { nomenon in which these symptoms } \\
\text { become much more apparent." Author } \\
\text { pg } 514[\mathrm{C}]\end{array}$ & & \\
\hline $\begin{array}{l}\text { O'Brien et al. } \\
\text { (2016) }\end{array}$ & $\begin{array}{l}\text { Facing challenges of apathy, fatigue } \\
\text { and other health problems were a } \\
\text { significant barrier to regular exercise } \\
\text { participation. [U] }\end{array}$ & $\begin{array}{l}\text { "You've got to battle with willpower } \\
\text { all the time." P3 pg } 5[\mathrm{U}]\end{array}$ & & \\
\hline $\begin{array}{l}\text { Pretzer Aboff } \\
\text { et al. }(2009)\end{array}$ & $\begin{array}{l}\text { Physiological symptoms: both motor } \\
\text { and non-motor, of PD were noted by } \\
\text { people with PD to limit the ability to } \\
\text { engage in physical and functional } \\
\text { activities. [U] }\end{array}$ & $\begin{array}{l}\text { Another participant described his expe- } \\
\text { rience with bradykinesia: "It is diffi- } \\
\text { cult. I muddle through... . It takes me } \\
\text { forever. .. my speeds have gone from } \\
\text { slow and stop." (no page no.) [U] }\end{array}$ & & \\
\hline $\begin{array}{l}\text { Quinn et al. } \\
\text { (2010) }\end{array}$ & $\begin{array}{l}\text { Disease specific barriers: Participants } \\
\text { with PD, highlighted several factors, } \\
\text { namely stiffness, fatigue and problems } \\
\text { with maintaining concentration. [U] }\end{array}$ & $\begin{array}{l}\text { PD5:"'Having the disease does influ- } \\
\text { ence my ability to exercise, because I } \\
\text { think it is hard to concentrate. So, } \\
\text { focusing is difficult and also the tired- } \\
\text { ness and fatigue is another problem." } \\
\text { pg } 922 \text { [U] }\end{array}$ & & \\
\hline $\begin{array}{l}\text { Sheehy } \\
(2014)\end{array}$ & $\begin{array}{l}\text { Psychological challenges: participants } \\
\text { feared doing a programme which was } \\
\text { unfamiliar and where they may hurt } \\
\text { themselves }[\mathrm{U}]\end{array}$ & $\begin{array}{l}\text { "I had all those kinds of fears. Well, } \\
\text { you know, what if it's like one of those } \\
\text { classes you go into and the person at } \\
\text { the front is saying, no pain, no gain, } \\
\text { and you hurt yourself and then you } \\
\text { can't do anything." (Imelda) pg } 32 \text { [U] }\end{array}$ & & \\
\hline $\begin{array}{l}\text { Davis et al. } \\
\text { (2003) }\end{array}$ & $\begin{array}{l}\text { Health Care issues: the current health } \\
\text { care system does not meet the compre- } \\
\text { hensive needs of individuals with PD. } \\
{[\mathrm{U}]}\end{array}$ & $\begin{array}{l}\text { "It's kind of pitiful that we don't have } \\
\text { outreach with physical therapy, we } \\
\text { have no national, state or local out- } \\
\text { reach programs, look at the table of us, } \\
\text { how much we would improve if we } \\
\text { had one hour of outreach a week." } \\
\text { pg42 [U] }\end{array}$ & \multirow[t]{5}{*}{$\begin{array}{l}\text { 7.2 Participants identify diffi- } \\
\text { culty gaining a diagnosis as } \\
\text { well as lack of referrals to } \\
\text { physiotherapy, lack of informa- } \\
\text { tion about the benefits of exer- } \\
\text { cise which are compounded by } \\
\text { a lack of services, and pro- } \\
\text { blems with access as barriers } \\
\text { to participation. }\end{array}$} & \\
\hline $\begin{array}{l}\text { Kahil et al. } \\
\text { (2017) }\end{array}$ & $\begin{array}{l}\text { Denial of PD diagnosis: participants at } \\
\text { early stage were still in doubt of being } \\
\text { diagnosed of PD. [U] }\end{array}$ & $\begin{array}{l}\text { "I did not do the exercises because I } \\
\text { am still not convinced I have PD ... I } \\
\text { have this dilemma ... I am really not } \\
\text { convinced that I have PD ... next week } \\
\text { I will be seeing another neurologist to } \\
\text { discuss my case." (table } 4 \text { no page no.) } \\
\text { [U] }\end{array}$ & & \\
\hline $\begin{array}{l}\text { Kahil et al. } \\
\text { (2017) }\end{array}$ & $\begin{array}{l}\text { Participants report that compensation } \\
\text { for transportation helped with adher- } \\
\text { ence }[\mathrm{U}]\end{array}$ & $\begin{array}{l}\text { "As you know I come from a distance } \\
\text { and my participation would have been } \\
\text { impossible without covering the trans- } \\
\text { portation costs that was really impor- } \\
\text { tant aspect" (table 4) [U] }\end{array}$ & & \\
\hline $\begin{array}{l}\text { Khalil et al. } \\
\text { (2016) }\end{array}$ & $\begin{array}{l}\text { Difficulty of diagnosis: Participants } \\
\text { with PD reported spending a huge } \\
\text { chunk of time searching for a basic } \\
\text { answer that can justify their symp- } \\
\text { toms: a diagnosis. [U] }\end{array}$ & $\begin{array}{l}\text { "I started to feel symptoms } 6 \text { years } \\
\text { ago, but I have only been diagnosed } 2 \\
\text { years later. I was complaining of gen- } \\
\text { eral slowness of movement and fatigue; } \\
\text { simple things would become difficult. } \\
\text { The GP excluded PD as it did not fit } \\
\text { with my age category, However I } \\
\text { doubted it was PD, as the symptoms } \\
\text { were similar to my father's, who is also } \\
\text { a PD patient. When other symptoms } \\
\text { started to appear like tremor, the GP } \\
\text { decided to refer me to a specialized } \\
\text { neurologist." P5 pg } 512 \text { [U] }\end{array}$ & & \\
\hline $\begin{array}{l}\text { Khalil et al. } \\
\text { (2016) }\end{array}$ & $\begin{array}{l}\text { Lack of informational support by neu- } \\
\text { rologist: about the importance of exer- } \\
\text { cise or physiotherapy to their } \\
\text { condition. }[\mathrm{U}]\end{array}$ & $\begin{array}{l}\text { "I do not do any specific exercises for } \\
\text { managing my condition as I am not } \\
\text { aware of any.. my neurologist has not } \\
\text { mentioned this to me." P9 pg } 513 \text { [U] }\end{array}$ & & \\
\hline
\end{tabular}


Table 3: (Continued)

\begin{tabular}{|l|l|l|l|}
\hline $\begin{array}{l}\text { Author } \\
\text { (date) }\end{array}$ & Findings & Illustration & Categories \\
\hline $\begin{array}{l}\text { Khalil } \text { et al. } \\
(2016)\end{array}$ & $\begin{array}{l}\text { Lack of referrals to physiotherapy: } \\
\text { None of the participants were referred } \\
\text { to physiotherapy for explicit manage- } \\
\text { ment of PD. [U] }\end{array}$ & $\begin{array}{l}\text { "Four years ago I was complaining } \\
\text { from lumbar disk and for that reason } \\
\text { I've been referred to physiotherapy. } \\
\text { The treatment was for my back pain } \\
\text { but not for the PD." P3 pg 514 [U] }\end{array}$ & Synthesized finding \\
\hline $\begin{array}{l}\text { Quinn } \text { et al. } \\
(2010)\end{array}$ & $\begin{array}{l}\text { Lack of information on exercise in PD } \\
\text { [U] }\end{array}$ & $\begin{array}{l}\text { "I had not any advice as to exercises. } \\
\text { We picked up some leaflets at one time } \\
\text { in the doctor's surgery, from the PD } \\
\text { society, but I don't think there was } \\
\text { anything in there that referred to spe- } \\
\text { cific exercises or something that was } \\
\text { relevant to me." Participant pg 922 [U] }\end{array}$ & $\begin{array}{l}\text { "[My] GP really didn't say much. } \\
\text { Actually, neither doctor really encour- } \\
\text { aged [physical activity]. They didn't } \\
\text { discourage it, but they didn't really } \\
\text { come out and say, 'You should join } \\
\text { this, or 'You should do that.' There's } \\
\text { probably a little bit more work that } \\
\text { could be done there to keep people } \\
\text { active." Participant pg 1931 [U] }\end{array}$ \\
\hline $\begin{array}{l}\text { Ravenek } \\
\text { et al. (2009) }\end{array}$ & $\begin{array}{l}\text { Physicians: participants' reports on } \\
\text { GPs and neurologists was the lack of } \\
\text { support provided with regards to } \\
\text { physical activity participation. [U] }\end{array}$ & \\
\hline
\end{tabular}

$\mathrm{U}$, unequivocal finding; $C$, credible fining; PD, Parkinson's disease; PA, physical activity; GP, general practitioner.

Category 8.1: Group PA offers a positive communal experience and provides opportunities for socialization, support and confidence building.

Participants identified significant social and emotional benefits of participating in group PA. Group attendance kept away feelings of isolation and depression as the participants had a common purpose. Participants valued the experience of exercising with others who had PD and with whom they felt a shared experience. Over time, they were able to build a good rapport with each other and were encouraged by seeing improvements in group members' abilities. Participants identified that groups offered the opportunity to support each other and provide advice with regards to their problems. This included learning about the disease from each other and communal problem solving.

"When you get a Parkinson's diagnosis, [you] tend to back into a cage somewhere where nobody can see my weaknesses. You tend to exclude yourself from society. When you join something like Dancing with Parkinson's you become part of a larger group and it's much easier to fight that weakness.... The other classmates are a benefit that I didn't expect or think about at the time." $" 59(p 3)$

'I didn't know anyone with Parkinson's before I came to these classes. I was all alone. It's not just about dancing, it's making friends and sharing., $47(p 27)$

"Very positive communal experience; pleased to see improvements in others."

"[We] exchanged thoughts and notes that we had we all seem to have been on the Internet at various stages, gathering information, and it was very helpful." $46($ (p1355)

Category 8.2: Family support and encouragement to initiate and sustain PA.

Participants identified that family support was an important element which encouraged uptake and engagement in PA. Family support included encouragement and partaking in PA with them.

"Family has always been a source of support for me to accept the disease and to deal with it. A lot of mornings I would be very tired sitting on my sofa or lying in my bed until my son comes and asks me to go for a walk with him. His encouragement pulls me up and it's just about the start that is difficult then I get clicked on; I usually feel much better afterwards."57(p515)

"They encourage me, goad me, embarrass me into doing some [activities] and they also will alter their activities to accommodate me which is 
very good. [My husband] just you know, like he always is trying to get me into doing more. He probably encourages me and gets me going more than I would do myself." 30 (p1929)

Category 8.3: Support and encouragement from friends and co-workers.

Participants reported that friends offered instrumental support in terms of provision of transport and mutual participation in PA. Co-workers were also supportive, for example, in organizing workloads to allow the participants time to attend PA programs.

"They'll come out and walk with me sometimes or friends will come out and bike with me... it's nice to have friends who are compassionate and ab understand what you are going through."

"They were all very supportive because I started [exercising at the research center] when I was still working. So they all made sure, no matter who was working with me that I got off in time."30(p1930)

Table 4 provides a summary of the results of the meta-synthesis of the research findings under Objective 3.

\section{Discussion}

The purpose of this qualitative systematic review was to synthesize the best available evidence of pwPD's experiences of and preferences for PA, their perceived enablers and barriers to engagement, as well as pwPD's views of support mechanisms and behavior change interventions designed to sustain participation. A comprehensive search of the literature yielded 21 studies that met the inclusion criteria. The studies involved both men and women with a diagnosis of PD from different countries and provided data from studies using various qualitative and mixed method designs. The methodological quality of the included studies varied, ranging from over $70 \%$ in 16 studies and over $50 \%$ in four studies, with one study achieving $30 \%$ on the JBI criteria for critical appraisal. ${ }^{40}$ During data extraction, a decision was taken to exclude two studies ${ }^{41,42}$ from further synthesis as they did not provide any illustrations of the participant voice to support their findings. The remaining 19 studies resulted in 105 findings, which were grouped into 20 categories and aggregated into eight synthesized findings.

The review identified that pwPD viewed PA as an enjoyable and positive experience, which could assist in the control of their symptoms and which enhanced their quality of life. However, participation in PA was a challenge due to the individualized,

Table 4: Findings, illustrations, categories and synthesized finding (Objective 3: identify, from the perspective of people with Parkinson's disease, the impact of support mechanisms in maintaining participation in physical activity)

\begin{tabular}{|c|c|c|c|c|}
\hline $\begin{array}{l}\text { Author } \\
\text { (date) }\end{array}$ & Findings & Illustration & Category & Synthesized finding \\
\hline $\begin{array}{l}\text { Bognar et al. } \\
(2016)\end{array}$ & $\begin{array}{l}\text { Connecting through dance: the } \\
\text { need for socialization was articu- } \\
\text { lated as a central motivator for } \\
\text { attending class, as participants } \\
\text { admitted that living with PD could } \\
\text { be isolating. [U] }\end{array}$ & $\begin{array}{l}\text { "When you get a Parkinson's diag- } \\
\text { nosis, [you] tend to back into a } \\
\text { cage somewhere where nobody can } \\
\text { see my weaknesses. You tend to } \\
\text { exclude yourself from society. } \\
\text { When you join something like } \\
\text { Dancing with Parkinson's you } \\
\text { become part of a larger group and } \\
\text { it's much easier to fight that weak- } \\
\text { ness... The other classmates are a } \\
\text { benefit that I didn't expect or think } \\
\text { about at the time." [P9] pg } 3[\mathrm{U}]\end{array}$ & \multirow[t]{3}{*}{$\begin{array}{l}\text { 8.1 Group PA offers a positive com- } \\
\text { munal experience and provides oppor- } \\
\text { tunities for socialization, support and } \\
\text { confidence building. }\end{array}$} & \multirow[t]{3}{*}{$\begin{array}{l}\text { 8. Participants report that group } \\
\text { members, family, friends and co- } \\
\text { workers provide support for them } \\
\text { to initiate and sustain PA. }\end{array}$} \\
\hline $\begin{array}{l}\text { Westheimer } \\
\text { et al. }(2016)\end{array}$ & $\begin{array}{l}\text { Physical social and emotional bene- } \\
\text { fits of the group. }[\mathrm{C}]\end{array}$ & $\begin{array}{l}\text { "Very positive communal experi- } \\
\text { ence; pleased to see improvements } \\
\text { in others participant." pg1266 [C] }\end{array}$ & & \\
\hline $\begin{array}{l}\text { Crizzle et al. } \\
\text { (2012) }\end{array}$ & $\begin{array}{l}\text { Group structure and group sup- } \\
\text { port: participants reported develop- } \\
\text { ing a good rapport with each other } \\
\text { over time and were encouraged by } \\
\text { the improvements made in their } \\
\text { physical and social abilities. [C] }\end{array}$ & $\begin{array}{l}\text { Participant } 1 \text { said (pointing to par- } \\
\text { ticipant } 4 \text { ): "He actual talked to } \\
\text { me later on, at the beginning he } \\
\text { just sat there completely mum." } \\
\text { pg180 [C] }\end{array}$ & & \\
\hline
\end{tabular}


Table 4: (Continued)

\begin{tabular}{|c|c|c|c|c|}
\hline $\begin{array}{l}\text { Author } \\
\text { (date) }\end{array}$ & Findings & Illustration & Category & Synthesized finding \\
\hline $\begin{array}{l}\text { Hislop et al. } \\
\text { (2015) }\end{array}$ & $\begin{array}{l}\text { Confidence building: Attendance at } \\
\text { the group helped build confidence. } \\
{[\mathrm{U}]}\end{array}$ & $\begin{array}{l}\text { "It gives you more confidence to } \\
\text { go out in the world and tackle life. } \\
\text { You know, if you've got a wee } \\
\text { network of people that understand } \\
\text { you..." participant pg } 3[\mathrm{U}]\end{array}$ & & \\
\hline $\begin{array}{l}\text { Houston } \\
\text { et al. }(2015)\end{array}$ & $\begin{array}{l}\text { Motivation to keep coming to the } \\
\text { English National Ballet ENB Dance } \\
\text { for Parkinson's programme were } \\
\text { diverse. [U] }\end{array}$ & $\begin{array}{l}\text { "I didn't know anyone with Par- } \\
\text { kinson's before I came to these } \\
\text { classes. I was all alone. It's not just } \\
\text { about dancing, it's making friends } \\
\text { and sharing." P pg } 27 \text { [U] }\end{array}$ & & \\
\hline $\begin{array}{l}\text { O'Brien et al. } \\
(2008)\end{array}$ & $\begin{array}{l}\text { The participants' experience of a } \\
\text { disease-specific exercise programme } \\
\text { was positive: Benefits included } \\
\text { sharing information about Parkin- } \\
\text { son's disease. [U] }\end{array}$ & $\begin{array}{l}\text { "[We] exchanged thoughts and } \\
\text { notes that we had we all seem to } \\
\text { have been on the Internet at vari- } \\
\text { ous stages, gathering information, } \\
\text { and it was very helpful." (Partici- } \\
\text { pant 4). Pg } 1355 \text { [U] }\end{array}$ & & \\
\hline $\begin{array}{l}\text { O'Brien et al. } \\
\text { (2016) }\end{array}$ & $\begin{array}{l}\text { Relationships with a shared under- } \\
\text { standing: Participants valued the } \\
\text { experience of exercising with } \\
\text { others with PD. Having a common } \\
\text { purpose and a shared understand- } \\
\text { ing were common themes. [U] }\end{array}$ & $\begin{array}{l}\text { "It's not that you want sympathy } \\
\text { but understanding. So, when you're } \\
\text { down there (referring to the group) } \\
\text { I actually totally relax because we } \\
\text { are all understanding each other." } \\
\text { P2 pg6 [U] }\end{array}$ & & \\
\hline $\begin{array}{l}\text { Sheehy } \\
\text { (2014) }\end{array}$ & $\begin{array}{l}\text { Social support: centred around the } \\
\text { varied types of support given and } \\
\text { received by participants [C] }\end{array}$ & $\begin{array}{l}\text { "I just kinda take it upon me, you } \\
\text { know, if I see somebody not doin' } \\
\text { what they, you know, need to be } \\
\text { doin' or goin' in the wrong direc- } \\
\text { tion, I, I just feel like I should help } \\
\text { out." (Albert) pg34 [C] }\end{array}$ & & \\
\hline $\begin{array}{l}\text { Kahil et al. } \\
\text { (2017) }\end{array}$ & $\begin{array}{l}\text { Family support: encouragement } \\
\text { provided by family members was } \\
\text { perceived to be important. [U] }\end{array}$ & $\begin{array}{l}\text { "The family encouragement was } \\
\text { very important for me to take this } \\
\text { step and start the exercise program } \\
\text { with you." (Table } 4 \text { no page no.) } \\
\text { [U] }\end{array}$ & \multirow[t]{3}{*}{$\begin{array}{l}8.2 \text { Family support and encourage- } \\
\text { ment to initiate and sustain PA. }\end{array}$} & \\
\hline $\begin{array}{l}\text { Khalil et al. } \\
\text { (2016) }\end{array}$ & $\begin{array}{l}\text { Family support: and commitment } \\
\text { was perceived as an important ele- } \\
\text { ment for some participants to initi- } \\
\text { ate and maintain an exercise } \\
\text { program. [U] }\end{array}$ & $\begin{array}{l}\text { "Family has always been a source } \\
\text { of support for me to accept the } \\
\text { disease and to deal with it. A lot of } \\
\text { mornings I would be very tired } \\
\text { sitting on my sofa or lying in my } \\
\text { bed until my son comes and asks } \\
\text { me to go for a walk with him. His } \\
\text { encouragement pulls me up and it's } \\
\text { just about the start that is difficult } \\
\text { then I get clicked on; I usually feel } \\
\text { much better afterwards." P9 pg } \\
515 \text { [U] }\end{array}$ & & \\
\hline $\begin{array}{l}\text { Ravenek } \\
\text { et al. (2009) }\end{array}$ & $\begin{array}{l}\text { Sources of support: Family mem- } \\
\text { bers - the most salient forms of } \\
\text { support provided by participants' } \\
\text { families were instrumental and } \\
\text { emotional support. [U] }\end{array}$ & $\begin{array}{l}\text { "They encourage me, goad me, } \\
\text { embarrass me into doing some } \\
\text { [activities] and they also will alter } \\
\text { their activities to accommodate me } \\
\text { which is very good. [My husband] } \\
\text { just you know, like he always is } \\
\text { trying to get me into doing more. } \\
\text { He probably encourages me and } \\
\text { gets me going more than I would } \\
\text { do myself." Pg } 1929 \text { [U] }\end{array}$ & & \\
\hline $\begin{array}{l}\text { Ravenek } \\
\text { et al. (2009) }\end{array}$ & $\begin{array}{l}\text { Sources of support: Friends - The } \\
\text { main forms of instrumental support } \\
\text { were the provision of transporta- } \\
\text { tion and mutual participation in } \\
\text { physical activity. }[\mathrm{U}]\end{array}$ & $\begin{array}{l}\text { "They'll come out and walk with } \\
\text { me sometimes or friends will come } \\
\text { out and bike with me. .. it's nice to } \\
\text { have friends who are compassion- } \\
\text { ate, and ah understand what you } \\
\text { are going through." Participant pg } \\
1930 \text { [U] }\end{array}$ & \multirow[t]{2}{*}{$\begin{array}{l}\text { 8.3 Support and encouragement from } \\
\text { friends and co-workers. }\end{array}$} & \\
\hline $\begin{array}{l}\text { Ravenek } \\
\text { et al. (2009) }\end{array}$ & $\begin{array}{l}\text { Sources of support: People in the } \\
\text { workplace - This type of support } \\
\text { commonly took the form of orga- } \\
\text { nising work schedules to allow for } \\
\text { time to participate in specific exer- } \\
\text { cise programs. [U] }\end{array}$ & $\begin{array}{l}\text { "They were all very supportive } \\
\text { because I started [exercising at the } \\
\text { research centre] when I was still } \\
\text { working. So, they all made sure, no } \\
\text { matter who was working with me } \\
\text { that I got off in time." P pg } 1930 \\
\text { [U] }\end{array}$ & & \\
\hline
\end{tabular}

$U$, unequivocal finding; $C$, credible finding; PD, Parkinson's disease; PA, physical activity. 
progressive and fluctuating nature of the disease that was often further complicated by medication cycles. Despite these challenges, pwPD identified personal coping strategies to allow them to undertake functional tasks and engage in PA. This review identified a number of contributory factors that influenced pwPD's ability to participate in PA. These factors can be categorized into intrapersonal characteristics such as: self-efficacy, beliefs and motivation to undertake PA, program design, setting, choice of activities, which were supervised by a knowledgeable instructor who could offer support in terms of monitoring, supervising, educating, and prescribing and progressing individually tailored programs. Participants wished to take part in a program that they found enjoyable, and groups were viewed positively where they were inclusive of people of various PA levels and where people perceived connections between themselves and other participants (for instance similarities in age or disease severity). Group cohesiveness also contributed to a sense of belonging and a social connection, which was important for sharing information and experiences, and which aided engagement. Regular participation in the activity gave pwPD a sense of achievement, which improved their wellbeing. Environmental factors including the accessibility of PA programs in terms of locality and public transport routes, and external support from family, friends and coworkers were also significant contributory factors for participation.

\section{Discussion of findings in relation to contemporary literature}

These qualitative findings provided an insight into the views and experiences of pwPD, and complemented available quantitative evidence of effectiveness to support the development of complex interventions to improve health. ${ }^{62}$ Physical activity behavior is a multifaceted construct and has proven challenging to promote in older people ${ }^{63,64}$ those with long-term conditions ${ }^{65-67}$ and those with $\mathrm{PD},{ }^{9,11,68}$ despite the fact that there is a wealth of quantitative evidence that identifies the benefits of PA in pwPD. ${ }^{13-17}$ There are likely a number of contributory factors which influence participation, and this review provided a comprehensive qualitative overview of the experiences and preferences of those people with PD who do engage in PA.

The personal characteristics associated with ongoing engagement highlighted in our review have resonance with those described within self-efficacy literature. Bandura defines self-efficacy as the "belief in the ability to exercise control over one's health habits". ${ }^{69(p .144)}$ Individuals with high self-efficacy expect more favorable physical, social and self-evaluative outcomes, view impediments as more manageable, and set higher goals for themselves. ${ }^{69}$ The findings of this review would suggest that pwPD who engage in PA demonstrate high personal self-efficacy in overcoming barriers to participation with the use of individualized coping strategies. In accordance with this review, self-efficacy has shown to be a determinate of PA behavior in pwPD. ${ }^{70}$

However, a problem with the utilization of behavioral change theories for pwPD, such as Bandura's social cognitive theory, is that the development of coping strategies to overcome impediments and/or barriers to PA is likely to require a significant amount of reasoning and cognitive capacity that those participants with deteriorated cognitive function may not be able to initiate., ${ }^{4,71}$

A further finding from this review was that pwPD's motivation to undertake PA was dependent on whether the activity met their goals and whether there was a sufficient level of challenge in the activity, and this was reflected in the variety of PA undertaken by pwPD. The important role of motivation in influencing behavior is outlined by the theory of self-determination. ${ }^{72}$ The self-determination theory focuses on the processes through which a person acquires the motivation for initiating new health related behaviors and maintaining them over time. The theory assumes that individuals by nature are active and self-motivated but that they can also be alienated or disaffected by unfavorable social contexts. The balance between their inherent active nature and the social environment can either support or impede that nature. ${ }^{73}$ Human behavior is based on the desire for autonomy, in terms of personal endorsement, competence, the need to feel challenged but capable of achieving goals, and relatedness reflects the degree to which an individual feels connected to and understood by others. ${ }^{72}$

Participation in PA is a multifaceted construct, and the findings from this review identified the role of the affective domain as a contributory factor for participation. People with Parkinson's disease expressed a preference for an activity that was both fun and enjoyable. The affective domain is posited as an alternative model for enhancing motivation and 
adherence in PA. ${ }^{74,75}$ For example, intrinsic regulation (behavioral engagement for reasons of pleasure) and affective attitude (expectations of enjoyment, fun, pleasure) have shown positive effects on PA in older adults. ${ }^{75}$ Enjoying an activity and feeling good about participating may re-enforce that behavior, which is an important aspect for sustained engagement. Previous positive experiences of PA enhanced pwPD's views of engagement in PA. ${ }^{76}$ Anticipation that PA will not be enjoyable and/or will be unpleasant may explain why some pwPD are sedentary.

This review provided evidence that support from peers, family and friends, and, in particular, the instructor were important factors in aiding motivation to attend PA programs. Support was provided in terms of instrumental (e.g. providing transport and mutual participation), emotional (e.g. providing encouragement), and informational (e.g. education about exercise). ${ }^{30}$ Furthermore, accessibility in terms of public transport, cost and access were contributing factors influencing engagement and sustained participation. These findings are in agreement with research in older people ${ }^{64}$ and people with disabilities and/or long-term conditions. ${ }^{65,67,77,78}$
This review suggests that a range of factors including disease presentation, intrapersonal characteristics, program design, social and physical environment, and external support all contribute to sustained engagement in PA in pwPD. As PA in pwPD is affected by diverse factors, the integration of ideas from several behavioral theories and models has been incorporated into a proposed ecological model of sustained engagement in PA. This model takes in account the different contributory factors and importance of the relationship between individuals and their social and physical environment. ${ }^{73,79}$ (see Figure 2). This review was not able to determine the relative importance of these factors, or combination of factors, that contribute the most to pwPD's ability to participate in PA. This picture was further complicated by the individualized and fluctuating nature of the disease presentation and the impact of on/off symptoms due to medication cycles, which need to be considered by pwPD who are planning PA. Therefore, it is likely that these factors are not static but fluctuate on a day-to-day basis adding to the complexity of engagement and sustained participation.

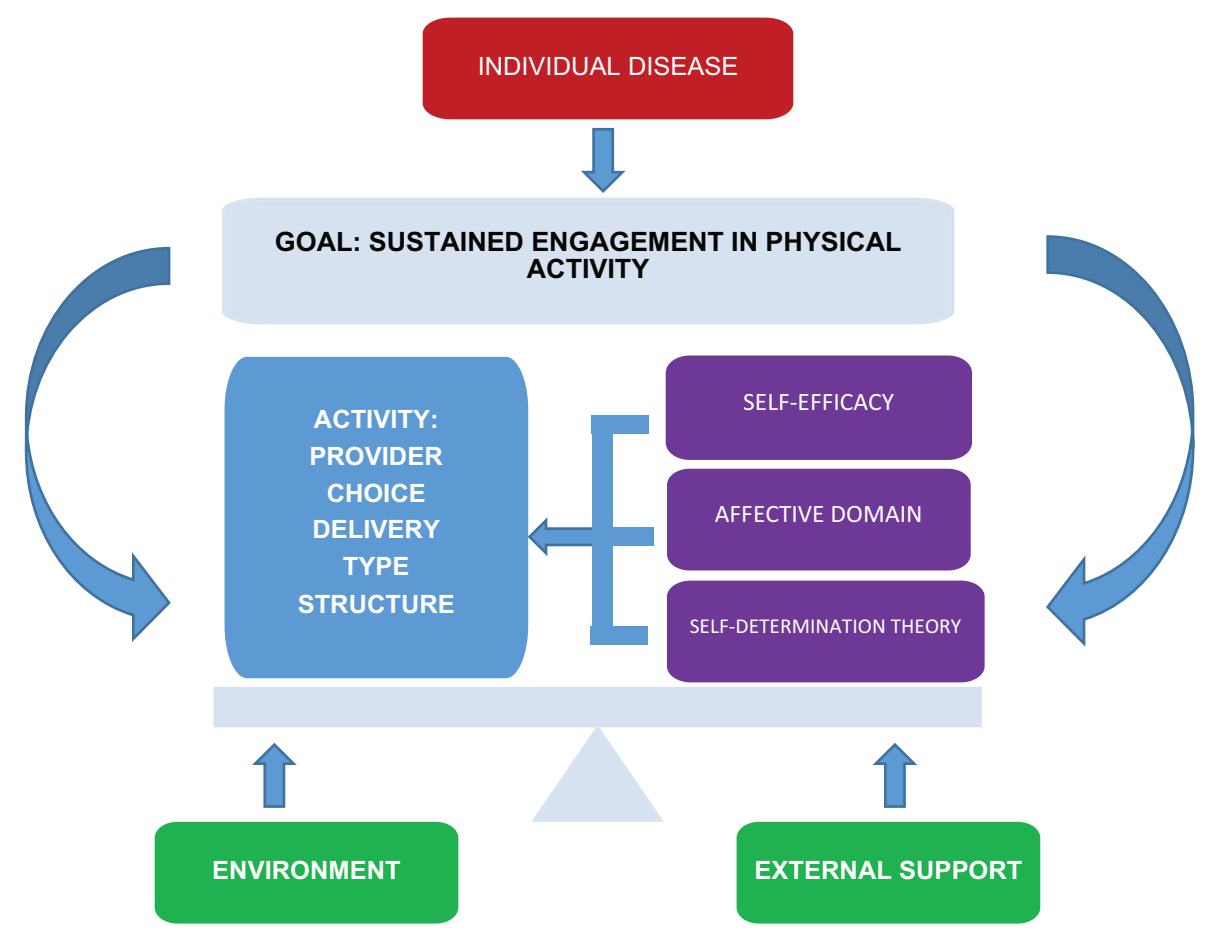

Figure 2: Proposed ecological model of people with Parkinson's disease engagement in physical activity 


\section{Limitations of the review}

A limitation of this review is that we did not find any studies that described pwPD's views and experiences of specific behavior change interventions. It may be that instructors were encouraging behavior change implicitly within the program but that this was not necessarily perceived by pwPD as a strategy. Regardless, the fact that it was not mentioned suggests that it was not prioritized as important by participants.

The studies comprising this review were confined to western countries, with the exception of two studies which were undertaken in Jordan and provided information on the cultural challenges of PA in older people in an Arabic country. None of the included studies identified the cultural make-up of participants, which means the impact of culture and ethnicity on PA in pwPD could not be fully explored.

The research evidence with regard to pwPD's experiences and, preferences, and the motivators and barriers to PA, as well as strategies designed to enhance participation, was limited by the small number of included studies and small participant numbers. Furthermore, the ConQual assessment for the findings was low. Therefore, any recommendations arising from the review were also lowered in their applicability.

Importantly, this review did not address the views and experiences of pwPD who were inactive, or who had discontinued their engagement in PA, as all studies involved pwPD who were active. Therefore, the synthesized findings were limited to pwPD who undertook PA, rather than those who did not engage. Given that those who did not choose to engage were the individuals who may have needed the most support to do so, this was a significant limitation in the existing evidence base.

\section{Conclusion}

People with PD perceive engagement in PA as a positive experience, which aids with managing their symptoms and enhancing their wellbeing and quality of life. This review has identified a number of contributory factors, which influence pwPD's ability to sustain engagement in PA: disease presentation, intrapersonal characteristics, program design, external support, and the social and physical environment. The contribution and weighting of these factors will affect an individual's engagement and sustained participation in PA.

\section{Recommendations for practice}

The recommendations for practice are graded according to the JBI Grades of Recommendations, ${ }^{80}$ People with Parkinson's disease value the following aspects as important in sustaining their engagement in PA:

i) A choice of PA programs that are meaningful and that meet their needs. Group programs that are inclusive of abilities, but also challenging are viewed positively. The incorporation of individually tailored goals would allow participants to evaluate their progress and should be related to their functional activities. (Grade B)

ii) The PA program should be overseen by an instructor who is knowledgeable about Parkinson's disease. (Grade B)

iii) Programs that are enjoyable include those with a positive and inclusive social environment and the use of music. (Grade B)

\section{Recommendations for policy}

i) The involvement of pwPD in the design and commissioning of PA programs to ensure that their needs are understood and met. (Grade B)

ii) People with Parkinson's disease value PA irrespective of provider, and therefore policy makers should collaborate with the third sector to encourage the delivery of PA programs. Referrals and signposting to local groups should reflect this in order to offer choice and increase accessibility locally. (Grade B)

iii) Policy makers should recognize the importance of supporting PA through the provision of resources, such as education materials. (Grade B)

\section{Recommendations for research}

i) Authors should provide full information with regards to the methodology and philosophical underpinnings of the research in accordance with the Consolidated Criteria for Reporting Qualitative Research (COREQ) guidelines. ${ }^{81}$

ii) Research should be carried out to explore the perspectives of pwPD who are inactive with the aim of exploring the similarities and differences between them and those who engage, with the intention of developing the proposed model further.

iii) Research should be carried out with instructors to explore current practice, readiness and 
ability to support pwPD to engage in PA with the aim of exploring what behavior change interventions they utilize within programs and their views on their success in engaging pwPD in PA.

\section{References}

1. Munn Z, Porritt K, Lockwood C, Aromataris E, Pearson A. Establishing confidence in the output of qualitative resarch synthesis:the ConQual approach. BMC Med Res Methodol 2014;14(108):1-7.

2. Elbaz A, Carcaillon L, Kab S, Moisan F. Epidemiology of Parkinson's disease. Revue Neurol (Paris) 2016;172(1):14-26.

3. de Lau LML, Breteler MMB. Epidemiology of Parkinson's disease. Lancet Neurol 2006;5(6):525-35.

4. Bartels AL, Leenders KL. Parkinson's disease: the syndrome, the pathogenesis and pathophysiology. Cortex 2009;45(8): 915-21.

5. Crizzle AM, Newhouse IJ. Themes associated with exercise adherence in persons with Parkinson's disease: A qualitative study. Occup Ther Health Care 2012;26(2-3):174-86.

6. Friedman JH, Brown RG, Comella C, Garber CE, Krupp LB, Lou JS, et al. Fatigue in Parkinson's disease: a review. Mov Disord 2007;22(3):297-308.

7. Sagna A, Gallo JJ, Pontone GM. Systematic review of factors associated with depression and anxiety disorders among older adults with Parkinson's disease. Parkinsonism Relat Disord 2014;20(7):708-15.

8. Shulman LM, Gruber-Baldini AL, Anderson KE, Vaughan CG, Reich SG, Fishman PS, et al. The evolution of disability in Parkinson disease. Mov Disord 2008;23(6):790-6.

9. van Nimwegen $M$, Speelman AD, Hofman-van Rossum EJ, Overeem S, Deeg DJ, Borm GF, et al. Physical inactivity in Parkinson's disease. J Neurol 2011;258(12):2214-21.

10. Fertl E, Doppelbauer A, Auff E. Physical activity and sports in patients suffering from Parkinson's disease in comparison with healthy seniors. J Neural Transm 1993;5(2):157-61.

11. de Carvalo LR, de Araujo L, Cardoso F, Rodrigues-de-Paula F. Main determinants of physical activity levels in individuals with Parkinson's disease. Arq Neuropsiquiatr 2016;74(2): 112-6.

12. Caspersen CJ, Powell KE, Christenson GM. Physical activity, exercise, and physical fitness: definitions and distinctions for health-related research. Public Health Rep 1985;100(2): 126-31.

13. Allen NE, Sherrington C, Paul SS, Canning CG. Balance and falls in Parkinson's disease: a meta-analysis of the effect of exercise and motor training. Mov Disord 2011;26(9):160515.

14. Goodwin VA, Richards SH, Taylor RS, Taylor AH, Campbell JL. The effectiveness of exercise interventions for people with Parkinson's disease: a systematic review and meta-analysis. Mov Disord 2008;23(5):631-40.
15. Saltychev M, Barlund E, Paltamaa J, Katajapuu N, Laimi K. Progressive resistance training in Parkinson's disease: a systematic review and meta-analysis. BMJ Open 2016;6(1):e008756.

16. Shu HF, Yang T, Yu SX, Huang HD, Jiang LL, Gu JW, et al. Aerobic exercise for Parkinson's disease: a systematic review and meta-analysis of randomized controlled trials. PLoS One 2014;9(7):e100503.

17. Tomlinson CL, Patel S, Meek C, Herd CP, Clarke CE, Stowe R, et al. Physiotherapy intervention in Parkinson's disease: systematic review and meta-analysis. BMJ 2012;345:e5004.

18. Uhrbrand A, Stenager E, Pedersen MS, Dalgas U. Parkinson's disease and intensive exercise therapy-a systematic review and meta-analysis of randomized controlled trials. J Neurol Sci 2015;353(1-2):9-19.

19. Allender S, Foster C, Scarborough P, Rayner M. The burden of physical activity-related ill health in the UK. J Epidemiol Community Health 2007;61(4):344-8.

20. Cramp F, Berry J, Gardiner M, Smith F, Stephens D. Health behaviour change interventions for the promotion of physical activity in rheumatoid arthritis: a systematic review. Musculoskeletal Care 2013;11(4):238-47.

21. Witcher CS, McGannon KR, Hernandez P, Dechman G, Ferrier S, Spence JC, et al. A Qualitative Exploration of Exercise Among Pulmonary Rehabilitation Participants: Insight From Multiple Sources 58of Social Influence. Respir Care 2015;60(11):1624-34.

22. Scianni A. Tai Chi improves balance and prevents falls in people with Parkinson's disease. J Physiother 2015;61(1):44.

23. Ni X, Liu S, Lu F, Shi X, Guo X. Efficacy and safety of Tai Chi for Parkinson's disease: a systematic review and meta-analysis of randomized controlled trials. PLoS One 2014;9(6):e99377.

24. Sharp K, Hewitt J. Dance as an intervention for people with Parkinson's disease: a systematic review and meta-analysis. Neurosci Biobehav Rev 2014;47:445-56.

25. Li F, Harmer P, Liu Y, Eckstrom E, Fitzgerald K, Stock R, et al. A randomized controlled trial of patient-reported outcomes with tai chi exercise in Parkinson's disease. Mov Disord 2014;29(4):539-45.

26. McGill A, Houston S, Lee RY. Dance for Parkinson's: a new framework for research on its physical, mental, emotional, and social benefits. Complement Ther Med 2014;22(3):42632.

27. Rocha PA, Slade SC, McClelland J, Morris ME. Dance is more than therapy: Qualitative analysis on therapeutic dancing classes for Parkinson's. Complement Ther Med 2017;34:1-9.

28. Schutzer KA, Graves BS. Barriers and motivations to exercise in older adults. Prev Med 2004;39(5):1056-61.

29. Ellis T, Boudreau JK, DeAngelis T, Brown LE, Cavanaugh JT, Earhart GM, et al. Barriers to exercise in people with Parkinson disease. Phys Ther 2013;93(5):628.

30. Ravenek MJ, Schneider MA. Social support for physical activity and perceptions of control in early Parkinson's disease. Disabil Rehabil 2009;31(23):1925-36. 
31. Abraham C, Kelly MP, West R, Michie S. The UK National Institute for Health and Clinical Excellence public health guidance on behaviour change: a brief introduction. Psychol Health Med 2009;14(1):1-8.

32. NICE. Behaviour change: general approaches United Kingdom: Public Health Guideline; 2007.

33. Sangelaji B, Smith CM, Paul L, Sampath KK, Treharne GJ, Hale $L A$. The effectiveness of behaviour change interventions to increase physical activity participation in people with multiple sclerosis: a systematic review and meta-analysis. Clin Rehabil 2016;30(6):559-76.

34. Jordan JL, Holden MA, Mason EE, Foster NE. Interventions to improve adherence to exercise for chronic musculoskeletal pain in adults. Cochrane Database Syst Rev 2010;1:CD005956.

35. Speelman $A D$, van de Warrenburg $B P$, van Nimwegen $M$, Petzinger G, Munneke M, Bloem BR. How might physical activity benefit patients with Parkinsons Disease. Nat Rev Neurol 2011;7(9):528-34.

36. Speelman AD, van Nimwegen $M$, Bloem BR, Munneke $M$. Evaluation of implementation of the ParkFit program: $A$ multifaceted intervention aimed to promote physical activity in patients with Parkinson's disease. Physiother 2014;100(2):134-41.

37. van der Kolk NM, van Nimwegen M, Speelman AD, Munneke $\mathrm{M}$, Backx FJ, Donders $\mathrm{R}$, et al. A personalized coaching program increases outdoor activities and physical fitness in sedentary Parkinson patients: a post-hoc analysis of the ParkFit trial. Parkinsonism Relat Disord 2014;20(12):1442-4.

38. Ellis T, Latham NK, DeAngelis TR, Thomas CA, Saint-Hilaire M, Bickmore TW. Feasibility of a virtual exercise coach to promote walking in community-dwelling persons with Parkinson disease. Am J Phys Med Rehabil 2013;92(6):472-81.

39. Hunter H, Lovegrove C, Haas B, Freeman J, Gunn H. Experiences of people with Parkinson's disease and their views of physical activity interventions: a qualitative systematic review protocol. JBI Database System Rev Implement Rep 2017;15(11):2619-23.

40. Aromataris E, Munn Z (Editors). Joanna Briggs Institute Reviewer's Manual [Internet]. 2017. Adelaide: Joanna Briggs Institute; 2017. Available from: https://reviewersmanual. joannabriggs.org/.

41. Ramaswamy B. Action research with people with Parkinson's: A physiotherapist's role in supporting self-management and wellness. Physiother 2015;101(Supplement 1): e1254.

42. Elsworth C, Dawes H, Sackley C, Soundy A, Howells K, Wade $D$, et al. A study of perceived facilitators to physical activity in neurological conditions. Int J Ther Rehabil 2009;16(1): 17-23.

43. Moher D, Liberati A, Tetziaff J, Altman DS, the PRISMA Group. Preferred reporting items for systematic review and meta-analyses: the PRISMA Statement. PLoS Med 2009; 6(7):e1000097.
44. Eriksson B-M, Arne M, Ahlgren C. Keep moving to retain the healthy self: the meaning of physical exercise in individuals with Parkinson's disease. Disabil Rehabil 2013;35(26):223744.

45. O'Brien C, Clemson L, Canning CG. Multiple factors, including non-motor impairments, influence decision making with regard to exercise participation in Parkinson's disease: a qualitative enquiry. Disabil Rehabil 2016;38(5):472-81.

46. O'Brien M, Dodd KJ, Bilney B. A qualitative analysis of a progressive resistance exercise programme for people with Parkinson's disease. Disabil Rehabil 2008;30(18):1350-7.

47. Houston S, McGill A, Lee R, Watkins K, Donald C. English National Ballet Dance for Parkinsons. An Investigative Study 2. A report on a three year mixed methods-research-study. Research Report 2015:1-48.

48. Hammarlund CS, Andersson $\mathrm{K}$, Andersson M, Nilsson $\mathrm{MH}_{\text {, }}$ Hagell $P$. The significance of walking from the perspective of people with Parkinson's disease. J Parkinsons Dis 2014;4(4):657-63.

49. Sheehy T. The Parkinson's experience of group physical activity- Understanding social support, social comparison, physical self-percptions, and posttraumatice growth. Open Acess Theses 2014;680:1-87.

50. Jones $D$, Rochester $L$, Birleson $A$, Hetherington $V$, Nieuwboer A, Willems A, et al. Everyday walking with Parkinson's disease: understanding personal challenges and strategies. Disabil Rehabil 2008;30(16):1213-21.

51. Pretzer-Aboff I, Galik E, Resnick B. Parkinson's disease: barriers and facilitators to optimizing function. Rehabil Nurs 2009;34(2):55-83.

52. Bassett S, Stewart J, Giddings L. Nordic walking versus ordinary walking for people with Parkinson's disease: A single case design. N Z J Physiother 2012;40(3):117-22.

53. Hislop J, Gray S, Melling S, Paraskevopoulos L, Baer G. An exploration of physical activity experiences in people with Parkinson's disease. Physiother 2015;101(Supplement 1):e572-3.

54. Kunkel D, Robison J, Fitton C, Hulbert S, Roberts L, Wiles R, et al. It takes two: the influence of dance partners on the perceived enjoyment and benefits during participation in partnered ballroom dance classes for people with Parkinson's. Disabil Rehabil 2017;40(16):1-10.

55. Westheimer O, McRae C, Henchcliffe C, Fesharaki A, Glazman $\mathrm{S}$, Ene $\mathrm{H}$, et al. Dance for PD: a preliminary investigation of effects on motor function and quality of life among persons with Parkinson's disease (PD). J Neural Transm 2015;122(9):1263-70.

56. Quinn L, Busse M, Khalil H, Richardson S, Rosser A, Morris H. Client and therapist views on exercise programmes for early-mid stage Parkinson's disease and Huntington's disease. Disabil Rehabil 2010;32(11):917-28.

57. Khalil H, Nazzal M, Al-Sheyab N. Parkinson's disease in Jordan: Barriers and motivators to exercise. Physiother 2016;32(7):509-19. 
58. Davis J, Ebrbart A, Trzcinski BH, Kille S, Mount J. Variablity of experiences for individuals living with Parkinson disease. Neurol Report 2003;27(2):38-45.

59. Bognar S, DeFaria AM, O'Dwyer C, Pankiw E, Bogler JS, Teixeira $S$, et al. More than just dancing: experiences of people with Parkinson's disease in a therapeutic dance program. Disabil rehabil 2017;39(11):1073-8.

60. Zhao YJ, Wee HL, Chan YH, Seah SH, Au WL, Lau PN, et al. Progression of Parkinson's disease as evaluated by Hoehn and Yahr stage transition times. Mov Disord 2010;25(6): 710-6.

61. Khalil H, Busse M, Quinn L, Nazzal M, Batyha W, Alkhazaleh S, et al. A pilot study of a minimally supervised homquinne exercise and walking program for people with Parkinson's disease in Jordan. Neurodegener Dis Manag 2017;7(1):7384.

62. Craig P, Dieppe P, Macintyre S, Michie S, Nazareth I, Petticrew M. Developing and evaluating complex interventions: new guidance. Med Res Counc 2006. Available from: https:// researchonline.Ishtm.ac.uk/5902/1/Research_Methods_and_Reporting.full.pdf.

63. Devereux-Fitzgerald A, Powell R, Dewhurst A, French DP. The acceptability of physical activity interventions to older adults: A systematic review and meta-synthesis. Soc Sci Med 2016;158:14-23.

64. Franco MR, Tong A, Howard K, Sherrington C, Ferreira PH, Pinto RZ, et al. Older people's perspectives on participation in physical activity: a systematic review and thematic synthesis of qualitative literature. $\mathrm{Br} J$ Sports Med 2015;49(19):1268-76.

65. Casey D, de Civta M, Dasgupta K. Understanding physical activity facilitators and barriers during and following $a$ supervised exercise programme in Type 2 diabetes: a qualitative study. Diabet Med 2010;27(1):79-84.

66. Hendry M, Williams NH, Markland D, Wilkinson C, Maddison P. Why should we exercise when our knees hurt? A qualitative study of primary care patients with osteoarthritis of the knee. Fam Pract 2006;23(5):558-67.

67. Junker L, Carlberg EB. Factors that affect exercise participation among people with physical disabilities. Adv in Physiother 2011;13(1):18-25.

68. Ellis TE, Boudreau JK, DeAngelis TR, Brown LE, Cavanaugh JT, Earhart GE, Ford MP, Foreman B, Dibble LE. Barriers to Exercsie in People with Parkinsons Disease. Phys Ther 2013;93(5):628-36.

69. Bandura A. Health promotion by social cognitive means. Health Educ Behav 2004;31(2):143-64.
70. Ellis T, Cavanaugh JT, Gammon ME, Ford MP, Foreman KB, Fredman L, Boudreau JK, Dibble LE. Factors Associated with Exercise Behavior in People with Parkinson's Disease. Phys Ther 2011;91(12):1838-48.

71. Robbins TW, Cools R. Cognitive deficits in Parkinson's disease: a cognitive neuroscience perspective. Mov Disord 2014;29(5):597-607.

72. Ryan R, Patrick H, Deci El, Williams GC. Facilitating health behaviour change and its maintenance: Interventions based on Self-Determination Theory. Eur Health Psychol 2008;10:2-5.

73. Buchan DS, Ollis S, Thomas NE, Baker JS. Physical activity behaviour: an overview of current and emergent theoretical practices. J Obes 2012;2012(ID546459):1-11.

74. Ekkekakis P, Hargreaves EA, Parfitt G. Invited Guest Editorial: Envisioning the next fifty years of research on the exerciseaffect relationship. Psychol Sport and Exerc 2013;14(5): $751-8$.

75. Rhodes RE, Kates A. Can the affective response to exercise predict future motives and physical activity behavior? A systematic review of published evidence. Ann Behav Med 2015;49:715-31.

76. Dunton GF, Vaughan E. Anticipated affective consequences of physical activity adoption and maintenance. Health Psychol 2008;27(6):703-10.

77. Pentecost C, Taket A. Understanding exercise uptake and adherence for people with chronic conditions: a new model demonstrating the importance of exercise identity, benefits of attending and support. Health Educ Res 2011;26(5): 908-22.

78. Slade SC, Molloy E, Keating JL. People with non-specific chronic low back pain who have participated in exercise programs have preferences about exercise: a qualitative study. Aus J Physiother 2009;55(2):115-21.

79. Bauman AE, Reis RS, Sallis JF, Wells JC, Loos RJF, Martin BW. Correlates of physical activity: why are some people physically active and others not? The Lancet 2012;380(9838): 258-71.

80. Joanna Briggs Institute Levels of Evidence and Grades of Recommendation Working Party. New JBI Grades of Recommendation. Joanna Briggs Institute. 2013. Available at: http://joannabriggs.org/assets/docs/approach/JBI-gradesof-recommendation_2014.pdf.

81. Tong A, Sainsbury P, Craig J. Consolidate criteria for reporting qualitative research (COREQ): a 32-item checklist for interviews and focus groups. Int J Qual Health Care 2007;19(6):349-57. 
Appendix I: Dependability scores for included studies

\begin{tabular}{|c|c|c|c|c|c|c|}
\hline \multicolumn{7}{|c|}{ Dependability score } \\
\hline Citation & $\begin{array}{l}\text { Is there congruity } \\
\text { between the } \\
\text { research } \\
\text { methodology and } \\
\text { the research } \\
\text { question or } \\
\text { objectives }\end{array}$ & $\begin{array}{l}\text { Is there congruity } \\
\text { between the } \\
\text { research } \\
\text { methodology } \\
\text { and the methods } \\
\text { used to collect } \\
\text { data? }\end{array}$ & $\begin{array}{l}\text { Is there congruity } \\
\text { between the } \\
\text { research } \\
\text { methodology and } \\
\text { the representation } \\
\text { and analysis of } \\
\text { data? }\end{array}$ & $\begin{array}{l}\text { Is there a } \\
\text { statement locating } \\
\text { the researcher } \\
\text { culturally or } \\
\text { theoretically? }\end{array}$ & $\begin{array}{l}\text { Is the influence } \\
\text { of the researcher } \\
\text { on the research, } \\
\text { and vice-versa, } \\
\text { addressed? }\end{array}$ & $\begin{array}{l}\text { Dependability } \\
\text { score }\end{array}$ \\
\hline $\begin{array}{l}\text { Bassett, et al. } \\
(2012)^{52}\end{array}$ & Yes & Yes & Yes & No & No & $3 / 5 \mathrm{Mod}$ \\
\hline $\begin{array}{l}\text { Bognar, et al. } \\
(2017)^{59}\end{array}$ & Yes & Yes & Yes & No & No & 3/5 Mod \\
\hline $\begin{array}{l}\text { Crizzle, et al. } \\
(2012)^{5}\end{array}$ & Yes & Yes & Yes & No & Yes & 4/5 High \\
\hline $\begin{array}{l}\text { Davis, et al. } \\
(2003)^{58}\end{array}$ & Yes & Yes & Yes & No & No & 3/5 Mod \\
\hline $\begin{array}{l}\text { Erikson, et al. } \\
(2013)^{44}\end{array}$ & Yes & Yes & Yes & Yes & Yes & 5/5 High \\
\hline $\begin{array}{l}\text { Hammarlund, et al. } \\
(2014)^{48}\end{array}$ & Yes & Yes & Yes & No & Yes & 4/5 High \\
\hline $\begin{array}{l}\text { Hislop, et al. } \\
(2015)^{53}\end{array}$ & Yes & Yes & Unclear & No & No & 2/5 Mod \\
\hline $\begin{array}{l}\text { Houston, et al. } \\
(2015)^{47}\end{array}$ & No & Yes & Unclear & No & No & 1/5 Low \\
\hline $\begin{array}{l}\text { Jones, et al. } \\
(2008)^{50}\end{array}$ & Yes & Yes & Yes & Yes & Yes & 5/5 High \\
\hline $\begin{array}{l}\text { Khalil, et al. } \\
(2017)^{61}\end{array}$ & Yes & Yes & Yes & No & No & 3/5 Mod \\
\hline $\begin{array}{l}\text { Khalil, et al. } \\
(2016)^{57}\end{array}$ & Yes & Yes & Yes & No & No & 3/5 Mod \\
\hline $\begin{array}{l}\text { Kunkel, et al. } \\
(2017)^{54}\end{array}$ & Yes & Yes & Yes & Yes & No & 4/5 High \\
\hline $\begin{array}{l}\text { O'Brien, et al. } \\
(2016)^{45}\end{array}$ & Yes & Yes & Yes & No & Yes & 4/5 High \\
\hline $\begin{array}{l}\text { O'Brien et al. } \\
(2008)^{46}\end{array}$ & Yes & Yes & Yes & Yes & No & 4/5 High \\
\hline $\begin{array}{l}\text { Pretzer-Aboff, et al. } \\
(2009)^{51}\end{array}$ & Yes & Yes & Yes & No & No & 3/5 Mod \\
\hline $\begin{array}{l}\text { Quinn, et al. } \\
(2010)^{56}\end{array}$ & Yes & Yes & Yes & No & No & 3/5 Mod \\
\hline $\begin{array}{l}\text { Ravenek, et al. } \\
(2009)^{30} \text {, }\end{array}$ & Yes & Yes & Yes & No & No & 3/5 Mod \\
\hline Sheehy $(2014)^{49}$ & Yes & Yes & Yes & Yes & No & 4/5 High \\
\hline $\begin{array}{l}\text { Westheimer, et al. } \\
(2015)^{55}\end{array}$ & Yes & Yes & Yes & No & No & 3/5 Mod \\
\hline
\end{tabular}




\section{Appendix II: Calculation of ConQual score}

Synthesized finding 1: Participating in physical activity is seen as positive, participants report improvements in physical and psychological function and symptom control. Participating in physical activity leads to holistic changes, including a sense of achievement, improved confidence and wellbeing.

\begin{tabular}{|c|c|c|}
\hline $\begin{array}{l}\text { Dependability } \\
\text { Crizzle et al. (2012) (H) } \\
\text { Hammarlund et al. (2014) (H) } \\
\text { O'Brien et al. (2008) (H) } \\
\text { Sheehey (2014) (H) } \\
\text { Bassett et al. (2012) (M) } \\
\text { Bognar et al. (2016) (M) } \\
\text { Westheimer et al. (2015) (M) } \\
\text { Houston et al. (2015) (L) } \\
\text { Dependability is moderate: } \\
\text { downgraded } 1 \text { level due to a } \\
\text { mixture of dependability among } \\
\text { findings (4 high, } 3 \text { moderate, } \\
1 \text { low) }\end{array}$ & $\begin{array}{l}\text { Credibility } \\
13 \text { findings, } 2 \text { categories } \\
12 \text { Unequivocal } \\
1 \text { Credible } \\
\text { Credibility of findings is moderate: } \\
\text { downgraded } 1 \text { level due to a mixture } \\
\text { of unequivocal and credible findings }\end{array}$ & $\begin{array}{l}\text { ConQual score } \\
\text { Confidence in the findings is low: } \\
\text { downgraded } 2 \text { levels due to moder- } \\
\text { ate dependability and moderate } \\
\text { credibility }\end{array}$ \\
\hline
\end{tabular}

Synthesized finding 2: Parkinson's disease is perceived to impact on all aspects of physical activity with temporal fluctuation in symptoms presenting both emotional and physical challenges. Changes to the level and type of physical activity and individual strategies are used to maximize participation.

\begin{tabular}{l|l}
$\begin{array}{l}\text { Dependability } \\
\text { Hammarlund } \text { et al. (2014) (H) }\end{array}$ & $\begin{array}{l}\text { Credibility } \\
\text { 20 findings, 2 categories } \\
\text { Jones } \text { et al. }(2008)(\mathrm{H})\end{array}$ \\
$\begin{array}{l}\text { Kunkel } \text { et al. }(2017)(\mathrm{H}) \\
\text { O'Brien } \text { et al. }(2016)(\mathrm{H})\end{array}$ & $\begin{array}{l}\text { Credible } \\
\text { Davis } \text { et al. }(2003)(\mathrm{M})\end{array}$ \\
$\begin{array}{l}\text { Pretzer Aboff } \text { et al. (2009) (M) } \\
\text { Houston } \text { et al. } \text { (2015) (L) }\end{array}$ & $\begin{array}{l}\text { Credibility of findings is moderate: } \\
\text { downgraded 1 level due to a mixture } \\
\text { of unequivocal and credible }\end{array}$ \\
$\begin{array}{l}\text { Dependability is moderate: } \\
\text { downgraded 1 level due to a } \\
\text { mixture of dependability } \\
\text { (4 high, } 2 \text { moderate, 1 low) }\end{array}$ & \\
\hline
\end{tabular}

\section{ConQual score}

Confidence in the findings is low: downgraded 2 levels due to moderate dependability and moderate credibility

Synthesized finding 3: Participation in physical activity is highly individual, with participants valuing activities, which are perceived as personally relevant, and tailored to their needs and preferences. Participant perceptions of physical activity are affected by expectations and self-evaluation of progress.

\section{Dependability}

Erickson et al. (2013) (H)

O'Brien et al. (2008) (H)

O'Brien et al. (2016) (H)

Davis et al. (2003) (M)

Khalil et al. (2016) (M)

Pretzer Aboff et al. (2009) (M)

Quinn et al. (2010) (M)

Houston et al. (2015) (L)

Dependability is moderate: downgraded 1 level due to a mixture of dependability ( 3 high, 4 moderate, 2 low)

\section{Credibility}

9 findings, 2 categories

5 Unequivocal

4 Credible

Credibility of findings is moderate: downgraded 1 level due to a mixture of unequivocal and credible

\section{ConQual score}

Confidence in the findings is low: downgraded 2 levels due to moderate dependability and moderate credibility 
Synthesized finding 4: External factors can affect participants' experience of physical activity. Involvement of family members/friends and use of music make sessions enjoyable and increase wellbeing. Support from instructors to ensure physical activity programs are structured and simple to undertake, to explain the relevance of activities and to support progression gives participants confidence and enhances their participation.

\section{Dependability}

Crizzle et al. (2012) (H)

Kunkel et al. (2017) (H)

Bassett et al. (2012) (M)

Kahlil et al. (2017) (M)

Pretzer Aboff et al. (2009) (M)

Ravenek et al. (2009) (M)

Houston et al. (2015) (L)

Quinn et al. (2010) (L)

Dependability is moderate: downgraded 1 level due to a mixture of dependability ( 2 high, 4 moderate, 2 low)

Synthesized finding 5: A personal desire to maintain independence and a belief that physical activity can slow deterioration are driving forces for participation. Motivation is enhanced by perceived improvement in symptoms and feelings of accountability to oneself or others.

\section{Dependability}

Erikson et al. (2013) (H)

O'Brien et al. (2016) (H)

Bassett et al. (2012) (M)

Bognar et al. (2016) (M)

Khalil et al. (2017) (M)

Quinn et al. (2010) (M)

Ravenek et al. (2009) (M)

Dependability is moderate: downgraded 1 level due to a mixture of dependability ( 2 high, 5 moderate)

\section{Credibility \\ 11 findings, 3 categories \\ 8 Unequivocal \\ 3 Credible}

Credibility of findings is low: downgraded 1 level due to a mixture of unequivocal and credible.

\section{ConQual score}

Confidence in the findings is low: downgraded 2 levels due to moderate dependability and moderate credibility.

Synthesized finding 6: Participants report that personal characteristics such as exercise habit, information seeking, resilience, problem solving and interest in the activity are motivators for engagement. However, lack of time, low outcome expectations and cultural challenges are seen as barriers. Comparisons with others can be a motivator or barrier to engagement.

\section{Dependability}

Erikson et al. (2013) (H)

Kunkel et al. (2017) (H)

O’Brien et al. (2016) (H)

Sheehy (2014) (H)

Bognar et al. (2016) (M)

Davis et al. (2003) (M)

Khalil et al. (2017) (M)

Ravenek et al. (2009) (M)

Houston et al. (2015) (L)

Dependability is moderate: downgraded 1 level due to a mixture of dependability (4 high, 4 moderate, 1 low)

\section{Credibility}

12 findings, 3 categories

7 Unequivocal

5 Credible

Credibility of findings is low: downgraded 1 level due to a mixture of unequivocal and credible.

\section{ConQual score}

Confidence in the findings is low: downgraded 2 levels due to moderate dependability and moderate credibility. 
Synthesized finding 7: Difficulty obtaining an initial diagnosis, accessibility of services, disease symptoms (both physical and psychological) and severity all impact the ability and desire to undertake physical activity in people with Parkinson's disease.

\section{Dependability}

O'Brien et al. (2016) (H)

Sheehy (2014) (H)

Davis et al. (2003) (M)

Khalil et al. (2016) (M)

Khalil et al. (2017) (M)

Pretzer Aboff et al. (2009) (M)

Quinn et al. (2010) (M)

Ravenek et al. (2009) (M)

Dependability is moderate: downgraded 1 level due to a mixture of dependability ( 2 high, 6 moderate)

Synthesized finding 8: Participants report that group members, family, friends and co-workers provide support for them to initiate and sustain physical activity

\section{Dependability}

Crizzle et al. (2012) (H)

O’Brien et al. (2008) (H)

O’Brien et al. (2016) (H)

Sheehy (2014) (H)

Bognar et al. (2016) (M)

Hislop et al. (2015) (M)

Khalil et al. (2016) (M)

Kahlil et al. (2017) (M)

Ravenek et al. (2009) (M)

Houston et al. (2016) (L)

Dependability is moderate: downgraded 1 level due to a mixture of dependability (4 high, 5 moderate, 1 low).

\section{Credibility}

15 findings, 2 categories

14 Unequivocal

1 Credible

Credibility of findings is moderate: downgraded 1 level due to a mixture of unequivocal and credible.

\section{ConQual score}

Confidence in the findings is low: downgraded 2 levels due to moderate dependability and moderate credibility.
Credibility

13 findings, 3 categories

10 Unequivocal

3 Credible

Credibility of findings is moderate: downgraded 1 level due to a mixture of mainly unequivocal and credible.

\section{ConQual score}

Confidence in the findings is low: downgraded 2 levels due to moderate dependability and moderate credibility. 


\section{Appendix III: Search strategies}

MEDLINE and Embase via OVID: conducted 29 June 2017

Search term

\#1 Parkinson*,ti,ab,kw. Or Parkinson's disease/or exp Parkinson Disease/or Parkinson*.mp. or exp Aged/or pd.ti,ab,kw. Or exp Aged/or exp Parkinson Disease/or pd*.mp

\#2 Physical activity,ti.ab.kw. or physical activity/or exercise.ti,ab,kw. or exercise/or motor activity.ti,ab,kw. or physical fitness*.ti,ab,kw. or leisure activity.ti,ab,kw. or walk*.ti,ab,kw. or tai chi.ti,ab,kw. or qigong.ti,ab,kw. or swim* .ti,ab,kw. or yoga.ti,ab,kw.

\#3 Experience*.ti,ab,kw. or preference*ti,ab,kw. or view*ti,ab,kw. or exp Atttitude to Health/or exp Attitude/ore exp Health Knowledge, attitudes, Practice/or view*.mp or exp Choice Behabior/or preference*.mp. or exp Decision making/or participation.ti,ab,kw. or engagement.ti,ab,kw. or adherence.ti,ab,kw. or compliance.ti,abkw. Or concordance.ti,ab,kw. or enablers.ti,ab,kw. or motivators.ti,ab,kw. or facilitators.ti,ab,kw.

\#4 1 and 2 and 3

\#5 Limit to English language and humans

AMED and CINAHL via ESBSCO: conducted 29 June 2017

\begin{tabular}{|l|l|}
\hline Search ID & Search terms \\
\hline S1 & parkinson's disease \\
\hline S2 & parkinson* \\
\hline S3 & PD \\
\hline S4 & S1 OR S2 OR S3 [apply equivalent subjects; apply related words] \\
\hline S5 & physical activity \\
\hline S6 & exercise \\
\hline S7 & leisure time physical activity \\
\hline S8 & walking \\
\hline S9 & swimming \\
\hline S10 & tai chi \\
\hline S11 & qigong \\
\hline S12 & yoga \\
\hline S13 & motor activity \\
\hline S14 & motor activity \\
\hline S15 & physical fitness \\
\hline S16 & $\begin{array}{l}\text { S5 OR S6 OR S7 OR S8 OR S9 OR S10 OR S11 OR S12 OR S14 OR S15 [apply } \\
\text { equivalent subjects; apply related words] }\end{array}$ \\
\hline S17 & experiences or perceptions or attitudes or views \\
\hline S18 & preference \\
\hline S19 & adherence or compliance or concordance \\
\hline
\end{tabular}




\begin{tabular}{|l|l|}
\hline \multicolumn{2}{|l|}{ (Continued) } \\
\hline Search ID & Search terms \\
\hline S20 & engagement or involvement or participation \\
\hline S21 & enablers or barriers or facilitators \\
\hline S22 & motivators \\
\hline S23 & S17 OR S18 OR S19 OR S20 OR S22 \\
\hline S24 & S4 AND S16 AND S23 \\
\hline
\end{tabular}

Web of Science: conducted 29 June 2017

\begin{tabular}{|l|l|}
\hline$\# 1$ & $\begin{array}{l}\text { TOPIC: (Parkinson's disease) OR (Parkinson*) or (PD) } \\
\text { Indexes = SCI-EXPANDED, SSCI, A\&HCI, CPCI-SSH, ESCI Timespan = All years }\end{array}$ \\
\hline$\# 2$ & $\begin{array}{l}\text { TOPIC: (physical activity) OR TOPIC: (exercise) OR TOPIC: (physical fitness) OR TOPIC: } \\
\text { (leisure activity) OR TOPIC: (walk*) OR TOPIC: (tai chi) OR TOPIC: (qigong) OR TOPIC: } \\
\text { (yoga) OR TOPIC: (swim*) OR TOPIC: (motor activity) } \\
\text { Indexes = SCI-EXPANDED, SSCI, A\&HCI, CPCI-S, CPCI-SSH, ESCI Timespan = All years }\end{array}$ \\
\hline$\# 3$ & $\begin{array}{l}\text { TOPIC: (experience*) OR TOPIC: (preference*) OR TOPIC: (attitude*) OR TOPIC: (view*) } \\
\text { Indexes = SCI-EXPANDED, SSCI, A\&HCI, CPCI-S, CPCI-SSH, ESCI Timespan = All years }\end{array}$ \\
\hline$\# 4$ & $\begin{array}{l}\text { TOPIC: (participation) OR TOPIC: (engagement) OR TOPIC: (compliance) OR TOPIC: } \\
\text { (concordance) OR TOPIC: (enablers) OR TOPIC: (motivators) OR TOPIC: (facilitators) OR } \\
\text { TOPIC: (barriers) } \\
\text { SCI-EXPANDED, SSCI, A\&HCI, CPCI-S, CPCI-SSH, ESCI Timespan = All years }\end{array}$ \\
\hline$\# 5$ & $\begin{array}{l}\# 1 \text { AND \#2 AND \#3 AND \#4 } \\
\text { SCI-EXPANDED, SSCI, A\&HCI, CPCI-S, CPCI-SSH, ESCI Timespan = All years }\end{array}$ \\
\hline
\end{tabular}

Scopus: conducted 29 June 2017

\begin{tabular}{|l|l|}
\hline$\# 1$ & $\begin{array}{l}\text { "Parkinson's disease” (article title, abstract, keywords) AND "Physical activity" (article title, } \\
\text { abstract, keywords) AND "experience" (article title, abstract, keywords) }\end{array}$ \\
\hline$\# 2$ & Limit Published all years to present \\
\hline
\end{tabular}

Google and MedNar: conducted 30 June 2017

$$
\begin{array}{l|l}
\text { \#1 } & \text { Parkinson's disease physical activity experience } \\
\text { \#2 } & \text { "Parkinson's disease" and "physical activity" and "experience" and "participation" }
\end{array}
$$

Conference Paper Index: conducted 30 June 2017

\#1 Parkinson's disease AND Physical activity AND Experience 
PQDT Open: conducted 30 June 2017

\#1 "Parkinson's disease" and "physical activity"

OpenGrey: conducted 30 June 2017

\#1 Discipline 05* “Parkinson’s disease” Limiter = English 
Appendix IV: Excluded studies with reasons

\begin{tabular}{|c|c|c|}
\hline Author(s) & Title & Exclusion reason \\
\hline $\begin{array}{l}\text { Afshari, M. Kianirad, Y. Bega, } \\
\text { D. } 2016\end{array}$ & $\begin{array}{l}\text { Motivators and barriers to participation in exer- } \\
\text { cise in Parkinson's disease }\end{array}$ & No qualitative data \\
\hline $\begin{array}{l}\text { Onnalin Jandeaw, Priya } \\
\text { Jagota, Surat Singmaneesakul- } \\
\text { chai, Nonglak Boonrod, Lalita } \\
\text { Kaewwilai, et al. } 2014\end{array}$ & $\begin{array}{l}\text { Perception of the disease in patients with Parkin- } \\
\text { son's disease: past, present and future }\end{array}$ & Not phenomena of interest \\
\hline Traeger B.E 2016 & $\begin{array}{l}\text { Identifying the Types of Physical Exercise that } \\
\text { Help Individuals with Parkinson's disease manage } \\
\text { their symptoms: A modified Delphi study }\end{array}$ & PD population not identifiable \\
\hline $\begin{array}{l}\text { Benharoch, J. Wiseman, T. } \\
2004\end{array}$ & $\begin{array}{l}\text { Participation in Occupations: Some Experiences } \\
\text { of People with Parkinson's Disease }\end{array}$ & Not phenomenon of interest \\
\hline $\begin{array}{l}\text { Blandy, L. M. Beevers, W. A. } \\
\text { Fitzmaurice, K. Morris, M. E } \\
2015\end{array}$ & $\begin{array}{l}\text { Argentine tango dancing for people with mild } \\
\text { Parkinson's disease: A feasibility study }\end{array}$ & No qualitative data \\
\hline $\begin{array}{l}\text { Duncan, R. P. Earhart, G. M. } \\
2011\end{array}$ & $\begin{array}{l}\text { Measuring participation in individuals with Par- } \\
\text { kinson disease: relationships with disease severity, } \\
\text { quality of life, and mobility }\end{array}$ & No qualitative data \\
\hline $\begin{array}{l}\text { Ellis, R. Kosma, M. Cardinal, } \\
\text { B. J. Bauer, J. J. McCubbin, J. } \\
\text { A. } 2007\end{array}$ & $\begin{array}{l}\text { Physical activity beliefs and behavior of adults } \\
\text { with physical disabilities }\end{array}$ & PD population not identifiable \\
\hline $\begin{array}{l}\text { Ellis, T. Boudreau, J. K. DeAn- } \\
\text { gelis, T. Brown, L. E. Cava- } \\
\text { naugh, J. T. Earhart, G. M. } \\
\text { Ford, M. P. Foreman, K. B. } \\
\text { Dibble, L. E. } 2013\end{array}$ & $\begin{array}{l}\text { Barriers to exercise in people with Parkinson } \\
\text { disease }\end{array}$ & No qualitative data \\
\hline $\begin{array}{l}\text { Ellis, T. Latham, N. K. DeAn- } \\
\text { gelis, T. R. Thomas, C. A. } \\
\text { Saint-Hilaire, M. Bickmore, T. } \\
\text { W. } 2013\end{array}$ & $\begin{array}{l}\text { Feasibility of a virtual exercise coach to promote } \\
\text { walking in community-dwelling persons with } \\
\text { Parkinson disease }\end{array}$ & No qualitative data \\
\hline $\begin{array}{l}\text { Englert, D. Hirsch, M. Sanjak, } \\
\text { M. Russo, P. Quinlan, M. } \\
\text { Crum, K. Iyer, S. } 2013\end{array}$ & $\begin{array}{l}\text { Barriers to physical activity among adults with } \\
\text { idiopathic Parkinson's disease (PD) }\end{array}$ & No qualitative data \\
\hline Estivill, M. 1995 & $\begin{array}{l}\text { Therapeutic aspects of aerobic dance participa- } \\
\text { tion }\end{array}$ & Not PD population \\
\hline $\begin{array}{l}\text { Fujimoto, K. I. Murata, M. } \\
\text { Hattori, N. Kondo, T. } 2016\end{array}$ & $\begin{array}{l}\text { Patients' perspective on Parkinson disease thera- } \\
\text { pies: Comparative results of large-scale surveys in } \\
2008 \text { and } 2013 \text { in Japan }\end{array}$ & $\begin{array}{l}\text { Not in English - no transla- } \\
\text { tion available }\end{array}$ \\
\hline $\begin{array}{l}\text { Garretto, N. Arce, M. } \\
\text { Arakaki, T. Abaroa, L. } \\
\text { Frola, P. Oliveri, M. } \\
\text { Moreno, C. R. Rabinovich, D. } \\
2011\end{array}$ & $\begin{array}{l}\text { Argentine tango as therapy for Parkinson's dis- } \\
\text { ease (PD) }\end{array}$ & No qualitative data \\
\hline $\begin{array}{l}\text { Grosset, K. A. Grosset, D. G. } \\
2005\end{array}$ & $\begin{array}{l}\text { Patient-perceived involvement and satisfaction in } \\
\text { Parkinson's disease: Effect on therapy decisions } \\
\text { and quality of life }\end{array}$ & No qualitative data \\
\hline
\end{tabular}




\section{(Continued)}

Author(s)

Hirsch M.A, Sanjay SI., Englert D., and Sanjak M. 2011

Houston S., and McGill A 2013

Jette, A. M. Keysor, J. Coster, W. Ni, P. Haley, S. 2005

Koch, S. C. Mergheim, K. Raeke, J. Machado, C. B. Riegner, E. Nolden, J. Dierlecke, T. K. 2016

Lakes, K. D. Marvin, S. Rowley, J. San Nicolas, M. Arastoo, S. Viray, L. Orozco, A. Jurnak, F. 2016

Landers, M. R. Lopker, M. Newman, M. Gourlie, R. Sorensen, S. Vong, R. 2017

Li, F. Harmer, P. Fisher, K. J. $\mathrm{Xu}$, J. Fitzgerald, K. Vongjaturapat, N. 2007

Li, F. Harmer, P. Liu, Y. Eckstrom, E. Fitzgerald, K. Stock, R. Chou, L. S. 2014 Liao, Y. C. Wu, Y. R. Tsao, L. I. Lin, H. R. 2013

Loprinzi, P. D. Darnell, T. Hager, K. Vidrine, J. I. 2015

Lyons, K. E. Pahwa, R. 2007

Malone, L. A. Barfield, J. P. Brasher, J. D. 2012 mayr, G. von Moreau, D. Hil-

\section{Title}

Promoting exercise in Parkinson's disease through community-based participatory research

A mixed methods study into ballet for people living with Parkinson's.
Exclusion reason

No qualitative data

Later study published in 2015, which utilized same participants. Limited qualitative data presented

McNeely, M. E. Duncan, R. P. Earhart, G. M. 2015

Mulligan, H. Whitehead, L. C. Hale, L. A. Baxter, G. D. Thomas, D. 2012
Beyond function: predicting participation in a rehabilitation cohort

The Embodied Self in Parkinson's Disease: Feasibility of a Single Tango Intervention for Assessing Changes in Psychological Health Outcomes and Aesthetic Experience

Dancer perceptions of the cognitive, social, emotional, and physical benefits of modern styles of partnered dancing

A Cross-sectional Analysis of the Characteristics of Individuals With Parkinson Disease Who

Avoid Activities and Participation Due to Fear of Falling

Tai Chi-based exercise for older adults with

Parkinson's disease: A pilot-program evaluation

A randomized controlled trial of patient-reported outcomes with tai chi exercise in Parkinson's disease

The Experiences of Taiwanese Older Individuals at Different Stages of Parkinson Disease

Physical activity-related beliefs and discrepancies between beliefs and physical activity behavior for various chronic diseases

Electronic motor function diary for patients with Parkinson's disease: a feasibility study

Perceived benefits and barriers to exercise among persons with physical disabilities or chronic health conditions within action or maintenance stages of exercise

PD population not identifiable

Not phenomena of interest not qualitative

Not PD population

Not qualitative data

Not qualitative data

Not phenomena of interest / not qualitative

Not phenomena of interest

Not PD population

Not qualitative not phenomena of interest

Not qualitative data not PD

Not qualitative data ticipation, and quality of life in Parkinson disease and healthy older adults

Promoting physical activity for individuals with neurological disability: indications for practice
PD participants are not identifiable therefore exclude as not population 


\section{(Continued)}

\section{Author(s)}

Natbony, L. R. Zimmer, A. Ivanco, L. S. Studenski, S. A. Jain, S. 2013

Newitt, R. Barnett, F. Crowe, M. 2016

O'Brien C., Canning C.G., and

Clemson L. 2013

O’Brien C. 2014

Pentecost, C. Taket, A. 2011

Pickering, R. M. Fitton, C. Ballinger, C. Fazakarley, L. Ashburn, A. 2013

Shanahan, J. Bhriain, O. Morris, M. E. Volpe, D. Clifford, A. M. 2016

Sjödahl Hammarlund, C. Nilsson, M. H. Hagell, P. 2012

Sorrell, J. M. 2017

Speelman, Arlène D. van Nimwegen, Marlies Bloem, Bastiaan R. Munneke, Marten 2014

Sunwoo, M. K. Lee, J. E. Hong, J. Y. Ye, B. S. Lee, H. S. Oh, J. S. Kim, J. S. Lee, P. H. Sohn, Y. H. 2017

Takahashi, K. 2008

Tan, D. Tan, C. Tan, E. K. Mahfooza, A. 2015

Worthen-Chaudhari, L. C. 2011

\section{Title}

Perceptions of a Videogame-Based Dance Exer-

cise Program Among Individuals with Parkinson's Disease

Understanding factors that influence participation in physical activity among people with a neuromusculoskeletal condition: a review of qualitative studies

Parkinson's disease: The experience of exercise.

Exercise participation in Parkinson's disease: A qualitative study

Understanding exercise uptake and adherence for people with chronic conditions: a new model demonstrating the importance of exercise identity, benefits of attending and support

Self-reported adherence to a home-based exercise program among people with Parkinson's disease

Irish set dancing classes for people with Parkinson's disease: The needs of participants and dance teachers

Measuring outcomes in Parkinson's disease: a multi-perspective concept mapping study

Living with Parkinson's Disease

Evaluation of implementation of the ParkFit program: A multifaceted intervention aimed to promote physical activity in patients with Parkinson's disease

Premorbid exercise engagement and motor reserve in Parkinson's disease

Not phenomena of interest/not

Behavior in Parkinson's disease as related to self- Not enough information efficacy and outcome expectancy

The lived experiences of community dwelling adults with Parkinson's disease towards exercise and participation in a rehabilitation trial

New Partnerships Between Dance and Neuroscience: Embedding the Arts for Neuro recovery qualitative

Exclusion reason

Not qualitative data

PD participants are not identifiable therefore exclude as not Population

Poster presentation: based on full study which was included in systematic review. So duplicate data

Thesis results published in published paper so duplicate data set.

Not PD population

No qualitative data

No qualitative data

Not phenomena of interest

Narrative paper only

No qualitative data

Not enough information

Narrative commentary only 


\section{Appendix V: Characteristics of included studies for methodological review}

\begin{tabular}{|c|c|c|c|c|c|c|}
\hline Author/ year & $\begin{array}{l}\text { Methodology/ } \\
\text { Method }\end{array}$ & $\begin{array}{l}\text { Phenomena } \\
\text { of interest }\end{array}$ & $\begin{array}{l}\text { Participants } \\
\text { Age } \\
\text { gender }\end{array}$ & $\begin{array}{l}\text { Sampling/Setting/Geog- } \\
\text { raphy/culture }\end{array}$ & Conclusions/Outcomes & Reviewer Notes \\
\hline $\begin{array}{l}\text { Bassett, S. Stewart, } \\
\text { J. Giddings, L. } \\
(2012)^{52}\end{array}$ & $\begin{array}{l}\text { Mixed methods } \\
\text { (single case } \\
\text { repeated measures } \\
\text { of five six-week } \\
\text { phases ABACA) } \\
\text { Face to face semi- } \\
\text { structured inter- } \\
\text { view } \\
\text { Content Analysis }\end{array}$ & $\begin{array}{l}\text { Experiences and } \\
\text { effects of the two } \\
\text { types of walking } \\
\text { (Nordic and ordi- } \\
\text { nary) }\end{array}$ & $\begin{array}{l}1 \times 64 \text { year old woman } \\
\text { Time with illness: } 11 \\
\text { years } \\
\text { H \&Y: } 2.5\end{array}$ & $\begin{array}{l}\text { Convenience sample } \\
\text { Community setting } \\
\text { Interview location: not } \\
\text { identified } \\
\text { Geography: New Zeal- } \\
\text { and } \\
\text { Culture: Monoculture }\end{array}$ & $\begin{array}{l}\text { Interview analysis } \\
\text { revealed that the partici- } \\
\text { pant considered Nordic } \\
\text { Walking more beneficial } \\
\text { than ordinary walking; } \\
\text { her general health } \\
\text { improved, and she coped } \\
\text { better with daily activi- } \\
\text { ties }\end{array}$ & $\begin{array}{l}\text { Only one participant as } \\
\text { a single case report. } \\
\text { Qualitative information } \\
\text { extracted from interview }\end{array}$ \\
\hline $\begin{array}{l}\text { Bognar, S., Defaria, } \\
\text { AM. O'Dywer, C } \\
\text { et al. }(2017)^{59}\end{array}$ & $\begin{array}{l}\text { Qualitative descrip- } \\
\text { tive design } \\
\text { Individual semi- } \\
\text { structured inter- } \\
\text { views } \\
\text { Content analysis } \\
\text { with an inductive } \\
\text { analysis method }\end{array}$ & $\begin{array}{l}\text { Experiences and } \\
\text { perceptions of } \\
\text { pwPD who attended } \\
\text { a dance program. }\end{array}$ & $\begin{array}{l}\text { Ten participants with a } \\
\text { diagnosis of PD. } 8 \\
\text { males/ } 2 \text { women } \\
\text { Mean age: not given } \\
\text { Age range } 60-75+ \\
\text { Time with illness: not } \\
\text { obtained } \\
\text { H\&Y: not specified (all } \\
\text { mobile }+/- \text { aid) }\end{array}$ & $\begin{array}{l}\text { Convenience sample } \\
\text { Community setting } \\
\text { Interview location: not } \\
\text { identified } \\
\text { Geography: Canada } \\
\text { Culture - not specified }\end{array}$ & $\begin{array}{l}\text { Dancing with PD classes } \\
\text { allow for re-develop- } \\
\text { ment of the social self, } \\
\text { which can increase sense } \\
\text { of enjoyment in life. } \\
\text { Dance programs provide } \\
\text { opportunities for social } \\
\text { interaction, non-verbal } \\
\text { communication and self- } \\
\text { improvement, re-estab- } \\
\text { lishing self-identify and } \\
\text { a sense of usefulness. }\end{array}$ & $\begin{array}{l}\text { Good description of } \\
\text { dance class, which was } \\
\text { taught by dance instruc- } \\
\text { tor. Participation in } \\
\text { dance class varied from } \\
6 \text { months to } 4 \text { years. } \\
\text { Contacted author for } \\
\text { article. }\end{array}$ \\
\hline $\begin{array}{l}\text { Crizzle, AM., New- } \\
\text { house, IJ. }(2012)^{5}\end{array}$ & $\begin{array}{l}\text { Qualitative meth- } \\
\text { odology } \\
\text { Semi-structured } \\
\text { focus group, with } \\
\text { observation of } \\
\text { behaviors and } \\
\text { facial expression. } \\
\text { Moderator with no } \\
\text { affiliation to proj- } \\
\text { ect conducted the } \\
\text { focus group } \\
\text { Content Analysis }\end{array}$ & $\begin{array}{l}\text { Motivators and bar- } \\
\text { riers to exercise } \\
\text { adherence } 1 \text { week } \\
\text { post hydrotherapy } \\
\text { program completion }\end{array}$ & $\begin{array}{l}\text { Four participants with } \\
\text { PD. } 2 \text { men/2 women } \\
\text { Mean age } 75.8 \text { (range } \\
71 \text { to } 89 \text { ) } \\
4 \text { caregivers ( } 2 \text { spouse, } 1 \\
\text { daughter, } 1 \text { son) } \\
\text { Mean time since diagno- } \\
\text { sis: not given } \\
\text { H\&Y: } 2 \text { (stage } 3 \text { ) } 2 \\
\text { (stage } 2 \text { ) } \\
\text { Mobility: } 2 \text { independent; } \\
1 \text { cane; } 1 \text { walker }\end{array}$ & $\begin{array}{l}\text { Sampling: convenience } \\
\text { Setting: community } \\
\text { Interview location: not } \\
\text { specified } \\
\text { Geography: Canada. } \\
\text { Culture - not specified }\end{array}$ & $\begin{array}{l}\text { Main theme: Constant } \\
\text { reassurance and encour- } \\
\text { agement needed from } \\
\text { instructor motivated PD } \\
\text { participants to continue. } \\
\text { Motivation: exercising } \\
\text { in a group environment } \\
\text { with pwPD; tailored } \\
\text { exercise program for } \\
\text { both physical and psy- } \\
\text { chological needs. }\end{array}$ & $\begin{array}{l}\text { Exercise program was } \\
\text { hydrotherapy and parti- } \\
\text { cipants exercised } 3 \text { times } \\
\text { a week for } 6 \text { weeks. } \\
\text { Focus groups included } \\
\text { pwPD and their carers. } \\
\text { However only informa- } \\
\text { tion from pwPD } \\
\text { extracted. }\end{array}$ \\
\hline $\begin{array}{l}\text { Davis, JT. Erbart, } \\
\text { A. Trcinski, BH } \\
\text { et al. }(2003)^{58}\end{array}$ & $\begin{array}{l}\text { Qualitative meth- } \\
\text { odology } \\
\text { Focus groups } \times 2 \\
\text { Semi structured. } \\
\text { Video and audio } \\
\text { taped }\end{array}$ & $\begin{array}{l}\text { Self-perceived physi- } \\
\text { cal limitations and } \\
\text { compensatory strat- } \\
\text { egies of living with } \\
\text { PD. }\end{array}$ & $\begin{array}{l}\text { Nine participants with } \\
\text { PD. } 6 \text { men/3 women } \\
\text { Mean age: } 70.6 \text { (range } \\
51-85 \text { ) } \\
\text { mean time since diagno- } \\
\text { sis: } 9.9 \text { years (range } 3 \text { to } \\
20 \text { years) } \\
\text { H\&Y: not given } \\
\text { Mobility: all ambulatory } \\
\text { either independent/cane } \\
\text { or walker }\end{array}$ & $\begin{array}{l}\text { Sampling: convenience. } \\
\text { Setting: community } \\
\text { Interview location: local } \\
\text { church } \\
\text { Geography: USA } \\
\text { Culture: not specified }\end{array}$ & $\begin{array}{l}3 \text { themes: variability of } \\
\text { experiences among } \\
\text { pwPD; variability in } \\
\text { compensatory and cop- } \\
\text { ing strategies; and the } \\
\text { inadequacy of health } \\
\text { care system in addres- } \\
\text { sing needs. }\end{array}$ & $\begin{array}{l}\text { Participants not attend- } \\
\text { ing exercise group but } \\
\text { views on PA undertak- } \\
\text { ing functional activities. }\end{array}$ \\
\hline $\begin{array}{l}\text { Elsworth, C. } \\
\text { Dawes, H. Sackley, } \\
\text { C. et al. }(2009)^{42}\end{array}$ & $\begin{array}{l}\text { Qualitative meth- } \\
\text { odology } \\
\text { Focus group semi- } \\
\text { structured. } \\
\text { Notes taken by } 3 \\
\text { researchers. } \\
\text { Analysis: content } \\
\text { analysis }\end{array}$ & $\begin{array}{l}\text { Opinions of individ- } \\
\text { uals with progres- } \\
\text { sive neurological } \\
\text { disorders on exer- } \\
\text { cise, barriers and } \\
\text { facilitator for PA } \\
\text { within community } \\
\text { settings }\end{array}$ & $\begin{array}{l}\text { Six participants with PD } \\
\text { Mean age: not available } \\
\text { for PD focus group } \\
\text { alone. } \\
\text { Mean time since diagno- } \\
\text { sis: not given } \\
\text { H\&Y: not given } \\
\text { Mobility: not given. }\end{array}$ & $\begin{array}{l}\text { Sampling: convenience. } \\
\text { Setting: community } \\
\text { Geography: UK Inter- } \\
\text { view location: confer- } \\
\text { ence room University } \\
\text { Geography: UK, } \\
\text { Oxfordshire } \\
\text { Culture: not specified }\end{array}$ & $\begin{array}{l}\text { PD: barriers } \\
\text { Difficulty moving about } \\
\text { in public spaces. Medi- } \\
\text { cation affects timing of } \\
\text { exercise sessions and } \\
\text { coordination and consid- } \\
\text { eration is needed at to } \\
\text { when in should be } \\
\text { taken. Pool temperature } \\
\text { too cold. Losing balance }\end{array}$ & $\begin{array}{l}\text { Study included partici- } \\
\text { pants with a variety of } \\
\text { neurological conditions. } \\
\text { However only analysis } \\
\text { of PD information } \\
\text { reviewed. As none of the } \\
\text { findings were supported } \\
\text { by an illustration no } \\
\text { data was able to be } \\
\text { extracted for further } \\
\text { synthesis. }\end{array}$ \\
\hline
\end{tabular}




\begin{tabular}{|c|c|c|c|c|c|c|}
\hline \multicolumn{7}{|l|}{ (Continued) } \\
\hline Author/ year & $\begin{array}{l}\text { Methodology/ } \\
\text { Method }\end{array}$ & $\begin{array}{l}\text { Phenomena } \\
\text { of interest }\end{array}$ & $\begin{array}{l}\text { Participants } \\
\text { Age } \\
\text { gender }\end{array}$ & $\begin{array}{l}\text { Sampling/Setting/Geog- } \\
\text { raphy/culture }\end{array}$ & Conclusions/Outcomes & Reviewer Notes \\
\hline $\begin{array}{l}\text { Erikson, BM. Arne, } \\
\text { M. Ahlgren, C } \\
(2013)^{44}\end{array}$ & $\begin{array}{l}\text { Constructivist Par- } \\
\text { adigm } \\
\text { Grounded theory } \\
\text { methodology } \\
\text { One to one semi- } \\
\text { structured inter- } \\
\text { view } \\
\text { Audio taped and } \\
\text { transcribed }\end{array}$ & $\begin{array}{l}\text { Meaning of physical } \\
\text { exercise in pwPD }\end{array}$ & $\begin{array}{l}11 \text { participants with PD } \\
\text { who were active in exer- } \\
\text { cise programs for }>1 \\
\text { year } \\
6 \text { men } 15 \text { women. } \\
\text { Median age } 75 \text { years } \\
\text { (range } 61-81 \text { ) } \\
\text { Median years since diag- } \\
\text { nosis } 8 \text { years (range 2- } \\
\text { 17) } \\
\text { H\&Y: ranged from 1-4 } \\
\text { Mobility: independent } \\
\text { with/with aid } \\
\text { H\&Y Stages } 1-2 \text { partic- } \\
\text { ipated in aerobic exer- } \\
\text { cise class. Stages 3-4 } \\
\text { participated in Circuit } \\
\text { exercise class }\end{array}$ & $\begin{array}{l}\text { Sampling: Purposive } \\
\text { (gender, years since } \\
\text { diagnosis, grade of } \\
\text { impairment) } \\
\text { Setting: community } \\
\text { Interview location: parti- } \\
\text { cipants home/physio } \\
\text { department/public place } \\
\text { dependent on choice. } \\
\text { Geography: Sweden } \\
\text { Culture: not specified }\end{array}$ & $\begin{array}{l}\text { One core category "keep } \\
\text { moving to retain the } \\
\text { health self" } \\
\text { Six categories: } \\
\text { "Having explicit life } \\
\text { goals" \&" "Having confi- } \\
\text { dence in one's ability" } \\
\text { (adherence to PA) Tak- } \\
\text { ing rational position"" } \\
\text { (starting point for exer- } \\
\text { cise habits) } \\
\text { "Exercise to slow pro- } \\
\text { gression" "Exercise to } \\
\text { achieve wellbeing" } \\
\text { "Using exercise as a } \\
\text { coping strategy" (factors } \\
\text { for PA adherence) }\end{array}$ & $\begin{array}{l}\text { Clear methodology with } \\
\text { a theory produced from } \\
\text { the data. Participant } \\
\text { voice represented } \\
\text { through quotes but } \\
\text { examples of codes/illus- } \\
\text { trations quite concise. } \\
\text { Three findings did not } \\
\text { have an illustration and } \\
\text { were therefore not } \\
\text { included in the data } \\
\text { extraction and subse- } \\
\text { quent analysis }\end{array}$ \\
\hline $\begin{array}{l}\text { Hammarlund, CS. } \\
\text { Anderson K. } \\
\text { Anderson, M. et al. } \\
(2014)^{48}\end{array}$ & $\begin{array}{l}\text { Qualitative meth- } \\
\text { odology } \\
\text { Method: Semi- } \\
\text { structured inter- } \\
\text { views } \\
\text { Recorded and tran- } \\
\text { scribed } \\
\text { Analysis: system- } \\
\text { atic text condensa- } \\
\text { tion }\end{array}$ & $\begin{array}{l}\text { Significance of } \\
\text { walking }\end{array}$ & $\begin{array}{l}\text { Eleven participants with } \\
\text { PD } \\
7 \text { men/4 women } \\
\text { Median age: } 71 \\
\text { Median years since diag- } \\
\text { nosis: } 7 \text { years } \\
\text { H\&Y: stages } 2-5 \\
\text { Mobility: walking but } \\
\text { balance impairments } \\
\text { and } 4 \text { used walking aids }\end{array}$ & $\begin{array}{l}\text { Sampling: purposive (PD } \\
\text { severity, gender, age) } \\
\text { Setting: Community set- } \\
\text { ting } \\
\text { Interview location; } \\
\text { home } \\
\text { Geography: Sweden } \\
\text { Culture: not specified }\end{array}$ & $\begin{array}{l}5 \text { categories: } \\
\text { Changed walking abil- } \\
\text { ity, Emotional reactions, } \\
\text { Strategies to manage the } \\
\text { impact of walking diffi- } \\
\text { culties, Social conse- } \\
\text { quences, and } \\
\text { Independence and integ- } \\
\text { rity. } \\
\text { The ability to walk has } \\
\text { a complex and multifac- } \\
\text { eted impact, including } \\
\text { physical and emotional } \\
\text { aspects, as well as inde- } \\
\text { pendence and to partici- } \\
\text { pate in society. Impaired } \\
\text { gait afflicts internal and } \\
\text { external representation } \\
\text { and a negative psycho- } \\
\text { logical impact on self- } \\
\text { concept and coping abil- } \\
\text { ities. The sense of being } \\
\text { able to walk without } \\
\text { help appears to be inti- } \\
\text { mately linked to an indi- } \\
\text { vidual social identity } \\
\text { and emotional wellbe- } \\
\text { ing, integrity and pre- } \\
\text { sumably QoL }\end{array}$ & $\begin{array}{l}\text { Data analysis well } \\
\text { described. Participant } \\
\text { voice strongly repre- } \\
\text { sented with illustrations } \\
\text { for each theme/category. }\end{array}$ \\
\hline $\begin{array}{l}\text { Hislop, J. Gray, S. } \\
\text { Melling, S. et al. } \\
(2015)^{53}\end{array}$ & $\begin{array}{l}\text { Mixed methods } \\
\text { Focus group } \\
\text { Analysis: thematic }\end{array}$ & $\begin{array}{l}\text { Barriers and facilita- } \\
\text { tors to PA and the } \\
\text { experience of } \\
\text { attending a long } \\
\text { term exercise group }\end{array}$ & $\begin{array}{l}\text { Eight participants with } \\
\text { PD ( } 4 \text { males/4 females) } \\
\text { Mean age: } 71 \text { years } \\
\text { Minimum time since } \\
\text { diagnosis } 6 \text { years. } \\
\text { H\&Y: not stated }\end{array}$ & $\begin{array}{l}\text { Sampling: convenience } \\
\text { Setting: not stated } \\
\text { Interview location: not } \\
\text { stated. } \\
\text { Geography: UK } \\
\text { Culture: not specified }\end{array}$ & $\begin{array}{l}\text { Four key themes: Bene- } \\
\text { fits of attending the } \\
\text { group; The group as a } \\
\text { motivator; Factors con- } \\
\text { tributing to long-term } \\
\text { success of the group } \\
\text { included social support, } \\
\text { fun, ownership of and } \\
\text { accountability to the } \\
\text { group; Barriers were } \\
\text { identified as transport } \\
\text { difficulties and the psy- } \\
\text { chological effect of see- } \\
\text { ing people with more } \\
\text { advanced PD }\end{array}$ & $\begin{array}{l}\text { Search results identified } \\
\text { abstract from poster pre- } \\
\text { sentation. Author con- } \\
\text { tacted but no reply. } \\
\text { Subsequently research } \\
\text { summary of study found } \\
\text { published on author's } \\
\text { university website. Only } \\
\text { one finding was sup- } \\
\text { ported by participant } \\
\text { voice and subsequently } \\
\text { extracted for analysis }\end{array}$ \\
\hline
\end{tabular}




\begin{tabular}{|c|c|c|c|c|c|c|}
\hline \multicolumn{7}{|l|}{ (Continued) } \\
\hline Author/ year & $\begin{array}{l}\text { Methodology/ } \\
\text { Method }\end{array}$ & $\begin{array}{l}\text { Phenomena } \\
\text { of interest }\end{array}$ & $\begin{array}{l}\text { Participants } \\
\text { Age } \\
\text { gender }\end{array}$ & $\begin{array}{l}\text { Sampling/Setting/Geog- } \\
\text { raphy/culture }\end{array}$ & Conclusions/Outcomes & Reviewer Notes \\
\hline $\begin{array}{l}\text { Houston, S. McGill } \\
\text { A. Lee, R. et al. } \\
(2015)^{47}\end{array}$ & $\begin{array}{l}\text { Mixed methods } \\
\text { Semi structured } \\
\text { one to one Inter- } \\
\text { views / } \\
\text { focus groups/dia- } \\
\text { ries /observation } \\
\text { Thematic analysis }\end{array}$ & $\begin{array}{l}\text { Perceptions and } \\
\text { experiences of } \\
\text { pwPD dancing and } \\
\text { value of dance pro- } \\
\text { gram (ballet) }\end{array}$ & $\begin{array}{l}53 \text { participants } \\
\text { Mix of male and female } \\
\text { Majority of Age range } \\
60-80 \\
\text { Mean time since diagno- } \\
\text { sis: not given } \\
\text { H\&Y stage not stated } \\
\text { Mobility: independent }\end{array}$ & $\begin{array}{l}\text { Sampling: convenience } \\
\text { Setting: community } \\
\text { Focus group: at dance } \\
\text { center } \\
\text { Geography: UK } \\
\text { Culture: not specified }\end{array}$ & $\begin{array}{l}\text { Themes; fluidity of } \\
\text { movement; balance and } \\
\text { stability; posture; } \\
\text { improved sense of physi- } \\
\text { cal health; cognitive } \\
\text { functioning; aid to daily } \\
\text { life. } \\
\text { Motivation to keep } \\
\text { coming: inclusion and } \\
\text { community, group moti- } \\
\text { vation and bonding; } \\
\text { expression; quality; } \\
\text { uniqueness; intellectual } \\
\text { and physical challenge; } \\
\text { feeling good and feeling } \\
\text { capable; dance educa- } \\
\text { tion; music. } \\
\text { Certainty about the } \\
\text { future: make some posi- } \\
\text { tive changes in your life } \\
\text { and manage your situa- } \\
\text { tion so you can continue } \\
\text { to do things you enjoy; } \\
\text { have hope for the future; } \\
\text { enjoy new things; sense } \\
\text { of achievement; develop } \\
\text { more confidence; have } \\
\text { fun and make friends; } \\
\text { develop a community } \\
\text { with others with PD. } \\
\text { Interference of symp- } \\
\text { toms on everyday life: } \\
\text { Freedom: } \\
\text { Social participation: } \\
\text { Conclusion } \\
\text { Dance program offers } \\
\text { an activity and cultural } \\
\text { experience, which is } \\
\text { multifaceted. Partici- } \\
\text { pants engage for many } \\
\text { reasons and find great } \\
\text { significance in attending } \\
\text { regularly. Dancing helps } \\
\text { pwPD to nurture an } \\
\text { active lifestyle not just } \\
\text { physical but also the } \\
\text { psychological, emotional } \\
\text { and social side }\end{array}$ & $\begin{array}{l}\text { Two studies published } \\
\text { on the same group of } \\
\text { participants. The } 2013 \\
\text { study described the } \\
\text { methodology in detail } \\
\text { but participant voice } \\
\text { was limited. } \\
\text { Data were extracted } \\
\text { from the } 2015 \text { study } 2 \text {, } \\
\text { which was the final } \\
\text { report on the 3-year } \\
\text { mixed methods study. } \\
\text { The English National } \\
\text { Ballet Dance for Parkin- } \\
\text { son's program lasted for } \\
12 \text { weeks. Qualitative } \\
\text { data was gathered } \\
\text { through multiple inter- } \\
\text { views, focus groups and } \\
\text { participant observation. } \\
\text { Only the qualitative } \\
\text { data from participants } \\
\text { with supporting illustra- } \\
\text { tions were extracted and } \\
\text { subsequently analyzed. }\end{array}$ \\
\hline $\begin{array}{l}\text { Jones, D. Roche- } \\
\text { ster, L. Birleson, A. } \\
\text { et al. }(2008)^{50}\end{array}$ & $\begin{array}{l}\text { Qualitative study } \\
\text { (part of mixed } \\
\text { methods) } \\
\text { Semi-structured } \\
\text { interviews. Supple- } \\
\text { mented by field } \\
\text { notes } \\
\text { Recorded and tran- } \\
\text { scribed } \\
\text { Analysis: NUD*IST } \\
\text { N6 software }\end{array}$ & $\begin{array}{l}\text { Personal experience } \\
\text { of everyday walk- } \\
\text { ing, challenges and } \\
\text { strategies to com- } \\
\text { pensate for difficul- } \\
\text { ties }\end{array}$ & $\begin{array}{l}\text { Twenty participants } \\
\text { with PD } \\
\text { (12 male/8 female) } \\
\text { Mean age: } 65 \text { (range } \\
50-80 \text { ) } \\
\text { Mean years since diag- } \\
\text { nosis } 10 \text { (range } 2.5-26 \text { ) } \\
\text { H\&Y: mild to moder- } \\
\text { ate. } \\
\text { Mobility: independent }\end{array}$ & $\begin{array}{l}\text { Sampling: Convenience } \\
\text { Setting: unclear } \\
\text { Interview location: parti- } \\
\text { cipants home } \\
\text { Geography: UK Newcas- } \\
\text { tle } \\
\text { Culture: not specified }\end{array}$ & $\begin{array}{l}\text { Key theme: walking } \\
\text { 'plus' was made up of } 3 \\
\text { components. Walking } \\
\text { whilst doing something } \\
\text { else; walking in different } \\
\text { environments; walking } \\
\text { after another activity. } \\
\text { Two key strategies for } \\
\text { addressing challenges: } \\
\text { monitoring walking } \\
\text { using concentration; cor- } \\
\text { recting walking through } \\
\text { generating rhythm and } \\
\text { size of steps. }\end{array}$ & $\begin{array}{l}\text { Part of mixed methods } \\
\text { study. Focus was on } \\
\text { walking but study } \\
\text { included as walking is a } \\
\text { PA activity. Carers were } \\
\text { present during interview } \\
\text { but only findings from } \\
\text { pwPD were extracted } \\
\text { and synthesized for the } \\
\text { analysis. Limited partici- } \\
\text { pant voice for some } \\
\text { findings. Findings } \\
\text { related to carer support } \\
\text { were not extracted. }\end{array}$ \\
\hline
\end{tabular}




\begin{tabular}{|c|c|c|c|c|c|c|}
\hline \multicolumn{7}{|l|}{ (Continued) } \\
\hline Author/ year & $\begin{array}{l}\text { Methodology/ } \\
\text { Method }\end{array}$ & $\begin{array}{l}\text { Phenomena } \\
\text { of interest }\end{array}$ & $\begin{array}{l}\text { Participants } \\
\text { Age } \\
\text { gender }\end{array}$ & $\begin{array}{l}\text { Sampling/Setting/Geog- } \\
\text { raphy/culture }\end{array}$ & Conclusions/Outcomes & Reviewer Notes \\
\hline $\begin{array}{l}\text { Khalil, H. Busse, } \\
\text { M. Quin, L et al. } \\
\text { (2017) }\end{array}$ & $\begin{array}{l}\text { Mixed methods } \\
\text { Interviews } \\
\text { Analysis: thematic }\end{array}$ & $\begin{array}{l}\text { Focus was to } \\
\text { explore feasibility of } \\
\text { intervention - Inter- } \\
\text { vention group com- } \\
\text { pleted } 8 \text { weeks of } \\
\text { home based exercise } \\
\text { and walking pro- } \\
\text { gram. }\end{array}$ & $\begin{array}{l}\text { Sixteen participants with } \\
\text { PD } \\
\text { Intervention group (12 } \\
\text { male } / 4 \text { female) } \\
\text { Mean age } 58.4 \text { (SD } \\
13.5 \text { ) } \\
\text { Time since diagnosis } 8.9 \\
\text { years (SD 6.4) } \\
\text { H\&Y } 2.4 \text { (SD } 0.72 \text { ) }\end{array}$ & $\begin{array}{l}\text { Sampling: Convenience. } \\
\text { Setting: community } \\
\text { Interview location: not } \\
\text { specified } \\
\text { Geography: Jordan } \\
\text { Culture: - mono culture } \\
\text { Arabic }\end{array}$ & $\begin{array}{l}\text { Themes: Enablers; Per- } \\
\text { sonal challenges; cul- } \\
\text { tural challenges }\end{array}$ & $\begin{array}{l}\text { Pilot study. Focus was } \\
\text { on cultural barriers and } \\
\text { motivators to the exer- } \\
\text { cise program. Limited } \\
\text { information re qualita- } \\
\text { tive methodology. Illus- } \\
\text { trative quote given for } \\
\text { every theme }\end{array}$ \\
\hline $\begin{array}{l}\text { Khalil, H. Nazzal, } \\
\text { M. Al-Sheyab, N. } \\
(2016)^{57}\end{array}$ & $\begin{array}{l}\text { Qualitative } \\
\text { Focus groups } \\
\text { ( } \mathrm{n}=6 \text { ) (separate } \\
\text { genders) One to } \\
\text { one interviews } \\
\text { ( } \mathrm{n}=7 \text { ) } \\
\text { Supplemented by } \\
\text { field notes } \\
\text { Recorded and tran- } \\
\text { scribed } \\
\text { Analysis: thematic }\end{array}$ & $\begin{array}{l}\text { Focus on perceived } \\
\text { barriers and motiva- } \\
\text { tors for exercise } \\
\text { participation }\end{array}$ & $\begin{array}{l}\text { Thirteen participants } \\
\text { with PD } \\
\text { (7 male/6 female) } \\
\text { Mean age: } 54.9 \text { (range } \\
38-71 \text { ) } \\
\text { H\&Y: ranged } 1 \text { to } 4 \\
\text { Time since diagnosis: } \\
\text { not stated }\end{array}$ & $\begin{array}{l}\text { Sampling: convenience } \\
\text { and stratified (gender) } \\
\text { Setting: community set- } \\
\text { ting } \\
\text { Interview location: } \\
\text { research center } \\
\text { Geography: Country } \\
\text { Jordan } \\
\text { Culture: mono culture } \\
\text { Arabic }\end{array}$ & $\begin{array}{l}\text { Key theme; lack of pre- } \\
\text { vious participation in } \\
\text { any disease specific exer- } \\
\text { cises; } \\
\text { Barriers: difficulty of } \\
\text { diagnosis; lack of infor- } \\
\text { mation support; lack of } \\
\text { referral to PT; disease } \\
\text { specific issues; and set- } \\
\text { ting related issues. } \\
\text { Motivators: Outcome } \\
\text { expectations; family sup- } \\
\text { port. }\end{array}$ & $\begin{array}{l}\text { Limited detail re qualita- } \\
\text { tive methodology as to } \\
\text { why use of focus groups } \\
\text { and interviews. Data } \\
\text { from Interviews with } \\
\text { neurologist was not } \\
\text { extracted. Findings were } \\
\text { supported by illustrative } \\
\text { quotes from pwPD }\end{array}$ \\
\hline $\begin{array}{l}\text { Kunkel, D. Robin- } \\
\text { son, J. Fitton, C } \\
\text { et al. }(2017)^{54}\end{array}$ & $\begin{array}{l}\text { Qual aspect of } \\
\text { mixed methods } \\
\text { Semi structured } \\
\text { Interviews } \\
\text { (within one month } \\
\text { of completing } \\
\text { dance class) } \\
\text { Thematic analysis }\end{array}$ & $\begin{array}{l}\text { Appropriateness of } \\
\text { dance as an inter- } \\
\text { vention for PwPD. } \\
\text { (experiences and } \\
\text { view about: the } \\
\text { venue/access issues; } \\
\text { instructors teaching } \\
\text { styles; challenges } \\
\text { encountered; per- } \\
\text { ceived impact on } \\
\text { mobility and other } \\
\text { outcomes; interest } \\
\text { in continuing with } \\
\text { dance }\end{array}$ & $\begin{array}{l}7 \text { men (age range } 65- \\
79 \text { ) } \\
7 \text { women (age range } \\
49-81 \text { ) } \\
\text { Time with illness: } 1-14 \\
\text { years. } \\
\text { H\&Y stage: } 1-3\end{array}$ & $\begin{array}{l}\text { Sampling: Purposive } \\
\text { (maximum variation - } \\
\text { age/gender and relation- } \\
\text { ship with dance partner) } \\
\text { Geography UK } \\
\text { Setting: community } \\
\text { dance class } \\
\text { Interview location: parti- } \\
\text { cipant's home. } \\
\text { Culture: not specified }\end{array}$ & $\begin{array}{l}\text { Dance is appropriate } \\
\text { and acceptable to PwPD } \\
\text { and inform plans for } \\
\text { running the dance pro- } \\
\text { gram on a larger scale } \\
\text { for RCT } \\
\text { Views on experience on } \\
\text { being partnered with } \\
\text { their spouse or a volun- } \\
\text { teer/managing potential } \\
\text { sources of tension or } \\
\text { difficulty/views on the } \\
\text { experience of being a } \\
\text { dance partner/views on } \\
\text { continuing with dance } \\
\text { classes }\end{array}$ & $\begin{array}{l}\text { Search strategy identi- } \\
\text { fied conference abstract } \\
\text { and author contacted } \\
\text { for more detail. This } \\
\text { resulted in the inclusion } \\
\text { of this published paper } \\
\text { from one of the authors. } \\
\text { Study included data } \\
\text { from dance partners but } \\
\text { only data extracted with } \\
\text { from pwPD }\end{array}$ \\
\hline $\begin{array}{l}\text { O'Brien, C. Clem- } \\
\text { son, L. Caning CG. } \\
(2016)^{45}\end{array}$ & $\begin{array}{l}\text { Interpretivist Con- } \\
\text { structivist Para- } \\
\text { digm } \\
\text { Grounded theory } \\
\text { methodology. } \\
\text { One to one semi- } \\
\text { structured inter- } \\
\text { views } \\
\text { Recorded and tran- } \\
\text { scribed } \\
\text { Grounded theory - } \\
\text { theoretical model } \\
\text { provided }\end{array}$ & $\begin{array}{l}\text { Focus: meaning of } \\
\text { exercise and how } \\
\text { other factors inter- } \\
\text { act and influence } \\
\text { exercise behavior of } \\
\text { individuals with PD }\end{array}$ & $\begin{array}{l}\text { Subset of individuals } \\
\text { with PD who had been } \\
\text { enrolled in the } 6 / 12 \\
\text { exercise arm of a falls } \\
\text { prevention trial. } \\
\text { Eight participants ( } 6 \\
\text { male/ } 2 \text { female) } 2 \text { partici- } \\
\text { pants completed exercise } \\
\text { program and } 6 \text { did not. } \\
\text { Age }>40 \text { years old } \\
\text { H\&Y either } 2 \text { or } 3 \\
\text { Time since diagnosis: } \\
\text { range } 3 \text { to } 11 \text { years }\end{array}$ & $\begin{array}{l}\text { Sampling: Convenience. } \\
\text { Setting: community } \\
\text { Location of interview: } \\
\text { patient's homes. } \\
\text { Geography: Australia } \\
\text { Culture: not specified }\end{array}$ & $\begin{array}{l}4 \text { main themes: adapting } \\
\text { to change and loss, the } \\
\text { influence of others, } \\
\text { making sense of the } \\
\text { exercise experience, and } \\
\text { hope for a more active } \\
\text { future } \\
3 \text { new influences on } \\
\text { exercise participation: } \\
\text { non-motor impairments } \\
\text { of apathy and fatigue, } \\
\text { the belief in a finite } \\
\text { energy quota, and the } \\
\text { importance of feedback }\end{array}$ & $\begin{array}{l}\text { Search strategy identi- } \\
\text { fied a published PhD } \\
\text { thesis, a poster presenta- } \\
\text { tion and a published } \\
\text { research article, which } \\
\text { was included in the the- } \\
\text { sis. Poster presentation } \\
\text { not included as not } \\
\text { enough detail. To pre- } \\
\text { vent duplication, data } \\
\text { from the published } \\
\text { research article was only } \\
\text { used } \\
\text { Exercise program was } \\
\text { completed unsupervised } \\
\text { at home } 3 \times \text { a week and } \\
\text { supervised } 1 \times \text { month } \\
\text { and last } 6 \text { months. } \\
\text { All findings were sup- } \\
\text { ported by illustrations }\end{array}$ \\
\hline
\end{tabular}




\begin{tabular}{|c|c|c|c|c|c|c|}
\hline \multicolumn{7}{|l|}{ (Continued) } \\
\hline Author/ year & $\begin{array}{l}\text { Methodology/ } \\
\text { Method }\end{array}$ & $\begin{array}{l}\text { Phenomena } \\
\text { of interest }\end{array}$ & $\begin{array}{l}\text { Participants } \\
\text { Age } \\
\text { gender }\end{array}$ & $\begin{array}{l}\text { Sampling/Setting/Geog- } \\
\text { raphy/culture }\end{array}$ & Conclusions/Outcomes & Reviewer Notes \\
\hline $\begin{array}{l}\text { O’Brien, M. Dodd, } \\
\text { KJ. Bilney, B } \\
(2008)^{46}\end{array}$ & $\begin{array}{l}\text { Phenomenological } \\
\text { theoretical frame- } \\
\text { work and a } \\
\text { grounded theory } \\
\text { methodology } \\
\text { Semi -structured: } \\
\text { One to one inter- } \\
\text { views }\end{array}$ & $\begin{array}{l}\text { Focus: positive and } \\
\text { negative aspects and } \\
\text { outcomes of a com- } \\
\text { munity based pro- } \\
\text { gressive resistance } \\
\text { strengthening pro- } \\
\text { gram (PRST), moti- } \\
\text { vators to begin and } \\
\text { continue, barriers to } \\
\text { participate and/or } \\
\text { complete }\end{array}$ & $\begin{array}{l}\text { Twelve out of } 13 \text { parti- } \\
\text { cipants with PD (2 } \\
\text { female and } 10 \text { men) } \\
\text { who participated in a } \\
\text { 10-week community } \\
\text { based PRST program } \\
\text { participated in inter- } \\
\text { views. } \\
\text { Mean Age: } 67.8 \text { (range } \\
50-76 \text { ) } \\
\text { Time since diagnosis } \\
\text { Months: range } 2-192 \\
\text { H\&Y stages } 1-4 \\
\text { (though this included all } \\
\text { participants - not just } \\
\text { the } 12 \text { who were inter- } \\
\text { viewed) } \\
\text { Mobility: mobile }\end{array}$ & $\begin{array}{l}\text { Sampling: Convenience } \\
\text { Setting: community } \\
\text { Location of interview: } \\
\text { not stated } \\
\text { Geography: Australia } \\
\text { Culture: - not specified }\end{array}$ & $\begin{array}{l}4 \text { themes: Motivators } \\
\text { for participation in } \\
\text { PRST were broader than } \\
\text { physical outcomes; the } \\
\text { outcomes were broader } \\
\text { than just physical out- } \\
\text { comes; the indicator of } \\
\text { success for participants } \\
\text { varied and the partici- } \\
\text { pants' experience of a } \\
\text { disease specific exercise } \\
\text { program was positive }\end{array}$ & $\begin{array}{l}\text { PRST program well } \\
\text { described. Study under- } \\
\text { taken in conjunction } \\
\text { with quantitative review } \\
\text { of PRST program. Study } \\
\text { identified and described } \\
\text { theoretical framework } \\
\text { and methodology. All } \\
\text { themes were supported } \\
\text { by participant voice - } \\
\text { though some findings } \\
\text { were better supported } \\
\text { with illustrations than } \\
\text { others. }\end{array}$ \\
\hline $\begin{array}{l}\text { Pretzer-Aboff, I. } \\
\text { Galik, E. Resnick } \\
\text { B. }(2009)^{51}\end{array}$ & $\begin{array}{l}\text { Grounded Theory: } \\
\text { One to one semi- } \\
\text { structured inter- } \\
\text { views (with excep- } \\
\text { tion of a couple } \\
\text { interviewed } \\
\text { together). } \\
\text { Content analysis }\end{array}$ & $\begin{array}{l}\text { Focus: facilitators } \\
\text { and barriers that } \\
\text { pwPD encounter in } \\
\text { trying to optimize } \\
\text { participation in } \\
\text { functional activities } \\
\text { and exercise. }\end{array}$ & $\begin{array}{l}\text { Three people diagnosed } \\
\text { with PD ( } 2 \text { male and } 1 \\
\text { female) and } 7 \text { caregivers. } \\
\text { Data analyzed together. } \\
\text { Mean age: unable to } \\
\text { obtain data } \\
\text { Time since diagnosis: } \\
\text { unable to obtain data } \\
\text { H\&Y }\end{array}$ & $\begin{array}{l}\text { Sampling: purposive } \\
\text { selected (PD and carers) } \\
\text { Setting: community. } \\
\text { Interview location: } \\
\text { quiet, private place. } \\
\text { Geography: USA } \\
\text { Culture: not specified }\end{array}$ & $\begin{array}{l}5 \text { themes: Personality } \\
\text { components, Physiologi- } \\
\text { cal symptoms, Commu- } \\
\text { nication difficulties; } \\
\text { Environmental factors, } \\
\text { Tricks of the trade to } \\
\text { optimize function }\end{array}$ & $\begin{array}{l}\text { Participants and care- } \\
\text { givers interviewed } \\
\text { together. Only informa- } \\
\text { tion from pwPD with } \\
\text { illustrative quotes were } \\
\text { extracted and synthe- } \\
\text { sized - themes } 1-4 \text {. } \\
\text { Clear section, which } \\
\text { described the process for } \\
\text { credibility and confirm- } \\
\text { ability of qualitative } \\
\text { date. }\end{array}$ \\
\hline $\begin{array}{l}\text { Quinn, L. Busse, } \\
\text { M. Khalil H. et al. } \\
(2010)^{56}\end{array}$ & $\begin{array}{l}\text { Qualitative Design } \\
\text { One to one semi- } \\
\text { structured inter- } \\
\text { view } \\
\text { Recorded and tran- } \\
\text { scribed. } \\
\text { Analysis: grounded } \\
\text { theory. }\end{array}$ & $\begin{array}{l}\text { Focus: attitudes and } \\
\text { experiences of early } \\
\text { to mid PD in partic- } \\
\text { ipating in indepen- } \\
\text { dent exercise } \\
\text { programs, identifi- } \\
\text { cation of barriers. }\end{array}$ & $\begin{array}{l}\text { Part of study on pwPD } \\
\text { and Huntington's dis- } \\
\text { ease. } \\
\text { Data from PwPD (n-=5) } \\
1 \text { female/ } 4 \text { male. Data } \\
\text { analyzed together but } \\
\text { able to determine PD } \\
\text { specific quotes } \\
\text { H\&Y early to mid- } \\
\text { stage. } \\
\text { Time since onset symp- } \\
\text { toms: range } 1-9 \text { years } \\
\text { Age range: } 50-60 \\
\text { Mobility: independent } \\
\text { without aids. }\end{array}$ & $\begin{array}{l}\text { Sampling; purposive } \\
\text { early to mid-stage PD } \\
\text { from research database. } \\
\text { Setting: community } \\
\text { Interview location: } \\
\text { patient's homes. } \\
\text { Geography: UK } \\
\text { Culture: not specified }\end{array}$ & $\begin{array}{l}2 \text { main themes: Barriers } \\
\text { to engaging in self- } \\
\text { directed home exercise: } \\
\text { disease specific limita- } \\
\text { tions/safety/location of } \\
\text { exercise } \\
\text { Theme 2: strategies for } \\
\text { motivation: setting tar- } \\
\text { gets and having knowl- } \\
\text { edge of benefits of } \\
\text { exercise/internal motiva- } \\
\text { tion }\end{array}$ & $\begin{array}{l}\text { Only data from pwPD, } \\
\text { which was supported by } \\
\text { illustrative quotes, was } \\
\text { extracted and synthe- } \\
\text { sized }\end{array}$ \\
\hline $\begin{array}{l}\text { Ramasamy, B. } \\
(2015)^{41}\end{array}$ & $\begin{array}{l}\text { Qualitative study: } \\
\text { Participatory } \\
\text { action research } \\
\text { Focus groups } \\
\text { Thematic analysis }\end{array}$ & $\begin{array}{l}\text { Focus to investigate } \\
\text { exercise class partic- } \\
\text { ipant motives for } \\
\text { engaging and con- } \\
\text { tinuing participation } \\
\text { in exercise classes }\end{array}$ & $\begin{array}{l}\text { Numbers and stages of } \\
\text { PD not given }\end{array}$ & $\begin{array}{l}\text { Sampling: included peo- } \\
\text { ple with PD and their } \\
\text { spouses, } \\
3 \text { exercise groups (aqua- } \\
\text { aerobic, circuits and } \\
\text { posture group) } \\
\text { Setting: community } \\
\text { Interview setting: not } \\
\text { stated. } \\
\text { Geography: UK } \\
\text { Cultural: not specified }\end{array}$ & $\begin{array}{l}4 \text { themes identified: } \\
\text { Communication: was a } \\
\text { hit and miss issue, and } \\
\text { sometimes needs to be } \\
\text { better/consistent. Educa- } \\
\text { tion: Saw elements of } \\
\text { both people learning } \\
\text { and teaching one } \\
\text { another } \\
\text { Personalities: the humor/ } \\
\text { optimism /inspiration } \\
\text { from the group mem- } \\
\text { bers, the atmosphere of } \\
\text { support, from class lea- } \\
\text { ders and their character- } \\
\text { istics came out as } \\
\text { important. } \\
\text { Other support: social } \\
\text { elements, shared experi- } \\
\text { ence and committee } \\
\text { back up. }\end{array}$ & $\begin{array}{l}\text { Search strategy identi- } \\
\text { fied poster presentation. } \\
\text { Author contacted and } \\
\text { provided research thesis. } \\
\text { The focus group identi- } \\
\text { fied } 4 \text { themes but did } \\
\text { not provide illustrations } \\
\text { to support the partici- } \\
\text { pant voice. Therefore no } \\
\text { findings were extracted }\end{array}$ \\
\hline
\end{tabular}




\begin{tabular}{|c|c|c|c|c|c|c|}
\hline \multicolumn{7}{|c|}{ (Continued) } \\
\hline Author/ year & $\begin{array}{l}\text { Methodology/ } \\
\text { Method }\end{array}$ & $\begin{array}{l}\text { Phenomena } \\
\text { of interest }\end{array}$ & $\begin{array}{l}\text { Participants } \\
\text { Age } \\
\text { gender }\end{array}$ & $\begin{array}{l}\text { Sampling/Setting/Geog- } \\
\text { raphy/culture }\end{array}$ & Conclusions/Outcomes & Reviewer Notes \\
\hline $\begin{array}{l}\text { Ravenek, MJ. } \\
\text { Schneider MA. } \\
(2009)^{30}\end{array}$ & $\begin{array}{l}\text { Qualitative study: } \\
\text { Phenomenology } \\
\text { One to one semi- } \\
\text { structured inter- } \\
\text { views and field } \\
\text { notes. } \\
\text { Thematic analysis }\end{array}$ & $\begin{array}{l}\text { Focus: how social } \\
\text { support influences } \\
\text { PA participation as } \\
\text { perceived by pwPD } \\
\text { (early stages) } \\
\text { How perceived sup- } \\
\text { port interacts with } \\
\text { perception of con- } \\
\text { trol to influence this } \\
\text { participation }\end{array}$ & $\begin{array}{l}7 \text { people with PD ( } 3 \\
\text { female and } 4 \text { men) } \\
\text { Mean age } 52.1 \text { (SD } 4.9 \text { ) } \\
\text { Mean PD duration } 42 \\
\text { months (SD 25.7) } \\
\text { H\&Y: stage } 2 \\
\text { All were physically } \\
\text { active. }\end{array}$ & $\begin{array}{l}\text { Sampling: Purposive - } \\
\text { stage } 2 \text { (aged 45-60) } \\
\text { Setting: community. } \\
\text { Interview location: } \\
\text { research center } \\
\text { Geography: Canada } \\
\text { Cultural: not specified }\end{array}$ & $\begin{array}{l}\text { ICF model - environ- } \\
\text { ment factors (built and } \\
\text { natural environment, } \\
\text { products and technol- } \\
\text { ogy, ecotone issues, and } \\
\text { accessibility knowledge } \\
\text { and social support. } \\
3 \text { main types of support } \\
\text { (instrumental, emotion, } \\
\text { informational) had a } \\
\text { positive impact on PA } \\
\text { participation. } \\
\text { PA participation used as } \\
\text { a means to help control } \\
\text { progression of PD }\end{array}$ & $\begin{array}{l}\text { Only study that specifi- } \\
\text { cally addressed social } \\
\text { support for physical } \\
\text { activity. All findings } \\
\text { included as supported } \\
\text { by illustrations }\end{array}$ \\
\hline $\begin{array}{l}\text { Sheehy, TL. } \\
(2014)^{49}\end{array}$ & $\begin{array}{l}\text { Semi-structured } \\
\text { interviews face to } \\
\text { face }(2 \text { inter- } \\
\text { viewers) audio- } \\
\text { transcribed. } \\
\text { Follow up inter- } \\
\text { view: } 3 \text { months } \\
\text { later via phone } \\
(\mathrm{n}=17) \text { or at the } \\
\text { program's gym } \\
(\mathrm{n}=2) \text { for member } \\
\text { checking/follow up } \\
\text { questions post } \\
\text { analysis (data dealt } \\
\text { with as previous } \\
\text { and included into } \\
\text { analysis) } \\
\text { Analysis: IPA } \\
\text { NVivo to store and } \\
\text { organize data }\end{array}$ & $\begin{array}{l}\text { Focus: experience of } \\
\text { social relationships, } \\
\text { physical self-percep- } \\
\text { tions and posttrau- } \\
\text { matic growth within } \\
\text { group PA }\end{array}$ & $\begin{array}{l}20 \text { people ( } 8 \text { males/ } 12 \\
\text { females) currently or } \\
\text { previous participants } \\
\text { non-contact boxing pro- } \\
\text { gram for pwPD (atten- } \\
\text { dance average } 4.15 \text { year } \\
\text { (SD 2.06) } \\
\text { Mean age } 85.6 \text { (SD } \\
6.47 \text { ) } \\
\text { Caucasians } \\
\text { Most had a postsecond- } \\
\text { ary degree or diploma } \\
\text { (n=17) } \\
\text { Time sign diagnosis = } \\
8.75 \text { (SD =7.94) } \\
\text { H\&Y: not stated }\end{array}$ & $\begin{array}{l}\text { Sampling: Purposive } \\
\text { (inclusion criteria - } \\
\text { English speaking partici- } \\
\text { pants in boxing pro- } \\
\text { gram) } \\
\text { Setting: community } \\
\text { Interview location: pro- } \\
\text { grams gym; public } \\
\text { library; university con- } \\
\text { ference room. } \\
\text { Geography: USA } \\
\text { Cultural: mono culture } \\
\text { (Caucasian) }\end{array}$ & $\begin{array}{l}\text { Themes }-5 \text { categories: } \\
\text { physical ability of parti- } \\
\text { cipants, psychological } \\
\text { challenges faced by par- } \\
\text { ticipants in the program, } \\
\text { social comparisons made } \\
\text { by participants to other } \\
\text { members; social support } \\
\text { between members and } \\
\text { trainer, and psychologi- } \\
\text { cal outcomes from being } \\
\text { in the program. }\end{array}$ & $\begin{array}{l}\text { Published Masters thesis. } \\
\text { Strong emphasis on } \\
\text { positionality and theo- } \\
\text { retical framework. Good } \\
\text { description of program. } \\
\text { All main themes used as } \\
\text { all were supported by } \\
\text { illustrative quotes. }\end{array}$ \\
\hline $\begin{array}{l}\text { Westheimer, O. } \\
\text { Mcrae, C Hench- } \\
\text { cliffe, C et al. } \\
(2015)^{55}\end{array}$ & $\begin{array}{l}\text { Mixed methods } \\
\text { design. } \\
\text { Quantitative mea- } \\
\text { sures and face-to- } \\
\text { face semi-struc- } \\
\text { tured interviews. } \\
\text { Audio recorded- } \\
\text { coding and catego- } \\
\text { rization } \\
\text { Thematic analysis }\end{array}$ & $\begin{array}{l}\text { Focus: participants } \\
\text { experiences of dance } \\
\text { class on QoL, } \\
\text { adherence, and } \\
\text { value of class }\end{array}$ & $\begin{array}{l}12 \text { people }(6 \mathrm{male} / 6 \\
\text { female) } \\
\text { Mean age } 66.2(\mathrm{SD}= \\
7.3) \\
\mathrm{H} \& \mathrm{Y}=1-4\end{array}$ & $\begin{array}{l}\text { Sampling: Convenience / } \\
\text { snowball sampling. } \\
\text { Recruited by neurologist } \\
\text { and other patients. } \\
\text { Inclusion criteria = aged } \\
\text { over 30, diagnosis of } \\
\text { PD. Mobile with or } \\
\text { without assistance, give } \\
\text { informed consent and } \\
\text { medical clearance. } \\
\text { Attended dance class } 16 \\
\text { session (8 weeks:20hrs) } \\
\text { Geography: USA } \\
\text { Multicultural (white/ } \\
\text { African American/His- } \\
\text { panic/Other) }\end{array}$ & $\begin{array}{l}\text { Interviews suggested } \\
\text { that the value was not } \\
\text { limited to physical func- } \\
\text { tioning. Benefits related } \\
\text { to QoL, and wellbeing } \\
\text { that were not reflected } \\
\text { in changes on quantita- } \\
\text { tive measures. } \\
\text { Supportive emotional } \\
\text { and social experience } \\
\text { along with PA appear to } \\
\text { have kept attendance } \\
\text { strong. }\end{array}$ & $\begin{array}{l}\text { Participants classified } \\
\text { into 'worse' or 'better' } \\
\text { based on changes to } \\
\text { objective measures } \\
\text { rather than themes. Very } \\
\text { difficult to extract quali- } \\
\text { tative data as this was } \\
\text { poorly presented with } \\
\text { little information with } \\
\text { regards to coding of } \\
\text { themes. Two findings } \\
\text { were extracted, and a } \\
\text { supporting illustration } \\
\text { was extracted from the } \\
\text { answers to the interview } \\
\text { questions presented in } \\
\text { table } 4 \text { and table } 5 \text {. }\end{array}$ \\
\hline
\end{tabular}

H\&Y, Hoehn and Yahr disease classification; QoL, Quality of life; IPA, interpretative phenomenological analysis; pwPD, people with Parkinson's disease; PD, Parkinson's disease; PA, physical activity; ICF, international classification of functioning, disability and health; PT, physiotherapist; RCT, randomized controlled trial. 
Appendix VI: List of study findings and illustrations

\begin{tabular}{|c|c|}
\hline Article Reference & $\begin{array}{l}\text { Bassett, S. Stewart, J. Giddings, L. (2012) Nordic walking versus ordinary } \\
\text { walking for people with Parkinson's disease: A single case design } 52\end{array}$ \\
\hline Finding & $\begin{array}{l}\text { Experience of the Nordic Walking program: The progressive manner in which the } \\
\text { walking phases were implemented gave the participant confidence with her } \\
\text { walking: }[\mathrm{U}]\end{array}$ \\
\hline Illustration & $\begin{array}{l}\text { "Starting on flat surfaces first, that are not near road traffic - like at the park and } \\
\text { university grounds, meant/could concentrate on Nordic walking; I didn't need to } \\
\text { think about where I was going.. That helped with my confidence so that I was } \\
\text { not distracted by all the road noises and people going past. After six weeks, I } \\
\text { became less conscious of the poles; I did not need to think all the time about how } \\
\text { to walk with them. The poles became an extension of my arms. Once I had } \\
\text { mastered all of what is involved, I found I was self-correcting and walking quite } \\
\text { confidently" participant p120 [U] }\end{array}$ \\
\hline Finding & $\begin{array}{l}\text { Experience of the Nordic Walking program: Walking with a designated person } \\
\text { enhanced commitment }[\mathrm{U}]\end{array}$ \\
\hline Illustration & $\begin{array}{l}\text { "I think having a commitment to meet someone at a specific planned time was } \\
\text { most important. Let's face it; what I really felt like doing some mornings was to } \\
\text { stay in bed! It would have been easy to make excuses to myself if I did not know } \\
\text { I had to meet you." Participant pg } 120[\mathrm{U}]\end{array}$ \\
\hline Finding & $\begin{array}{l}\text { General health: Participant noted that over the Nordic walking phase, changes } \\
\text { occurred in her general wellbeing especially with her appetite, sleep and energy } \\
\text { levels. [U] }\end{array}$ \\
\hline Illustration & $\begin{array}{l}\text { "After a couple of weeks of Nordic walking I actually felt hungry again!... I } \\
\text { hadn't realized that I had not felt that for a while. I had been worried about } \\
\text { having to use sedatives to sleep. A few weeks into the program... I cut my dose } \\
\text { and found I was able to get back to sleep after waking in the night." participant } \\
\text { p120 [U] }\end{array}$ \\
\hline Finding & $\begin{array}{l}\text { Physical and psychological wellbeing: When using the poles the participant found } \\
\text { she could overcome some of her physical and psychological limitations [U] }\end{array}$ \\
\hline Illustration & $\begin{array}{l}\text { "The poles opened up my world again. I am not so overwhelmed on social } \\
\text { occasions. I used to hesitate going where I knew there was going to be a crowd - } \\
\text { especially if there was a possibility that there would not be seats provided. Now I } \\
\text { just take my poles and use them as supports and that helps." Participant pg } 120 \\
\text { [U] }\end{array}$ \\
\hline Article Reference & $\begin{array}{l}\text { Bognar, S., Defaria, AM. O'Dywer, C et al. (2017) More than just dancing: } \\
\text { experiences of people with Parkinson's disease in a therapeutic dance program. }{ }^{59}\end{array}$ \\
\hline Finding & $\begin{array}{l}\text { Connecting through dance: the need for socialization was articulated as a central } \\
\text { motivator for attending class, as participants admitted that living with PD could } \\
\text { be isolating. [U] }\end{array}$ \\
\hline
\end{tabular}




\begin{tabular}{|c|c|}
\hline Illustration & $\begin{array}{l}\text { "When you get a Parkinson's diagnosis, [you] tend to back into a cage somewhere } \\
\text { where nobody can see my weaknesses. You tend to exclude yourself from society. } \\
\text { When you join something like Dancing with Parkinson's you become part of a } \\
\text { larger group and it's much easier to fight that weakness.... The other classmates } \\
\text { are a benefit that I didn't expect or think about at the time". [P9] pg } 3 \text { [U] }\end{array}$ \\
\hline Finding & $\begin{array}{l}\text { Redefining the self: seeking knowledge to become proficient in self-management } \\
{[\mathrm{U}]}\end{array}$ \\
\hline Illustration & $\begin{array}{l}\text { "Going to class you're not giving in - you're getting back. You're getting } \\
\text { something to help yourself." [P2] pg } 4[\mathrm{U}]\end{array}$ \\
\hline Finding & $\begin{array}{l}\text { Dance and the mind: Participants reported that the class provided opportunities } \\
\text { to coordinate their body in new ways and promoted use of different areas of the } \\
\text { brain. }[\mathrm{U}]\end{array}$ \\
\hline Illustration & $\begin{array}{l}\text { "[The brain] gets exercise at Dancing with Parkinson's because most dances are } \\
\text { more than one step... when they give me the second thing to do at the same } \\
\text { time... I notice it immediately." [P9] pg4 [U] }\end{array}$ \\
\hline Finding & $\begin{array}{l}\text { Dance and the body: participants reported a desire to maintain their current } \\
\text { functional status and to slow physical deterioration as motivation for continued } \\
\text { participation [C] }\end{array}$ \\
\hline Illustration & $\begin{array}{l}\text { "It has led to some fluidity, which might not have been there in the body earlier." } \\
{[\mathrm{P} 1] \text { pg4 [C] }}\end{array}$ \\
\hline Finding & $\begin{array}{l}\text { The emotional experience: participants agreed that attending the dance class } \\
\text { improved their mood. [U] }\end{array}$ \\
\hline Illustration & $\begin{array}{l}\text { "”. you grab a partner and go around, and she smiles, but can't speak and she's } \\
\text { happy. Emotionally it affects me as well because it's my benefit to make her } \\
\text { happy." [P8] pg } 4 \text { [U] }\end{array}$ \\
\hline Article Reference & $\begin{array}{l}\text { Crizzle, AM., Newhouse, IJ. (2012) Themes associated with exercise adherence in } \\
\text { persons with Parkinson's disease: A qualitative study }{ }^{5}\end{array}$ \\
\hline Finding & $\begin{array}{l}\text { Reassurance from instructor: was an important motivator of exercise adherence. } \\
{[\mathrm{U}]}\end{array}$ \\
\hline Illustration & $\begin{array}{l}\text { P4 "A few people started off better than me... and that bothered me. But the } \\
\text { instructor told me not to worry about it and that I should work at my own pace. } \\
\text { I didn't think I could do it. I nearly gave up. But the leader always insisted that I } \\
\text { could do it, so I had to prove myself and then I could."pg180 [U] }\end{array}$ \\
\hline Finding & $\begin{array}{l}\text { Group structure and group support: participants reported developing a good } \\
\text { rapport with each other over time and were encouraged by the improvements } \\
\text { made in their physical and social abilities. [C] }\end{array}$ \\
\hline Illustration & $\begin{array}{l}\text { Participant } 1 \text { said (pointing to participant 4): "He actually talked to me later on, } \\
\text { at the beginning he just sat there completely mum"pg180 [C] }\end{array}$ \\
\hline Finding & $\begin{array}{l}\text { Improved psychological wellbeing from perceived physical benefits: Participants } \\
\text { noted improvement in their normal everyday activities. [U] }\end{array}$ \\
\hline
\end{tabular}




\begin{tabular}{|c|c|}
\hline Illustration & $\begin{array}{l}\text { Participant } 1 \text { "I find it so much easier to reach for items in shelves that I had } \\
\text { difficulty getting to before. I can also cut my meat and vegetables better. I feel } \\
\text { like I can put more pressure on the knife. Such little things, but these play a big } \\
\text { part of my daily living. I can't' believe these things can be improved just by } \\
\text { exercising." P1 pg180 [U] }\end{array}$ \\
\hline Article Reference & $\begin{array}{l}\text { Davis, JT. Erbart, A. Trcinski, BH et al. }{ }^{(2003)} \text { Variability of experiences for } \\
\text { individuals living with Parkinson disease. }\end{array}$ \\
\hline Finding & $\begin{array}{l}\text { Physical limitations and compensatory strategies: participants shared similar } \\
\text { physical limitation related to PD, however, the way in which these limitations } \\
\text { affected each participant was unique. [U] }\end{array}$ \\
\hline Illustration & $\begin{array}{l}\text { "With this disease you have similarities; you know they are just similar and at } \\
\text { other times it's like your disease is custom made to you.". Participant pg } 40 \text { [U] }\end{array}$ \\
\hline Finding & $\begin{array}{l}\text { Falls: Issues pertaining to falls included their unique experience of falling, how } \\
\text { falls have impacted their life and measure they have taken to prevent future falls. } \\
{[\mathrm{U}]}\end{array}$ \\
\hline Illustration & $\begin{array}{l}\text { "I think balance is probably for me the worst thing... I've had one fall, but I'll } \\
\text { remember that "til they bury me, that sudden realization of what happened. } \\
\text { Fortunately, I was in my bedroom and fell on the nice carpeted floor, but it was a } \\
\text { hell of a sensation." participant pg } 40[\mathrm{U}]\end{array}$ \\
\hline Finding & $\begin{array}{l}\text { Walking: Participants identified } 4 \text { specific symptoms that affected their ability to } \\
\text { walk; difficulty initiating movement, shuffling, festinating gait and freezing. [U] }\end{array}$ \\
\hline Illustration & $\begin{array}{l}\text { "It affects the first step I take, the second and third steps are a lot easier than the } \\
\text { first step. So if get pointed in the right direction, and I get moving, I can continue } \\
\text { moving but that first step can be a real challenge sometimes."pg40 [U] }\end{array}$ \\
\hline Finding & $\begin{array}{l}\text { Functional mobility: Participants identified additional areas that were problem- } \\
\text { atic; decreased mobility in bed; transfers from sit to stand as well as solutions. } \\
{[\mathrm{U}]}\end{array}$ \\
\hline Illustration & $\begin{array}{l}\text { "Moving around in bed is almost an impossibility. There seems to be so much } \\
\text { resistance between the sheets and it just seems impossible." participant pg40 [U] }\end{array}$ \\
\hline Finding & $\begin{array}{l}\text { Medication cycles were recognized as a leading contributor to participants' } \\
\text { physical limitations. [U] }\end{array}$ \\
\hline Illustration & $\begin{array}{l}\text { "I notice my problems walking are dependent on my medication ... I skip my } \\
\text { medication, my balance gets bad, I lose my stride, and feel very uncomfortable } \\
\text { walking." P pg41 [U] }\end{array}$ \\
\hline Finding & $\begin{array}{l}\text { Altering performance of activity of daily living: participants managed ADLs by } \\
\text { altering how they were achieved including; increased time and being organized } \\
\text { [C] }\end{array}$ \\
\hline Illustration & $\begin{array}{l}\text { "Some participants acknowledged organizing and taking advantage of the } \\
\text { productive time when their medication was 'on'. Example of preparation were } \\
\text { writing out checks before going to the store and organizing commonly used areas } \\
\text { into workstations that were equipped with frequently needed items." (author page } \\
\text { 41) [C] }\end{array}$ \\
\hline
\end{tabular}




\begin{tabular}{|c|c|}
\hline Finding & $\begin{array}{l}\text { Participants identified coping with the disease through maintaining a positive } \\
\text { outlook. [U] }\end{array}$ \\
\hline Illustration & $\begin{array}{l}\text { "Every once in a while I think, 'hey, I'm lucky I have Parkinson's', I have friends } \\
\text { who have had lung problems, who have had heart attacks, total loss of vision and } \\
\text { are buried. We are alive." P pg41 [U] }\end{array}$ \\
\hline Finding & $\begin{array}{l}\text { Participants coped with the disease by attempting to maintain a sense of } \\
\text { normalcy. [C] }\end{array}$ \\
\hline Illustration & $\begin{array}{l}\text { "One participant explained how she hid her foot, which showed dyskinesia, under } \\
\text { the desk, to prevent co-workers from discovering that she had PD." (author pg } \\
\text { 41) [C] }\end{array}$ \\
\hline Finding & Being a self-advocate was a method of dealing with the disease. [U] \\
\hline Illustration & $\begin{array}{l}\text { "Unless you are lucky enough to have a nurse practitioner like - - or you find a } \\
\text { good physical therapist, you have to be an advocate, you have to say 'I want } \\
\text { physical therapy, what can you write me a prescription for? I want to go and be } \\
\text { evaluated about how to use a car or I want to learn about how to get my oxygen } \\
\text { better'... so I feel that you have to gather information, you have to be an } \\
\text { advocate and tell them what you want and hope that you have a good circle of } \\
\text { family and friends". Pg } 42 \text { [U] }\end{array}$ \\
\hline Finding & $\begin{array}{l}\text { Health Care issues: the current health care system does not meet the comprehen- } \\
\text { sive needs of individuals with PD. [U] }\end{array}$ \\
\hline Illustration & $\begin{array}{l}\text { "it's kind of pitiful that we don't have outreach with physical therapy, we have } \\
\text { no national, state or local outreach programs, look at the table of us, how much } \\
\text { we would improve if we had one hour of outreach a week." pg42 [U] }\end{array}$ \\
\hline Article Reference & $\begin{array}{l}\text { Erikson, BM. Arne, M. Ahlgren, C (2013) Keep moving to retain the healthy self: } \\
\text { the meaning of physical exercise in individuals with Parkinson's disease. }{ }^{44}\end{array}$ \\
\hline Finding & $\begin{array}{l}\text { Being Part of life: participants expressed an aim to continue to participate in } \\
\text { valuable areas of life even if support was needed for managing to do so. [C] }\end{array}$ \\
\hline Illustration & $\begin{array}{l}\text { "When you aren't disabled... you think that it's the practical things which are... } \\
\text { the main thing, but it isn't. It's how you feel inside... and then... then it's not } \\
\text { such a big defeat if you can't get your shoes on. What I mean with being part of } \\
\text { life, it's probably to be needed." [C] }\end{array}$ \\
\hline Finding & $\begin{array}{l}\text { Trusting own experiences: meant being attentive to the signals from one's body, } \\
\text { and acting in the best way according to one's knowledge, beliefs and experiences. } \\
{[\mathrm{C}]}\end{array}$ \\
\hline Illustration & $\begin{array}{l}\text { “... I keep myself a bit busy at home... I have recorded a lot of tunes ... and do } \\
\text { certain exercise there... and so on. So ... I rarely sit still... if I put it that way." } \\
\text { Participant pg } 2240 \text { [C] }\end{array}$ \\
\hline Finding & $\begin{array}{l}\text { Identifying oneself as physically active: related to the participant definition of } \\
\text { themselves as a physical active person both in the past and in the present [U] }\end{array}$ \\
\hline
\end{tabular}




\begin{tabular}{|c|c|}
\hline Illustration & $\begin{array}{l}\text { "... one was out running and doing aerobics and ... such things. I used to } \\
\text { participate in those gymnastic displays we had at that time... and that was fun... } \\
\text { of course that was a driving force... () and there the habit too ... (to exercise)." } \\
\text { participant pg } 2240[\mathrm{U}]\end{array}$ \\
\hline Finding & $\begin{array}{l}\text { Taking responsibility for own health: generated from the decision making that } \\
\text { preceded start to exercise and included the decision to believe in the good effect } \\
\text { of exercise and the counteracting effective of a passive lifestyle [C] }\end{array}$ \\
\hline Illustration & $\begin{array}{l}\text { ".. and then its only making the best of the situation... one mustn't think } \\
\text { negatively, one has to try to avoid that... think positively, try turning everything } \\
\text { into the best instead." Participant pg } 2241 \text { [C] }\end{array}$ \\
\hline Finding & $\begin{array}{l}\text { Have to keep on moving: was a driving force for exercise, emanating from } \\
\text { sustaining self-image, believing in the benefits of keeping oneself active was the } \\
\text { underlying construct }[\mathrm{U}]\end{array}$ \\
\hline Illustration & $\begin{array}{l}\text { "And... then it's my goal to try to keep myself ...keep myself on the go as long as } \\
\text { possible so that I ... yes, to be part of life. Not only to sit on a park-bench and } \\
\ldots \text {..hear somebody talk ... but ... to be active as well as I can..." participant pg } \\
2241[\mathrm{U}]\end{array}$ \\
\hline Finding & $\begin{array}{l}\text { One should see to one's health: a knowledge-driven obligation towards oneself } \\
\text { and toward supportive significant others and health professional, that exercise is } \\
\text { necessary to good health. }[\mathrm{U}]\end{array}$ \\
\hline Illustration & $\begin{array}{l}\text { "One tried to do (exercise) as well as one can in everything and ... doesn't try to } \\
\text { waste time in any way but tries to do as well as possible. ... because the doctor } \\
\text { said that ... exercise is very important for everybody ... for everybody who has } \\
\text { Parkinson's disease... so I mustn't become an idler so ... out and ... yes walk a lot } \\
\text { with poles to keep up the agility in arms and shoulders." Participant pg } 2241 \text { [U] }\end{array}$ \\
\hline Finding & $\begin{array}{l}\text { Experience wellbeing through accomplishing: focused on an aspect of wellbeing } \\
\text { that derived from the satisfaction of the achievements in itself }[\mathrm{U}]\end{array}$ \\
\hline Illustration & $\begin{array}{l}\text { "... the body feels good, he say "oh, it's so good that you've done this" and so } \\
\text { on and ... it's difficult to say what it is but... I think I feel very good when I've } \\
\text { achieved something." Participant pf } 2242[\mathrm{U}]\end{array}$ \\
\hline Finding & $\begin{array}{l}\text { Having feelings of coherence: The achievement of attending an exercise program } \\
\text { and having support by the regularity and the promoting of the program were } \\
\text { important facilitating factors for those participants. [U] }\end{array}$ \\
\hline Illustration & $\begin{array}{l}\text { "I thinks it's very good with that hour that... at least once a week gets... the } \\
\text { muscles there and there ... and do something.... I feel satisfaction by being able } \\
\text { to participate... that is the primary thing, I think. And ... also to feel that the } \\
\text { body manages, because... I somethings think when we're exercising, that we are } \\
\text { incredibly capable considering our capacity. And sometimes you're not capable at } \\
\text { all, but ... then when you experience that "Oh god, I can do this" then you get a } \\
\text { kick..." participant pg } 2242 \text { [U] }\end{array}$ \\
\hline Article Reference & $\begin{array}{l}\text { Hammarlund, CS. Anderson K. Anderson, M. et al. (2014) The significance of } \\
\text { walking from the perspective of people with Parkinson's disease. }{ }^{8}\end{array}$ \\
\hline
\end{tabular}




\begin{tabular}{|c|c|}
\hline Finding & $\begin{array}{l}\text { Changed walking ability: participants described gait had become slower, they } \\
\text { were dragging their feet or steps could be tripping and the feet could get stuck to } \\
\text { the ground. [U] }\end{array}$ \\
\hline Illustration & $\begin{array}{l}\text { "So .... I felt like I sort of walked and dragged a little on .... a little like an old } \\
\text { man, sort of dragged my feet." participant pg } 659[\mathrm{U}]\end{array}$ \\
\hline Finding & $\begin{array}{l}\text { Emotional reactions: Walking difficulties were perceived as aggravating and } \\
\text { problematic, causing feelings of sadness and hopelessness. Struggling with } \\
\text { activities resulted in frustration and anger. [U] }\end{array}$ \\
\hline Illustration & $\begin{array}{l}\text { "It's draining your energy and it saddens me. You become angry with yourself } \\
\text { when it's hard and things don't work as you want them to. When you do } \\
\text { something, things that you've done a hundred times before with ease, take forever } \\
\text { to do today." participant pg } 659 \text { [U] }\end{array}$ \\
\hline Finding & $\begin{array}{l}\text { Strategies to manage the impact of walking difficulties: They chose to accept the } \\
\text { new situation, to plan their lives in both the long and short term, using cognitive } \\
\text { strategies to overcome difficulties. [U] }\end{array}$ \\
\hline Illustration & $\begin{array}{l}\text { "if I know that I am doing something special then I have to adjust my medication } \\
\text { accordingly. And you have to constantly think, think ahead, plan a little more of } \\
\text { your activities in relation to the medication and so.... It has clearly changed my } \\
\text { life, it really has..." participant pg } 659[\mathrm{U}]\end{array}$ \\
\hline Finding & $\begin{array}{l}\text { Social consequences: Walking difficulties had an impact on the ability to } \\
\text { participate in social activities within or outside the family. [U] }\end{array}$ \\
\hline Illustration & $\begin{array}{l}\text { “... it changes the whole lifestyle. You don't want to be amongst others. You } \\
\text { back away from being in a crowd ... and at various events one feels like an } \\
\text { outsider. I simply can't keep up anymore, not like I used to.” participant pg } 660 \\
\text { [U] }\end{array}$ \\
\hline Finding & $\begin{array}{l}\text { Independence and Integrity: Participants felt that the ability to walk was } \\
\text { important in managing their daily activities and work and was central to } \\
\text { participation in life like everyone else. [U] }\end{array}$ \\
\hline Illustration & $\begin{array}{l}\text { "Being mobile, to be able to participate in life normally, to be able to move } \\
\text { around, take the train, drive the car... to be able to walk to different things } \\
\text { without any trouble." Participant pg } 660[\mathrm{U}]\end{array}$ \\
\hline Article Reference & $\begin{array}{l}\text { Hislop, J. Gray, S. Melling, S. et al. (2015) An exploration of physical activity } \\
\text { experiences in people with Parkinson's disease. }\end{array}$ \\
\hline Finding & Confidence building: Attendance at the group helped build confidence [U] \\
\hline Illustration & $\begin{array}{l}\text { "It gives you more confidence to go out in the world and tackle life. You know, } \\
\text { if you've got a wee network of people that understand you..." participant pg } 3 \\
{[\mathrm{U}]}\end{array}$ \\
\hline Article Reference & $\begin{array}{l}\text { Houston, S. McGill A. Lee, R. et al. (2015) English-National-Ballet-Dance-for- } \\
\text { Parkinson's. An Investigative Study 2. A report on a three year mixed methods- } \\
\text { research-study. }{ }^{47}\end{array}$ \\
\hline
\end{tabular}




\begin{tabular}{|c|c|}
\hline Finding & $\begin{array}{l}\text { Fluency of movement: participants have a perception that music helps people to } \\
\text { move in a more fluid and coordinated fashion. [U] }\end{array}$ \\
\hline Illustration & $\begin{array}{l}\text { "The dance made me feel more graceful, moving and flowing with the music, it } \\
\text { made me feel that I had to move when the music started." P pg } 19[\mathrm{U}]\end{array}$ \\
\hline Finding & $\begin{array}{l}\text { Balance and stability: Participants have mentioned an improved sense of body } \\
\text { awareness both inside and outside of the dance studio with participants also } \\
\text { noting a lack of freezing. [U] }\end{array}$ \\
\hline Illustration & $\begin{array}{l}\text { "I get a bit of freezing in movement, but I feel I'm less freezing when I come to } \\
\text { class. I don't freeze here and when I go back home I don't freeze as often that } \\
\text { day." P pg } 22[\mathrm{U}]\end{array}$ \\
\hline Finding & $\begin{array}{l}\text { Posture: Participants note the challenge in maintaining posture in relation to } \\
\text { dance and the difficulties in maintaining posture outside of the class in order to } \\
\text { cause permanent change }[U]\end{array}$ \\
\hline Illustration & $\begin{array}{l}\text { "I think when I go off and I remember to walk so tall, and keep my head up, and } \\
\text { swing my arms, just to do movement, and if I think I go dancing and sit up } \\
\text { straight, and shoulders back, head up, it's a great image to hold on to." } \\
\text { Participant pg } 22[\mathrm{U}]\end{array}$ \\
\hline Finding & $\begin{array}{l}\text { Progression of Parkinson's: Participants noted that the physical changes may not } \\
\text { be as obvious or distinctive as the mental benefits. [U] }\end{array}$ \\
\hline Illustration & $\begin{array}{l}\text { "It's not just I'm in the mood, but physically I feel different. I don't think about } \\
\text { it all the time, but suddenly I realize how much better I feel. More movement, } \\
\text { more energy, certainly more energized....I want to stay positive and not think } \\
\text { about Parkinson's." Participant pg } 24 \text { [U] }\end{array}$ \\
\hline Finding & $\begin{array}{l}\text { Cognitive Functioning: Participants find the dance classes to be quite difficult } \\
\text { with respect to remembering the movement sequences and being able to move } \\
\text { different parts of the body simultaneously. [C] }\end{array}$ \\
\hline Illustration & $\begin{array}{l}\text { "I do think it is good for you. The whole mental activity is on a different plane } \\
\text { from physical activity." Participant pg } 25[\mathrm{C}]\end{array}$ \\
\hline Finding & $\begin{array}{l}\text { Participant expressed what was important to them personally in maintaining a } \\
\text { good quality of life }[C]\end{array}$ \\
\hline Illustration & $\begin{array}{l}\text { "Having confidence to do things/having the ability to keep doing interesting } \\
\text { activities /having movement capability and stability/being around loved ones/ } \\
\text { having a religious belief." Author pg } 25[\mathrm{C}]\end{array}$ \\
\hline Finding & $\begin{array}{l}\text { Aid to daily life: Participants noted how exercise from class help to alleviate } \\
\text { rigidity and pain and improve mobility for everyday activities.[U] }\end{array}$ \\
\hline Illustration & $\begin{array}{l}\text { "It is typically a matter of identifying the right exercises on each occasion to } \\
\text { alleviate the various neuro-muscular afflictions. For my shoulder I noted during } \\
\text { the classes that the 'lasso, arrow and sword' provided some temporary relief - so, } \\
\text { I used a similar routine at home to improve mobility and it seems to work better } \\
\text { than anything else I have tried (e.g. stretching and strengthening)." participant pg } \\
26[\mathrm{U}]\end{array}$ \\
\hline
\end{tabular}




\begin{tabular}{|c|c|}
\hline Finding & $\begin{array}{l}\text { Motivation to keep coming to the English National Ballet ENB Dance for } \\
\text { Parkinson's program were diverse. [U] }\end{array}$ \\
\hline Illustration & $\begin{array}{l}\text { "I didn't know anyone with Parkinson's before I came to these classes. I was all } \\
\text { alone. It's not just about dancing, it's making friends and sharing." P pg } 27 \text { [U] }\end{array}$ \\
\hline Article Reference & $\begin{array}{l}\text { Jones, D. Rochester, L. Birleson, A. et al. (2008) Everyday walking with } \\
\text { Parkinson's disease: understanding personal challenges and strategies. }{ }^{50}\end{array}$ \\
\hline Finding & $\begin{array}{l}\text { Walking whilst- walking while doing something else: participants noted that } \\
\text { undertaking dual tasks could become challenging. [U] }\end{array}$ \\
\hline Illustration & $\begin{array}{l}\text { "Sometimes if I concentrate too much on not spilling the tea I sort of forget about } \\
\text { going up the stairs ... It's as if my nervous system is overloaded. Can't } \\
\text { unscramble the two messages." (P17 pg 9) [U] }\end{array}$ \\
\hline Finding & $\begin{array}{l}\text { Walking 'in' - walking in different environments: outdoors posed unpredictable } \\
\text { challenges and were disliked. Indoors doorways and furniture, the need to } \\
\text { constantly change direction and to change positions caused the main challenges. } \\
{[\mathrm{U}]}\end{array}$ \\
\hline Illustration & $\begin{array}{l}\text { "Having to stop, start and change direction; being jostled; coping with } \\
\text { distractions; feeling pressured and self-conscious; and having to concentrate on } \\
\text { yourself and others, were all tiring and often frightening." (author pg 10) [U] }\end{array}$ \\
\hline Finding & $\begin{array}{l}\text { Walking 'after' - walking following another activity: Participants noted an } \\
\text { increased difficulty in walking after a activity }[\mathrm{C}]\end{array}$ \\
\hline Illustration & $\begin{array}{l}\text { "Increasingly maneuvering out of dining chairs at a table; rolling to the edge of } \\
\text { the bed in order to get the legs over the edge; exiting the bath; turning after } \\
\text { standing were reported as challenging, especially in the 'off' state. Initial walking } \\
\text { after all these activities was likely to be characterized by shuffling steps, } \\
\text { potentially stooped posture, often accompanied by unsteadiness..." (author pg } \\
\text { 11) [C] }\end{array}$ \\
\hline Finding & $\begin{array}{l}\text { Monitoring: walking using concentration: Participants needed to monitor walking } \\
\text { quality and consciously correct deficits. [U] }\end{array}$ \\
\hline Illustration & $\begin{array}{l}\text { "...but I'm always watching, thinking, terrified of falling over but there's that } \\
\text { feeling always that you must watch where you are going." }(05) . \operatorname{Pg} 12[\mathrm{U}]\end{array}$ \\
\hline Finding & $\begin{array}{l}\text { Correcting: Walking through generating rhythm and size of steps. Imagined or } \\
\text { actual visual input was used to start and maintain stepping and overcoming } \\
\text { freezing. }[\mathrm{U}]\end{array}$ \\
\hline Illustration & $\begin{array}{l}\text { "I had to rehearse mentally if I was going to take a step and then take the step." } \\
\text { (20). Pg } 13[\mathrm{U}]\end{array}$ \\
\hline Article Reference & $\begin{array}{l}\text { Khalil, H. Nazzal, M. Al-Sheyab, N. (2016) Parkinson's disease in Jordan: } \\
\text { Barriers and motivators to exercise. }{ }^{57}\end{array}$ \\
\hline Finding & $\begin{array}{l}\text { Difficulty of diagnosis: Participants with PD reported spending a huge chunk of } \\
\text { time searching for a basic answer that can justify their symptoms: a diagnosis. [U] }\end{array}$ \\
\hline
\end{tabular}




\begin{tabular}{|c|c|}
\hline Illustration & $\begin{array}{l}\text { "I started to feel symptoms } 6 \text { years ago but I have only been diagnosed } 2 \text { years } \\
\text { later. I was complaining of general slowness of movement and fatigue; simple } \\
\text { things would become difficult. The GP excluded PD as it did not fit with my age } \\
\text { category, However I doubted it was PD, as the symptoms were similar to my } \\
\text { father's, who is also a PD patient. When other symptoms started to appear like } \\
\text { tremor, the GP decided to refer me to a specialized neurologist" P5 pg } 512 \text { [U] }\end{array}$ \\
\hline Finding & $\begin{array}{l}\text { Lack of informational support by neurologist: about the importance of exercise or } \\
\text { physiotherapy to their condition. }[\mathrm{U}]\end{array}$ \\
\hline Illustration & $\begin{array}{l}\text { "I do not do any specific exercises for managing my condition as I am not aware } \\
\text { of any... my neurologist has not mentioned this to me." P9 pg } 513[\mathrm{U}]\end{array}$ \\
\hline Finding & $\begin{array}{l}\text { Lack of referrals to physiotherapy: None of the participants were referred to } \\
\text { physiotherapy for explicit management of PD. [U] }\end{array}$ \\
\hline Illustration & $\begin{array}{l}\text { "Four years ago I was complaining from lumbar disk and for that reason I've } \\
\text { been referred to physiotherapy. The treatment was for my back pain but not for } \\
\text { the PD." P3 pg } 514[\mathrm{U}]\end{array}$ \\
\hline Finding & $\begin{array}{l}\text { Disease-specific issues: such as stiffness and fatigue may limit their potential } \\
\text { participation in future exercise programs. }[\mathrm{C}]\end{array}$ \\
\hline Illustration & $\begin{array}{l}\text { "All the participants reported experiencing the "wearing off" phenomenon in } \\
\text { which these symptoms become much more apparent." Author pg } 514 \text { [C] }\end{array}$ \\
\hline Finding & $\begin{array}{l}\text { Setting-related issues: location of the exercise was considered important for the } \\
\text { participants to engage in an exercise program with some preferring home and } \\
\text { others hospital [C] }\end{array}$ \\
\hline Illustration & $\begin{array}{l}\text { "The commitment to the program will be better if it is at the hospital and under } \\
\text { the supervision of a therapist. At home, you may get busy with other stuff; defer } \\
\text { the exercises and end- up of not doing them." P1 pg } 514 \text { [C] }\end{array}$ \\
\hline Finding & $\begin{array}{l}\text { Outcome expectations: positively affect the participant's decision about getting } \\
\text { engaged in a future exercise program [U] }\end{array}$ \\
\hline Illustration & $\begin{array}{l}\text { "My health is my priority and if exercise would help then I will exercise daily. I } \\
\text { really would like to reach that level of doing things by my own and not relying } \\
\text { on others; this is all what I want." P4 pg } 515[\mathrm{U}]\end{array}$ \\
\hline Finding & $\begin{array}{l}\text { Family support: and commitment was perceived as an important element for some } \\
\text { participants to initiate and maintain an exercise program. [U] }\end{array}$ \\
\hline Illustration & $\begin{array}{l}\text { "Family has always been a source of support for me to accept the disease and to } \\
\text { deal with it. A lot of mornings I would be very tired sitting on my sofa or lying in } \\
\text { my bed until my son comes and asks me to go for a walk with him. His } \\
\text { encouragement pulls me up and it's just about the start that is difficult then I get } \\
\text { clicked on; I usually feel much better afterwards." P9 pg } 515 \text { [U] }\end{array}$ \\
\hline Article Reference & $\begin{array}{l}\text { Khalil, H. Busse, M. Quin, L et al. (2017) A pilot study of a minimally supervised } \\
\text { home exercise and walking program for people with Parkinson's disease in } \\
\text { Jordan. }{ }^{6}\end{array}$ \\
\hline
\end{tabular}




\begin{tabular}{|c|c|}
\hline Finding & $\begin{array}{l}\text { Enablers: Participants reported that DVD was very clear, easy to follow and } \\
\text { provided an important tool to continue performing the exercises independently at } \\
\text { home }[\mathrm{U}]\end{array}$ \\
\hline Illustration & $\begin{array}{l}\text { "The DVD was simple and easy to follow its use at home was a strong motivator } \\
\text { to continue doing the exercises." (table } 4 \text { no page no.) [U] }\end{array}$ \\
\hline Finding & $\begin{array}{l}\text { Perceived improvement: whether in physical or mental status was a key to } \\
\text { motivate them to adhere to the exercise program [C] }\end{array}$ \\
\hline Illustration & $\begin{array}{l}\text { "The exercise program has affected me both mentally and physically before I got } \\
\text { to know you and was introduced to this program I used to lock myself away at } \\
\text { home fear of falling was a big issue. I was therefore not moving ... Now my } \\
\text { mobility has improved dramatically ... I feel as If I have regained big chunk of } \\
\text { my life." (table 4) [C] }\end{array}$ \\
\hline Finding & $\begin{array}{l}\text { Participants report that compensation for transportation helped with adherence } \\
{[\mathrm{U}]}\end{array}$ \\
\hline Illustration & $\begin{array}{l}\text { "As you know I come from a distance and my participation would have been } \\
\text { impossible without covering the transportation costs that was really important } \\
\text { aspect." (table 4) [U] }\end{array}$ \\
\hline Finding & $\begin{array}{l}\text { Continuous monitoring: Participants perceived the importance of initial instruc- } \\
\text { tional sessions and the weekly phone calls as important elements for initial } \\
\text { adoption of the program and also for continuation; they were perceived as } \\
\text { important aspects of the program to build self-efficacy [C] }\end{array}$ \\
\hline Illustration & $\begin{array}{l}\text { "I really prefer doing the exercises at home ... the sessions with therapist were } \\
\text { very important to know what I am supposed to do and to build confidence." } \\
\text { (table } 4 \text { no page no.) [C] }\end{array}$ \\
\hline Finding & $\begin{array}{l}\text { Social interaction and relation with the therapist: was a strong motivator to } \\
\text { adhere to the program. [U] }\end{array}$ \\
\hline Illustration & $\begin{array}{l}\text { "For the first time ever I felt that someone was truly taking care of me that was } \\
\text { the best piece of the intervention. It made me feel in turn that I should take care } \\
\text { of myself by committing to the exercise program. The therapist was an excellent } \\
\text { motivator." (table } 4 \text { no page no.) [U] }\end{array}$ \\
\hline Finding & $\begin{array}{l}\text { Family support: encouragement provided by family members was perceived to be } \\
\text { important. [U] }\end{array}$ \\
\hline Illustration & $\begin{array}{l}\text { "The family encouragement was very important for me to take this step and start } \\
\text { the exercise program with you." (table } 4 \text { no page no.) [U] }\end{array}$ \\
\hline Finding & $\begin{array}{l}\text { Personal challenges: comorbidities such as knee or hip osteoarthritis, cervical or } \\
\text { lumbar disk, limited but did not prevent them from engaging in the exercise } \\
\text { program. }[\mathrm{U}\}\end{array}$ \\
\hline Illustration & $\begin{array}{l}\text { "I have a chronic problem in my knee and some of the balance exercises were } \\
\text { causing me more pain ... this did not stop me from doing the exercise ... the } \\
\text { therapist helped me in modifying the exercise so that it became more tolerable." } \\
\text { (table } 4 \text { no page no.) }[\mathrm{U}]\end{array}$ \\
\hline
\end{tabular}




\begin{tabular}{|c|c|}
\hline Finding & $\begin{array}{l}\text { Participants perceived that Physical fatigue would limit but not prevent them from } \\
\text { engaging in the exercise program. [U] }\end{array}$ \\
\hline Illustration & $\begin{array}{l}\text { "I lacked the habit of past exercise. This is the first time I have been in a } \\
\text { structured program. When I first started, I used to feel tired even after performing } \\
\text { only a few movements. This feeling, however, ceased off after few weeks." [U] }\end{array}$ \\
\hline Finding & $\begin{array}{l}\text { Depression: affected motivation to do anything including getting engaged in the } \\
\text { exercise program. [U] }\end{array}$ \\
\hline Illustration & $\begin{array}{l}\text { "Since I've been diagnosed with PD and I felt low...I became less motivated to } \\
\text { do anything in life ... even when you invited me to do the exercises I felt } \\
\text { apathetic." (table } 4 \text { no page no.) [U] }\end{array}$ \\
\hline Finding & $\begin{array}{l}\text { Lack of outcome expectations: one participant at early stage believed he was not } \\
\text { necessarily in need for exercise as they were still physically fit. [C] }\end{array}$ \\
\hline Illustration & $\begin{array}{l}\text { "I feel I am physically better than other people... and the nature of my work } \\
\text { requires a lot of movements. I work as a plumber; hence I move all the time." } \\
\text { (table } 4 \text { no page no.) [C] }\end{array}$ \\
\hline Finding & $\begin{array}{l}\text { Denial of PD diagnosis: participants at early stage were still in doubt of being } \\
\text { diagnosed of PD. [U] }\end{array}$ \\
\hline Illustration & $\begin{array}{l}\text { "I did not do the exercises because I am still not convinced I have PD ... I have } \\
\text { this dilemma ... I am really not convinced that I have PD ... next week I will be } \\
\text { seeing another neurologist to discuss my case." (table } 4 \text { no page no.) [U] }\end{array}$ \\
\hline Finding & Cultural challenges: being active is not the norm particularly for old people. [U] \\
\hline Illustration & $\begin{array}{l}\text { "At home I have the fear that my sons will comment on this I am trying to avoid } \\
\text { this. I did though all the sessions with the therapist in the clinic but did not do } \\
\text { the sessions at home." (table } 4 \text { no page no.) [U] }\end{array}$ \\
\hline Article Reference & $\begin{array}{l}\text { Kunkel, D. Robinson, J. Fitton, C et al. (2017) It takes two: the influence of } \\
\text { dance partners on the perceived enjoyment and benefits during participation in } \\
\text { partnered ballroom dance classes for people with Parkinson's. }\end{array}$ \\
\hline Finding & $\begin{array}{l}\text { Views on the experience on being partnered with their spouse or volunteer: } \\
\text { participants who danced with their spouse or somebody else they knew well, } \\
\text { appreciated not only the practical convenience but also the sense of "moral } \\
\text { support" and shared enjoyment that this afforded them. [U] }\end{array}$ \\
\hline Illustration & $\begin{array}{l}\text { Person with Parkinson's: “I wouldn't have liked, I wouldn't have gone if } \\
\text { [husband] hadn't have been my partner I don't think. I liked that very much, I } \\
\text { liked it a lot." [Brenda: F, age 81, BLOCK 3] [U] }\end{array}$ \\
\hline Finding & $\begin{array}{l}\text { Managing potential sources of tension or difficulty: It was potentially problem- } \\
\text { atic, both for novice and experienced dancing couples, when a male dancer with } \\
\text { Parkinson's found it difficult to fulfil the traditional role that was expected of } \\
\text { him. [U] }\end{array}$ \\
\hline Illustration & $\begin{array}{l}\text { Person with Parkinson's: "She irritated me to the extent that I said "Look I'm } \\
\text { supposed to be leading here!" and she said "Yes, but you're not doing it right!" } \\
\text { [laughing] Andrew age } 73 \text { H\&Y3 block 1) pg } 5 \text { [U] }\end{array}$ \\
\hline
\end{tabular}




\begin{tabular}{|c|c|}
\hline Finding & $\begin{array}{l}\text { Views on continuing with dance classes: all people with Parkinson's expressed an } \\
\text { interest in continuing to dance but none had made firm arrangements to do so. } \\
{[\mathrm{U}]}\end{array}$ \\
\hline Illustration & $\begin{array}{l}\text { Person with Parkinson's: "I think it, because I can't walk that far, and I can't } \\
\text { walk that quickly, certainly regular dancing would take the place of some of the } \\
\text { walking that I can't do." Elizabeth: age } 71, \mathrm{H} \& Y 2 \text {, pg } 6[\mathrm{U}]\end{array}$ \\
\hline Article Reference & $\begin{array}{l}\text { O'Brien, C. Clemson, L. Caning CG. (2016) Multiple factors, including non- } \\
\text { motor impairments, influence decision making with regard to exercise participa- } \\
\text { tion in Parkinson's disease: a qualitative enquiry. }\end{array}$ \\
\hline Finding & $\begin{array}{l}\text { Loss of ability and loss of identity as active self: Participants identified a variety } \\
\text { of physical and mental changes attributable to both PD and ageing that caused } \\
\text { reduced ability to engage in physical activities and consequently led to adaptations } \\
\text { in the way they participated in them. [U] }\end{array}$ \\
\hline Illustration & $\begin{array}{l}\text { "It's just the limitations of not being able to do things you used to be able to do. } \\
\text { You move into a stage where you can't do things that you used to be able to do } \\
\text { and I miss very much not having a license to drive a car and so I'm sort of } \\
\text { housebound except for my wife, my wife drives me places but it's hard on her } \\
\text { too, so it's a hard time." P7 pg } 3 \text { [U] }\end{array}$ \\
\hline Finding & $\begin{array}{l}\text { Focusing on not losing more: adapting to loss of physical ability also involved } \\
\text { focusing on what participants could do and trying to prevent further losses. [U] }\end{array}$ \\
\hline Illustration & $\begin{array}{l}\text { "I'm just trying to hold on to what I have. I mean I am quite old. I really felt that } \\
\text { I must not overburden the body." P2 pg } 4[\mathrm{U}]\end{array}$ \\
\hline Finding & $\begin{array}{l}\text { Facing challenges of apathy, fatigue and other health problems were a significant } \\
\text { barrier to regular exercise participation. }[\mathrm{U}]\end{array}$ \\
\hline Illustration & "You've got to battle with willpower all the time." P3 pg 5 [U] \\
\hline Finding & $\begin{array}{l}\text { Relationships with a shared understanding: Participants valued the experience of } \\
\text { exercising with others with PD. Having a common purpose and a shared } \\
\text { understanding were common themes. [U] }\end{array}$ \\
\hline Illustration & $\begin{array}{l}\text { "It's not that you want sympathy but understanding. So, when you're down there } \\
\text { (referring to the group) I actually totally relax because we are all understanding } \\
\text { each other." P2 pg6 [U] }\end{array}$ \\
\hline Finding & $\begin{array}{l}\text { Comparing oneself with others in the exercise group: was another aspect of } \\
\text { exercising in a group of people with PD.[U] }\end{array}$ \\
\hline Illustration & $\begin{array}{l}\text { "That was an incentive for me to put more into it because I could see that one } \\
\text { guy in particular was benefitting from it." P6 pg } 6[\mathrm{U}]\end{array}$ \\
\hline Finding & $\begin{array}{l}\text { Identifying goals: participants had their own individual goals, therefore each } \\
\text { participant had different goals and expectations from the program and these were } \\
\text { often different from the physiotherapists' goals. [C] }\end{array}$ \\
\hline Illustration & $\begin{array}{l}\text { "I believe that at my stage of Parkinson's progress that I have to be concerned } \\
\text { about power and balance." P6 Pg } 6[\mathrm{C}]\end{array}$ \\
\hline
\end{tabular}




\begin{tabular}{|c|c|}
\hline Finding & $\begin{array}{l}\text { Evaluating if expectations are met: and the outcome of this evaluation was } \\
\text { continually changing. [C] }\end{array}$ \\
\hline Illustration & $\begin{array}{l}\text { "You can get disappointed if you can't do it. P1 The effort really means a lot, but } \\
\text { I just sort of glided it through somehow to get it finished ... I didn't do it to my } \\
\text { satisfaction." P3 pg } 6[\mathrm{C}]\end{array}$ \\
\hline Article Reference & $\begin{array}{l}\text { O’Brien, M. Dodd, KJ. Bilney, B (2008) A qualitative analysis of a progressive } \\
\text { resistance exercise program for people with Parkinson's disease. }{ }^{46}\end{array}$ \\
\hline Finding & $\begin{array}{l}\text { Motivators for participation were broader than just physical outcomes: they gave } \\
\text { a number of reasons for why they chose to take part in the study [C] }\end{array}$ \\
\hline Illustration & $\begin{array}{l}\text { Participant } 1: \text { " }[\mathrm{I}] \text { was keen to try and assist the program as a participant for the } \\
\text { sake of future generations of PD sufferers." Pg } 1353[\mathrm{C}]\end{array}$ \\
\hline Finding & $\begin{array}{l}\text { The outcomes were broader than just physical outcomes: participants said that } \\
\text { there were no significant physical gains, yet they commented favorably about } \\
\text { their experiences. }[\mathrm{U}]\end{array}$ \\
\hline Illustration & $\begin{array}{l}\text { Participant } 8 \text { said: "I haven't noticed anything physically; maybe just a marginal } \\
\text { improvement in the strength of my arms. With regard to my legs, I don't think } \\
\text { there has been much change at all, but mentally I think, oh I don't know, I think } \\
\text { just being involved with other people sort of, even at this level, helps me a bit." } \\
\text { Pg } 1354 \text { [U] }\end{array}$ \\
\hline Finding & $\begin{array}{l}\text { Indicators of success for participants varied: Participants said they used several } \\
\text { methods to judge whether they were progressing in the program or not. [U] }\end{array}$ \\
\hline Illustration & $\begin{array}{l}\text { "I did feel that I was working as I went through the bands, the stronger bands, } \\
\text { that, yeah, it did seem to get easier as I went along, particularly with the legs. } \\
\text { Much easier." (Participant 12), pg } 1354[\mathrm{U}]\end{array}$ \\
\hline Finding & $\begin{array}{l}\text { The participants' experience of a disease-specific exercise program was positive: } \\
\text { Benefits included sharing information about Parkinson's disease. [U] }\end{array}$ \\
\hline Illustration & $\begin{array}{l}\text { "[We] exchanged thoughts and notes that we had we all seem to have been on } \\
\text { the Internet at various stages, gathering information, and it was very helpful."” } \\
\text { (Participant 4). Pg } 1355[\mathrm{U}]\end{array}$ \\
\hline Article Reference & $\begin{array}{l}\text { Pretzer-Aboff, I. Galik, E. Resnick B. (2009) Parkinson's disease: barriers and } \\
\text { facilitators to optimizing function. }\end{array}$ \\
\hline Finding & $\begin{array}{l}\text { Personality components: Participants spoke of personality traits that promoted } \\
\text { independence in physical activities such as resilience, determination, need for } \\
\text { independence, denial of need for assistance, and humor. [U] }\end{array}$ \\
\hline Illustration & $\begin{array}{l}\text { "I don't ever call for help, really. I try to stay independent." Participant no pg no. } \\
{[\mathrm{U}]}\end{array}$ \\
\hline Finding & $\begin{array}{l}\text { Physiological symptoms: both motor and non-motor, of PD were noted by people } \\
\text { with PD to limit the ability to engage in physical and functional activities. [U] }\end{array}$ \\
\hline Illustration & $\begin{array}{l}\text { Another participant described his experience with bradykinesia: "It is difficult. I } \\
\text { muddle through.... It takes me forever... my speeds have gone from slow and } \\
\text { stop." (no page no.) [U] }\end{array}$ \\
\hline
\end{tabular}




\begin{tabular}{|c|c|}
\hline Finding & $\begin{array}{l}\text { Communication Difficulties: Difficulty writing and speaking because of tremor, } \\
\text { hypophonia, and freeze episodes were described as hampering the ability to } \\
\text { communicate with others. [U] }\end{array}$ \\
\hline Illustration & $\begin{array}{l}\text { "I cannot write. There is a stack of condolence letters here, from when my wife } \\
\text { died. I initially said I will answer each of them myself. I had all the intentions of } \\
\text { doing so, but I couldn't write. So I decided that I could do it all with a machine, } \\
\text { on the computer. But I couldn't do it on the computer because I couldn't type } \\
\text { either. Now I can't hit the right key for nothing." No pg no. [U] }\end{array}$ \\
\hline Finding & $\begin{array}{l}\text { Environmental Factors: including the social support network, members of the } \\
\text { healthcare team, and the physical environment were identified as either facilitating } \\
\text { or challenging the person's day-to-day ability to function [C] }\end{array}$ \\
\hline Illustration & $\begin{array}{l}\text { "Participants noticed that small spaces, clutter, and stairs decreased mobility." } \\
\text { Author no page no. [C] }\end{array}$ \\
\hline Article Reference & $\begin{array}{l}\text { Quinn, L. Busse, M. Khalil H. et al. (2010) Client and therapist views on exercise } \\
\text { programs for early-mid stage Parkinson's disease and Huntington's disease. }{ }^{56}\end{array}$ \\
\hline Finding & $\begin{array}{l}\text { Disease specific barriers: Participants with PD, highlighted several factors, namely } \\
\text { stiffness, fatigue and problems with maintaining concentration. [U] }\end{array}$ \\
\hline Illustration & $\begin{array}{l}\text { PD5: "Having the disease does influence my ability to exercise, because I think it } \\
\text { is hard to concentrate. So focusing is difficult and also the tiredness and fatigue is } \\
\text { another problem." pg } 922[\mathrm{U}]\end{array}$ \\
\hline Finding & Lack of information on exercise in PD [U] \\
\hline Illustration & $\begin{array}{l}\text { "I had not any advice as to exercises. We picked up some leaflets at one time in } \\
\text { the doctor's surgery, from the PD society, but I don't think there was anything in } \\
\text { there that referred to specific exercises or something that was relevant to me." } \\
\text { Participant pg } 922[\mathrm{U}]\end{array}$ \\
\hline Finding & $\begin{array}{l}\text { Barrier: location of exercise Lifestyle issues: Alternatively, some of the clients } \\
\text { preferred doing exercises at home rather than going to the gym, because it would } \\
\text { fit better with their lifestyle.[U] }\end{array}$ \\
\hline Illustration & $\begin{array}{l}\text { PD2: "I tend to exercise at home rather than going to the gym because it fits in } \\
\text { with my lifestyle really. At the weekend I have my granddaughter and also I am } \\
\text { working three times a week." Table III pg } 922[\mathrm{U}]\end{array}$ \\
\hline Finding & Benefits of group exercise. [U] \\
\hline Illustration & $\begin{array}{l}\text { PD4: "I think if you want to do the exercise by yourself, it will be very difficult } \\
\text { to motivate yourself. If you were in a class which is not necessarily a class of } \\
\text { Parkinson's but a class of people in the same fitness range as you and it is } \\
\text { organized in a daily or weekly basis, you can along with it. There is the social } \\
\text { aspect as well." table III pg } 922 \text { [U] }\end{array}$ \\
\hline Finding & $\begin{array}{l}\text { Setting targets and having knowledge of benefits of exercise: Clients felt that their } \\
\text { understanding of the relevance and usefulness of exercises was most critical to } \\
\text { determining whether or not they participated. [U] }\end{array}$ \\
\hline
\end{tabular}




\begin{tabular}{|c|c|}
\hline Illustration & $\begin{array}{l}\text { PD5: "I think it should be clear how the exercises fit into the program. That's } \\
\text { helpful. If I feel that the exercises make a difference, then I can do them more. } \\
\text { Also having the general idea of the benefits of doing the exercise. I think the } \\
\text { exercise is good for me and by doing the exercise I appreciate that there is a } \\
\text { difference." Table III pg } 923 \text { [U] }\end{array}$ \\
\hline Finding & Simplicity of exercise program [U] \\
\hline Illustration & $\begin{array}{l}\text { PD5: "Sessions with physiotherapy actually taking me through with the exercises; } \\
\text { that is good I think. They gave me exercises to do at home but I have not } \\
\text { continued using them because of a couple of things actually. For back exercises } \\
\text { there was no standard to do them. So, you do a lot and a lot of exercises like the } \\
\text { hand behind the shoulder or the hand in front but actually you do not know what } \\
\text { for the exercises are and the differences are tricky.... I think exercises should be } \\
\text { simple and clear how they fit into the program. That's helpful." Table III p923 } \\
\text { [U] }\end{array}$ \\
\hline Article Reference & $\begin{array}{l}\text { Ravenek, MJ. Schneider MA. (2009) Social support for physical activity and } \\
\text { perceptions of control in early Parkinson's disease. }{ }^{30}\end{array}$ \\
\hline Finding & $\begin{array}{l}\text { Sources of support: Family members - the most salient forms of support provided } \\
\text { by participants' families were instrumental and emotional support. [U] }\end{array}$ \\
\hline Illustration & $\begin{array}{l}\text { "They encourage me, goad me, embarrass me into doing some [activities] and } \\
\text { they also will alter their activities to accommodate me which is very good. [My } \\
\text { husband] just you know, like he always is trying to get me into doing more. He } \\
\text { probably encourages me and gets me going more than I would do myself." Pg } \\
1929 \text { [U] }\end{array}$ \\
\hline Finding & $\begin{array}{l}\text { Sources of support: Friends - The main forms of instrumental support were the } \\
\text { provision of transportation and mutual participation in physical activity. [U] }\end{array}$ \\
\hline Illustration & $\begin{array}{l}\text { "They'll come out and walk with me sometimes or friends will come out and bike } \\
\text { with me... it's nice to have friends who are compassionate, and ah understand } \\
\text { what you are going through." Participant pg } 1930[\mathrm{U}]\end{array}$ \\
\hline Finding & $\begin{array}{l}\text { Sources of support: People in the workplace - This type of support commonly } \\
\text { took the form of organizing work schedules to allow for time to participate in } \\
\text { specific exercise programs. [U] }\end{array}$ \\
\hline Illustration & $\begin{array}{l}\text { "They were all very supportive because I started [exercising at the research center] } \\
\text { when I was still working. So, they all made sure, no matter who was working } \\
\text { with me, that I got off in time." P pg } 1930[\mathrm{U}]\end{array}$ \\
\hline Finding & $\begin{array}{l}\text { Physicians: participants' reports on GPs and neurologists was the lack of support } \\
\text { provided with regards to physical activity participation. [U] }\end{array}$ \\
\hline Illustration & $\begin{array}{l}\text { “'My] GP really didn't say much. Actually, neither doctor really encouraged } \\
\text { [physical activity]. They didn't discourage it, but they didn't really come out and } \\
\text { say, 'You should join this,' or 'You should do that.' There's probably a little bit } \\
\text { more work that could be done there to keep people active.” Participant pg } 1931 \\
\text { [U] }\end{array}$ \\
\hline
\end{tabular}




\begin{tabular}{|c|c|}
\hline Finding & $\begin{array}{l}\text { Social support groups: An important factor contributing to the perceived } \\
\text { suitability of these groups for participants was the variability in disease } \\
\text { progression of group members. When participants were not able to relate to other } \\
\text { group members, the support groups were seen as negative and this led to attrition. } \\
\text { When participants were able to relate to other group members, these groups } \\
\text { offered a tremendous amount of support. [U] }\end{array}$ \\
\hline Illustration & $\begin{array}{l}\text { "I went a couple times [to a support group] but they're all, I hate to say it, quite } \\
\text { elderly and that for me personally is very depressing... They're all a lot worse } \\
\text { because they've had it longer so they're very few young people.... So, we went to } \\
\text { the social group but it's like being at a senior's centre... so I haven't gone } \\
\text { after.... It is really depressing to see what you have to look forward to } \\
\text { becoming." Participant Pg } 1932 \text { [U] }\end{array}$ \\
\hline Finding & $\begin{array}{l}\text { Perceptions of control: participants viewed physical activity as a means to slow } \\
\text { the progression of the disease, and help maintain their independence [U] }\end{array}$ \\
\hline Illustration & $\begin{array}{l}\text { "I have no other answers with this, with this disease... it's something I want to } \\
\text { try and fight... and I don't know how to fight it [pause]. I don't want to be } \\
\text { overmedicated. I'm hoping exercise can flatline it or slow down the progression } \\
\text { or help me. I don't know. So, it's mainly my decision to [participate in physical } \\
\text { activity]." Participant pg } 1933 \text { [U] }\end{array}$ \\
\hline Article Reference & $\begin{array}{l}\text { Sheehy, TL. (2014) The Parkinson's experience of group physical activity- } \\
\text { Understanding social support, social comparison, physical self-perceptions, and } \\
\text { post-traumatic growth. }{ }^{49}\end{array}$ \\
\hline Finding & $\begin{array}{l}\text { Physical ability: participants identified improvements in physical competence post } \\
\text { program }[C]\end{array}$ \\
\hline Illustration & $\begin{array}{l}\text { "I wanted to do everything I could to delay, I think, keep active and delay if, if } \\
\text { possible any progression." (Fiona) participant page } 32[\mathrm{C}]\end{array}$ \\
\hline Finding & $\begin{array}{l}\text { Psychological challenges: participants feared doing a program which was unfamil- } \\
\text { iar and where they may hurt themselves [U] }\end{array}$ \\
\hline Illustration & $\begin{array}{l}\text { "I had all those kind of fears. Well, you know, what if it's like one of those } \\
\text { classes you go into and the person at the front is saying, no pain, no gain, and } \\
\text { you hurt yourself and then you can't do anything." (Imelda) pg } 32 \text { [U] }\end{array}$ \\
\hline Finding & $\begin{array}{l}\text { Social comparison: made with others varied based on disease and ability and } \\
\text { resulted in both positive and negative emotions [U] }\end{array}$ \\
\hline Illustration & $\begin{array}{l}\text { "When you talk to other people then, that have been doin' this, like, [Marty] for } \\
\text { thirteen years and she's in my class and they're doin' better than me, much better } \\
\text { than me...I think, we'll see, you know, there's a good possibility that thirteen } \\
\text { years from now I might be where I am." (Belle) pg } 33 \text { [U] }\end{array}$ \\
\hline Finding & $\begin{array}{l}\text { Social support: centered around the varied types of support given and received by } \\
\text { participants }[\mathrm{C}]\end{array}$ \\
\hline Illustration & $\begin{array}{l}\text { "I just kinda take it upon my, you know, if I see somebody not doin' what they, } \\
\text { you know, need to be doin' or goin' in the wrong direction, I, I just feel like I } \\
\text { should help." (Albert) pg34 [C] }\end{array}$ \\
\hline
\end{tabular}




\begin{tabular}{|c|c|}
\hline Finding & $\begin{array}{l}\text { Psychological outcomes: being in the program and improving physical competence } \\
\text { allowed participants to express surprise at their ability and a newfound confidence } \\
\text { and realization that they have new possibilities. [U] }\end{array}$ \\
\hline Illustration & $\begin{array}{l}\text { "It just gives you an all over good feeling that you can, you can do it and, uh, I } \\
\text { would never have thought, before I had the Parkinson's, that I could do anything } \\
\text { like this." (Silvia) pg } 35 .[\mathrm{U}]\end{array}$ \\
\hline Article Reference & $\begin{array}{l}\text { Westheimer, O. Mcrae, C Henchcliffe, C et al. (2015) Dance for PD: a } \\
\text { preliminary investigation of effects on motor function and quality of life among } \\
\text { persons with Parkinson's disease (PD). }{ }^{55}\end{array}$ \\
\hline Finding & Physical social and emotional benefits of the group [C] \\
\hline Illustration & $\begin{array}{l}\text { "Very positive communal experience; pleased to see improvements in others." } \\
\text { participant pg1266 [C] }\end{array}$ \\
\hline Finding & $\begin{array}{l}\text { The participants reported benefits related to QOL and wellbeing that were not } \\
\text { reflected in changes on quantitative measures. [C] }\end{array}$ \\
\hline Illustration & "Less helpless; doing something to help myself" [C] \\
\hline
\end{tabular}

